\title{
Dinoflagellate Contributions to the Deep Sea
}

\author{
Barrie Dale and Amy L. Dale
}

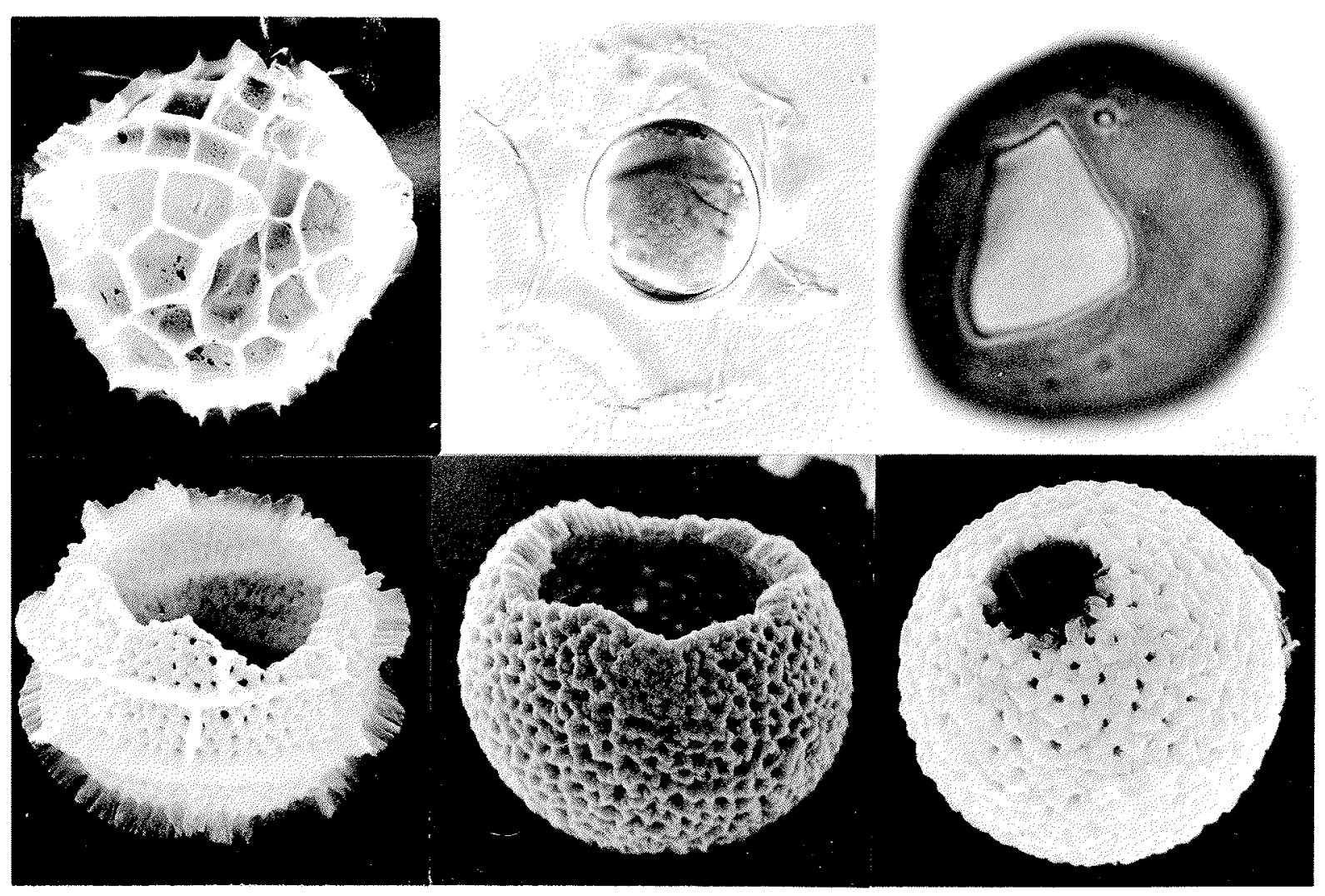

Woods Hole Oceanographic Institution

Woods Hole Massachusetts 02543

U.S.A

Ocean Biocoenosis Series No. 5 


\title{
Dinoflagellate Contributions to the Deep Sea
}

\author{
Barrie Dale and Amy L. Dale \\ Department of Geology \\ University of Olso \\ Norway
}

\author{
Edited by \\ Susumu Honjo \\ Woods Hole Oceanographic Institution \\ Woods Hole Massachusetts 02543 \\ U.S.A \\ Ocean Biocoenosis Series No. 5 \\ 1992
}


Ocean Biocoenosis Series No. 5

Woods Hole Oceanographic Institution, Woods Hole, MA 02543

(C) 1992 by the Woods Hole Oceanographic Institution. All rights reserved.

Published 1992

Printed in the United States of America

Availability: Office of the Research Librarian

Woods Hole Oceanographic Institution

Woods Hole, Massachusetts 02543

U.S.A.

$\$ 10.00$ U.S.

ISBN 1-880224-04-6

Explanation of Cover Photo: Dinoflagellate remains from deep sea sediment traps. Top left, Protoceratium areolatum theca from Station $\mathrm{PB}_{1}$ in the Panama Basin, $667 \mathrm{~m}$; top center, Impagidinium pallidum cyst from the Greenland Basin station (GB) in the Nordic Seas, $2,823 \mathrm{~m}$; top right, Protoperidinium conicoides cyst from bottom sediment at Station $\mathrm{S}$ in the Central North Atlantic, $5,581 \mathrm{~m}$; bottom left, Calciodinellum operosum cyst from Station $\mathrm{P}_{1}$ in the Central Pacific, $3,000 \mathrm{~m}$; bottom center, Thoracosphaera albatrosiana sensu Fütterer cyst from Station E in the Equatorial Atlantic, $988 \mathrm{~m}$; bottom right, Thoracosphaera heimii from Station $\mathrm{P}_{1}$ in the Central Pacific, 3,000 $\mathrm{m}$. The top center and top right are light photomicrographs; others are SEM micrographs. Magnifications are included in the text. 


\section{Contents}

\section{Dinoflagellate Contributions to the Open Ocean Sediment Flux -}

Barrie Dale 1

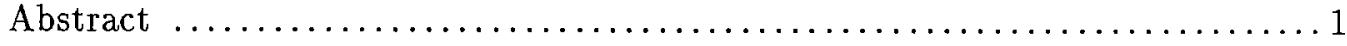

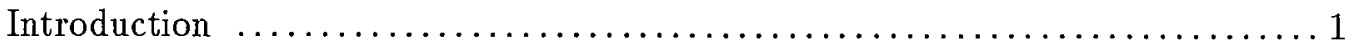

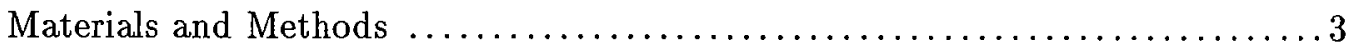

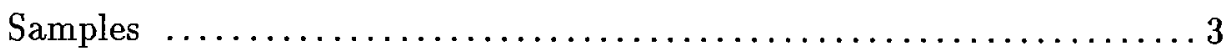

Sample Preparation and Examination $\ldots \ldots \ldots \ldots \ldots \ldots \ldots \ldots \ldots \ldots$

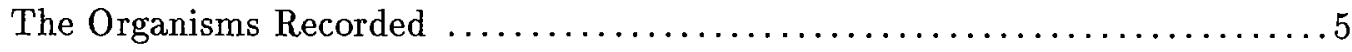

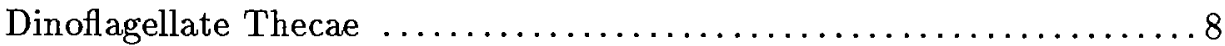

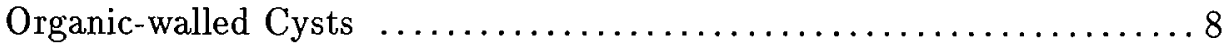

Calcareous Cysts .........................................

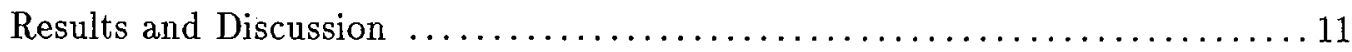

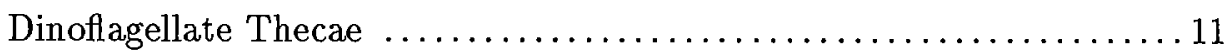

Dinoflagellate Cysts .................................... 12

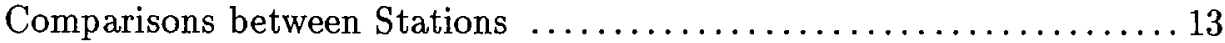

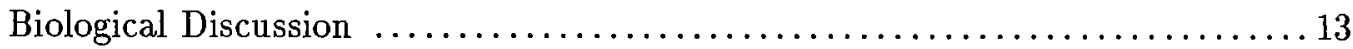

Comparison between Oceanic Cysts and Neritic Cysts ............ 14

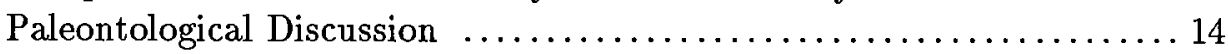

Comparison between Cysts from Sediment Traps and Cyst Assemblages from Deep-Sea Bottom Sediments .................... 15

The Supply of Cysts to Deep-Sea Sediments ................... 16

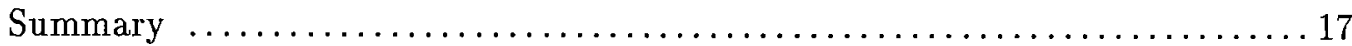

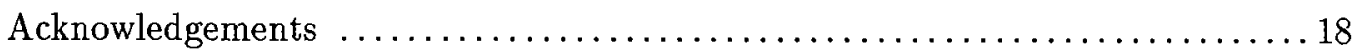

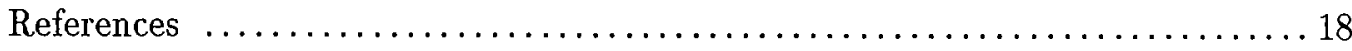

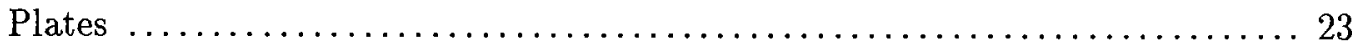

2 Thoracosphaerids: Pelagic Fluxes - Barrie Dale 33

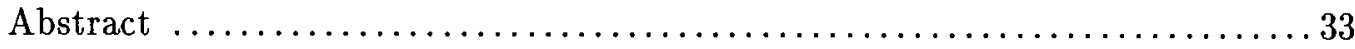

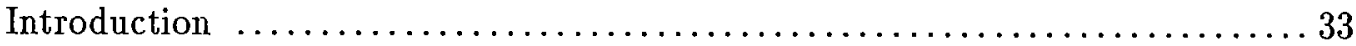

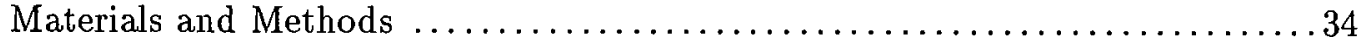

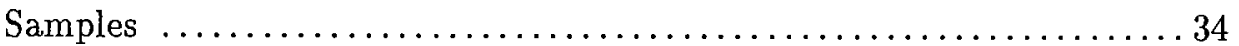

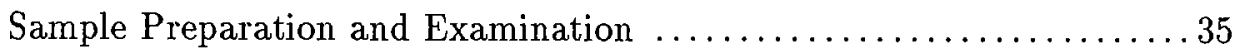

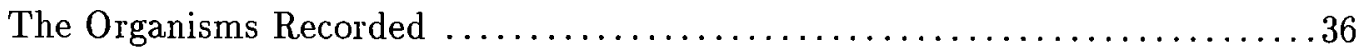

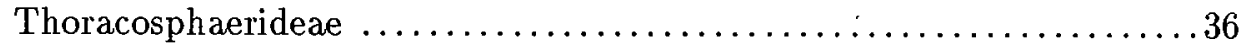




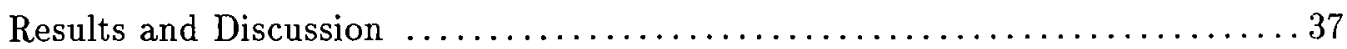

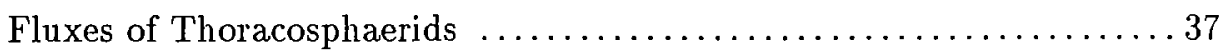

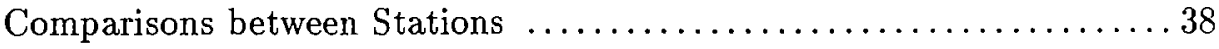

Phylogeny of the Morphology of Thoracosphaerids $\ldots \ldots \ldots \ldots \ldots \ldots \ldots \ldots$

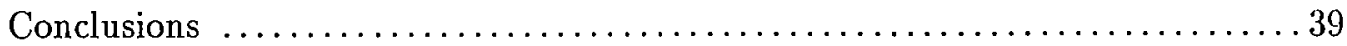

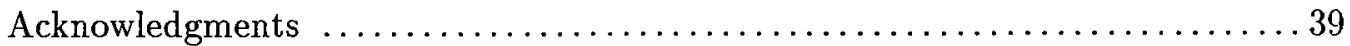

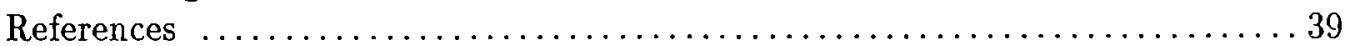

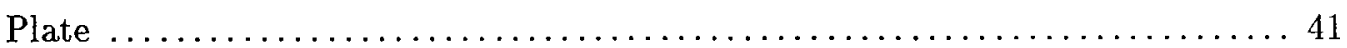

3 Dinoflagellate Contributions to the Sediment Flux of the Nordic Seas Amy L. Dale and Barrie Dale $\mathbf{4 5}$

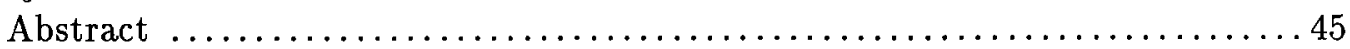

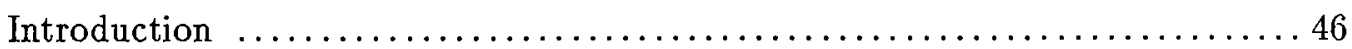

Materials and Methods .................................... 48

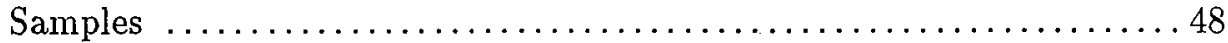

Sample Preparation and Examination $\ldots \ldots \ldots \ldots \ldots \ldots \ldots \ldots \ldots \ldots . \ldots \ldots$

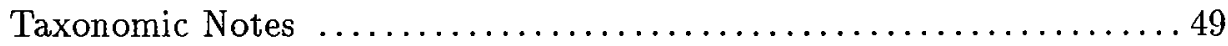

Treatment of Cyst Data ................................49

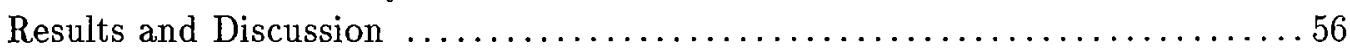

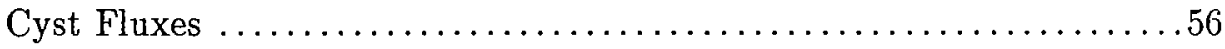

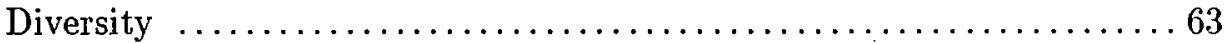

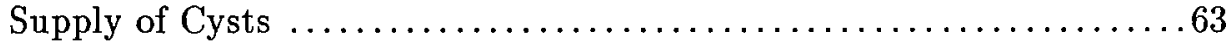

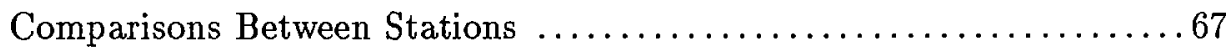

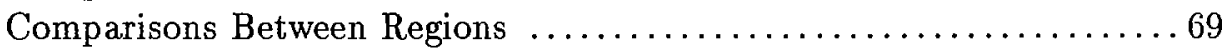

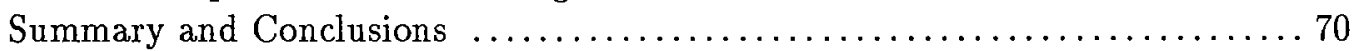

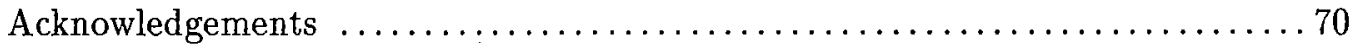

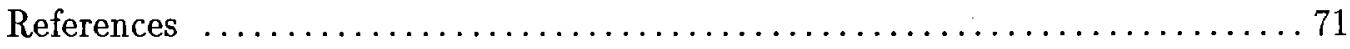

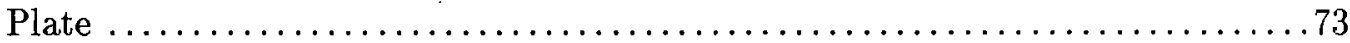




\section{List of Tables}

1.1 Summary of station data and samples used for deep sea dinoflagellate studies. 4

1.2 Fluxes of dinoflagellate thecae. . . . . . . . . . . . . 6

1.3 Fluxes of dinoflagellate cysts. . . . . . . . . . . . . 7

1.4 Dinoflagellate cyst assemblage in bottom sediment from Station S. . . . . . 9

2.1 Summary of station data and samples used for thoracosphaerid studies. . . 34

2.2 Fluxes of thoracosphaerids and total dinoflagellate cysts. . . . . . . . . 36

3.1 Station data for 7 sediment trap deployments in the Nordic Seas. . . . . . . 48

3.2 Percentage abundances and total number of cysts recorded for 5 sediment trap stations studied for dinoflagellate cysts. . . . . . . . . . . . . 50

3.3 Sampling intervals, total number of cysts seen, total cyst and sediment fluxes for the Aegir Ridge (NA) deployment (1985-1986) . . . . . . . . . . . . . 51

3.4 Sampling intervals, total number of cysts seen, total cyst and sediment fluxes for the Lofoten Basin (LB) deployment (1983-1984) . . . . . . . . . . . . . 52

3.5 Sampling intervals, total number of cysts seen, total cyst and sediment fluxes for the Bear Island (BI) deployment (1984-1985) . . . . . . . . . . . . . . . 53

3.6 Sampling intervals, total number of cysts seen, total cyst and sediment fluxes for the Fram Strait (FS) deployment (1984-1985). . . . . . . . . . . . . . . 54

3.7 Sampling intervals, total number of cysts seen, total cyst and sediment fluxes for the Greenland Basin (GB) deployment (1985-1986). . . . . . . . . . . . . 55

3.8 Comparison of average total sediment and total cyst fluxes for deep sea sediment trap stations in the Equatorial Atlantic Ocean, Central Pacific Ocean, Panama Basin, and Norwegian Atlantic and East Greenland Current regions of the Nordic Seas. . . . . . . . . . . . . . . . . . . . . 62

3.9 Correlation matrix of Pearson's Product Moment correlation coefficients for 5 sediment trap stations in the Nordic Seas, based on the percentage composition of their dinoflagellate cyst assemblages. . . . . . . . . . . . 67 
VI 


\section{List of Figures}

1.1 Location of PARFLUX sediment trap stations. . . . . . . . . . . . 4

3.1 Map of Nordic Seas region, showing locations of sediment trap stations used for cyst studies. . . . . . . . . . . . . . . . . . . 47

3.2 Cyst distribution for species representing $5 \%$ or more of the total assemblage at the Aegir Ridge (NA) station. . . . . . . . . . . . . . . . 51

3.3 Cyst distribution for species representing $5 \%$ or more of the total assemblage at the Lofoten Basin (LB) station. . . . . . . . . . . . . . . . . . 52

3.4 Cyst distribution for species representing $5 \%$ or more of the total assemblage at the Bear Island (BI) station. . . . . . . . . . . . . . . . . . 53

3.5 Cyst distribution for species representing $5 \%$ or more of the total assemblage at the Fram Strait (FS) station. . . . . . . . . . . . . . . . . . 54

3.6 Cyst distribution for species representing $5 \%$ or more of the total assemblage at the Greenland Basin (GB) station. . . . . . . . . . . . . . . . . 55

3.7 Average daily cyst fluxes at five stations compared. . . . . . . . . . . 56

3.8 Percentage cyst and total sediment fluxes at Aegir Ridge (NA) . . . . . . . 57

3.9 Percentage cyst and total sediment fluxes at Lofoten Basin (LB). . . . . . . 58

3.10 Percentage cyst and total sediment fluxes at Bear Island (BI) . . . . . . . . 59

3.11 Percentage cyst and total sediment fluxes at Fram Strait (FS). . . . . . . . 60

3.12 Percentage cyst and total sediment fluxes at Greenland Basin (GB). . . . . 61

3.13 Diagram of changing cyst assemblages around the Nordic Sea Basin, including cyst types that comprised $5 \%$ or more of the assemblage at any station. . . . 64

3.14 Cyst distribution at the Lofoten Basin station, showing sudden pulse of recycled pre-Quaternary (mainly Early Miocene) cysts in the July 2-August 1, 1984 , interval. . . . . . . . . . . . . . . . . . 66

3.15 Cluster dendrograms using Pearson Product Moment correlation coefficients for 19 cyst types at 5 stations in the Nordic Seas, plotted together with schematic representation of percentage abundance data. . . . . . . 68 


\title{
Chapter 1
}

\section{Dinoflagellate Contributions to the Open Ocean Sediment Flux}

\author{
Barrie Dale
}

\section{Abstract}

For the first time, sediment trap samples from several depths in the deep sea were analyzed to estimate both the types and amounts of mineral contributed by dinoflagellates to the deep sea sediment flux. Thecal remains of dinofiagellate motile stages were almost entirely restricted to the upper few hundred meters of the water column, supporting the generally accepted explanation of their absence in the fossil record (i.e., theca are composed of cellulosic material which is destroyed before they may be incorporated into bottom sediments). The main contribution to the sediment flux is composed of resting cysts routinely produced in the life cycles of just a few of the more obscure oceanic dinoflagellates, probably species of Scrippsiella or Ensiculifera. The cyst assemblage sedimenting out from plankton at present is overwhelmingly dominated by a few small calcareous types (up to several thousands $/ \mathrm{m}^{2} / \mathrm{day}$ ). If not dissolved, these may accumulate in paleontologically significant amounts in bottom sediments to give the most representative fossil record of oceanic dinoflagellates. "Oceanic assemblages" of organic-walled cysts from Recent deep-sea sediments previously described by palynologists probably represent long distance transport from more coastal regions rather than oceanic dinoflagellate production.

\section{Introduction}

Dinoflagellates are a major group of phytoplankton. They have been widely recorded from almost all present day aquatic environments, usually as characteristically biflagellated motile cells. These vegetative cells decay fairly rapidly after death and are not thought to fossilize. The extensive fossil record of dinoflagellates (at least to the Silurian) is formed from a more robust type of cell, the non-motile resting cyst, known to be produced by some living species. Most known cysts are organic-walled (called "acid resistant" cysts by 
palynologists) and are thought to fossilize due to sporopollenin-like material in the cyst wall (Brooks and Shaw, 1973). However, both living and fossil calcareous cysts are known (Deflandre, 1947, 1948; Wall and Dale, 1968b; Wall et al., 1970), and one group of siliceous cysts is documented from the Eocene (Dale, 1978).

The biological and paleontological significance of these two different stages in dinoflagellate life cycles (i.e., motile stages and cysts) was reviewed by Dale (1983). The biological literature provides little of direct relevance to paleontology, restricted as it is almost entirely to the motile stages commonly found in plankton. The cysts, which are morphologically very different from motile stages, seldom have been recorded in biological studies of plankton. They remained largely unknown until their discovery by paleontologists looking for living counterparts of fossil dinoflagellates (Evitt and Davidson, 1964; Wall, 1965).

Within the past 15 years several paleontologists have studied living and Recent dinoflagellate cysts for comparison with the fossil record. Their main objectives have been: 1) to investigate general factors producing cyst assemblages - particularly interesting since fossil cysts have been found to have increasing application in stratigraphic palynology, e.g., in oil exploration; and 2) to develop cysts as ecological indicators, particularly in Quaternary marine sediments. Two main approaches have been employed in these studies, one directed solely at Recent cysts, the other including living cysts.

Most dinoflagellate palynologists engaged in Recent studies have used standard preparation techniques (involving digestion of minerals by $\mathrm{HCl}$ and $\mathrm{HF}$ ) to extract acid resistant cyst assemblages from Recent bottom sediments. The main advantage of this approach is that it produces assemblages directly comparable with fossil assemblages similarly prepared. The main limitations are that mineralized cysts are destroyed and living cysts cannot be differentiated from dead cysts in the assemblages. In some cases this is an acceptable compromise that has proved particularly useful in documenting Recent cyst distribution (e.g., Rossignol, 1964; Williams, 1971; Reid, 1975; Dale, 1976; Wall et al., 1977).

Wall and Dale (1968a) developed techniques for studying living cysts including mineralized forms. In a series of investigations at the Woods Hole Oceanographic Institution from 1965 to 1975, these authors showed that cysts routinely form in the life cycles of many neritic dinoflagellates, apparently serving as benthic resting stages. At least in temperate waters, cyst formation was often markedly seasonal, and the cysts provided an obvious overwintering function. However, cysts also formed in tropical waters (Wall and Dale, 1970), and Dale (1976) suggested their overall function was probably as hypnozygotes in a sexual cycle.

In a first major ecological classification of living cysts, Wall et al. (1977) subsequently identified several oceanic types (members of the cyst based genus Leptodinium Klement, 1960, since transferred to Impagidinium Stover and Evitt, 1978). These are acid resistant cysts with a known fossil record extending back at least to the Middle Paleogene. That they are produced today in the open ocean was first suspected from palynological preparations of bottom sediments recovered by grabs and cores. Impagidinium species were consistently present in outer shelf and open ocean samples while virtually absent from inner shelf and coastal samples. Attempts to recover these live proved extremely difficult, but eventually several with fresh-looking cell contents were obtained from extensive plankton tows in slope waters off the U.S. East Coast, and from surface sediments carefully collected by me from the DSRV ALVIN at water depths of 1,000-2,000 m beneath the U.S. East Coast slope 
waters. Attempts to culture these in parallel experiments to those successfully used for coastal types (Wall and Dale, 1968a) all failed.

The discovery of open ocean dinoflagellate cysts raised many intriguing questions. Biologically, there are important questions concerning the function and strategy of cysts in the life cycles of oceanic dinoflagellates (discussed later). Geologically, the main questions concern which types of cysts are produced, in what amounts, their degree of preservability, and their ultimate contribution to the sediment flux. Results are presented here of an investigation aimed at answering these questions based on qualitative and quantitative microscopic examination of sediments collected by the PARFLUX project. These samples from large sediment traps placed at different depths in the deep sea provided a unique opportunity to supplement previous non-quantitative information from the two extremes of near surface plankton tows and bottom sediments. For the first time, an attempt was made to document living cysts sedimenting out through the deep sea water column today for comparison with cyst assemblages previously described from Recent deep sea sediments.

The overall aim was to provide paleontologically relevant information. Therefore, since only the cysts of dinoflagellates fossilize, the biocoenosis reported here is a biocoenosis of dinoflagellate cysts rather than their motile stages. Remains of motile stages were recorded when seen, but only limited attempts were made to identify these since they were often poorly preserved and considered outside the main scope of this work. Thoracosphaerids are described in Chapter 2 in this volume, since they are not considered to be closely related to dinoflagellate cysts reported here.

\section{Materials and Methods}

\section{Samples}

Figure 1.1 shows the location of sediment trap stations, and Table 1.1 summarizes the station data for samples used in this study. Details of the PARFLUX sediment traps, their deployments, and the collection and subdivision of samples obtained from them is presented elsewhere (Honjo et al., 1980; Honjo, 1980). Samples from all depths of Station PB, and Station E, $389 \mathrm{~m}$, represented $1 / 64$ of the original trap sample; others were $1 / 32$. A total of 15 trap samples and one bottom sediment sample were examined for dinoflagellates.

\section{Sample Preparation and Examination}

The work was carried out in two phases. The first batch of samples (from the Atlantic stations $S$ and E) were examined in 1979 as a pilot project to assess the value of this type of sample for dinoflagellate studies. Results from this were encouraging, and in 1981 the study was extended to include samples from the Pacific stations $P_{1}$ and PB.

The samples posed several problems not usually encountered together in dinoflagellate studies. These included:

1. The bulk of cysts proved to be calcareous, precluding the use of standard palynological preparation methods involving $\mathrm{HCl}$ and $\mathrm{HF}$. 


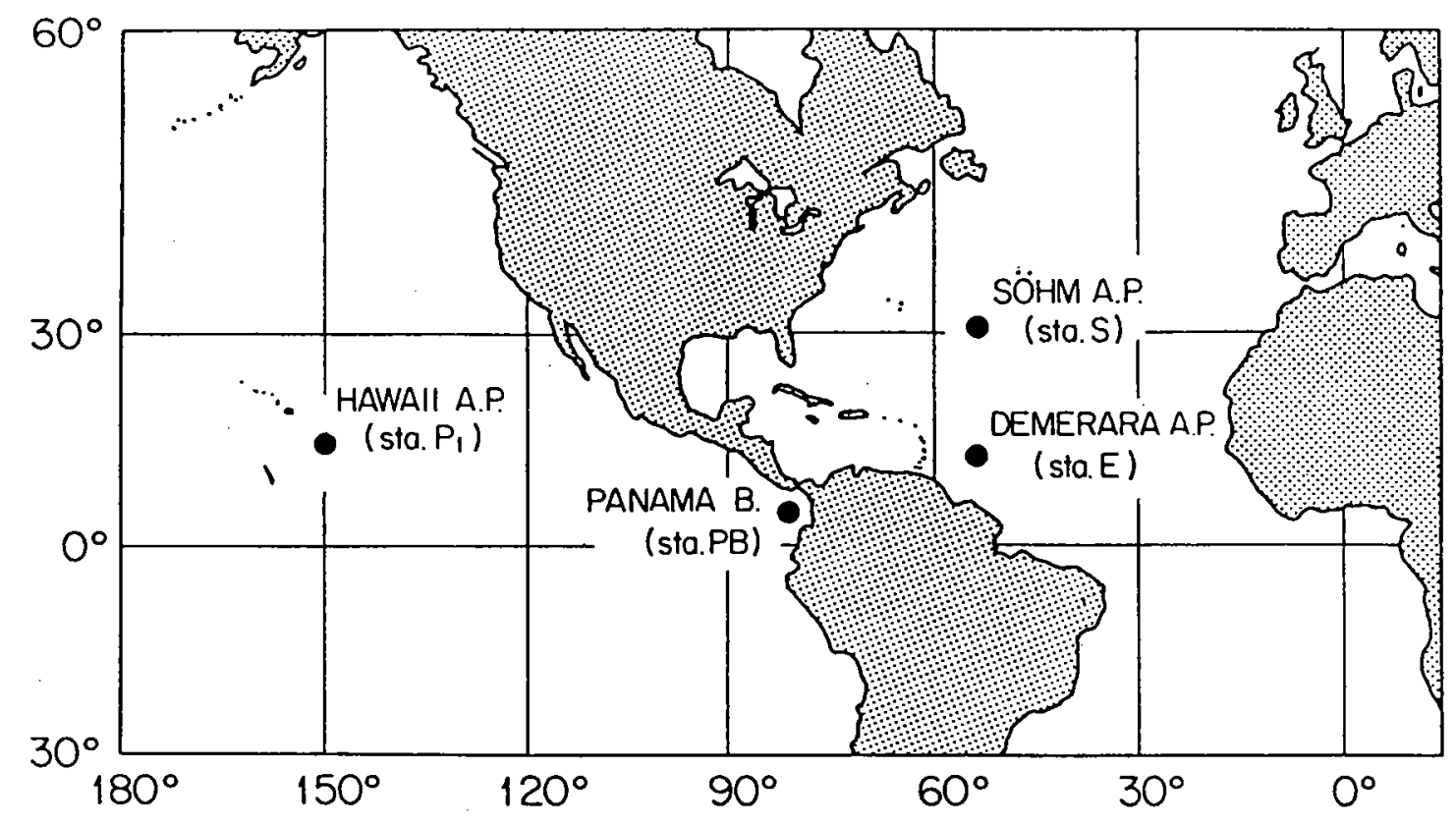

Figure 1.1: Location of PARFLUX sediment trap stations.

Table 1.1: Summary of station data and samples used for deep sea dinoflagellate studies.

\begin{tabular}{|c|c|c|c|c|}
\hline Station & PARFLUX $S_{1,2}$ & PARFLUX E & PARFLUX $P_{1}$ & PARFLUX PB \\
\hline Location & $\begin{array}{l}31^{\circ} 32.5^{\prime} \mathrm{N} \\
55^{\circ} 55.4^{\prime} \mathrm{W}\end{array}$ & $\begin{array}{l}13^{\circ} 30.2^{\prime} \mathrm{N} \\
54^{\circ} 00.1^{\prime} \mathrm{W}\end{array}$ & $\begin{array}{l}15^{\circ} 21.1^{\prime} \mathrm{N} \\
151^{\circ} 28.5^{\prime} \mathrm{W}\end{array}$ & $\begin{array}{l}05^{\circ} 21^{\prime} \mathrm{N} \\
81^{\circ} 53^{\prime} \mathrm{W}\end{array}$ \\
\hline Ocean/Basin & $\begin{array}{c}\text { Central } \\
\text { Sargasso Sea/ } \\
\text { Söhm } \\
\text { Abyssal Plain }\end{array}$ & $\begin{array}{c}\text { Tropical } \\
\text { Atlantic/ } \\
\text { Demerara } \\
\text { Abyssal Plain }\end{array}$ & $\begin{array}{c}\text { N. Central } \\
\text { Pacific/ } \\
\text { E. Hawaii } \\
\text { Abyssal Plain }\end{array}$ & $\begin{array}{c}\text { Tropical } \\
\text { Pacific/ } \\
\text { hemipelagic } \\
\text { Panama Basin }\end{array}$ \\
\hline Term & $10 / 76-1 / 77$ & $11 / 77-2 / 78$ & $7 / 78-11 / 78$ & $8 / 79-12 / 79$ \\
\hline Duration & 75 days & 110 days & 98 days & 112 days \\
\hline $\begin{array}{l}\text { Trap Depth } \\
\text { (m) }\end{array}$ & $\begin{array}{l}(372) \\
(976)^{a} \\
3,694^{a} \\
5,206 \\
5,367^{a}\end{array}$ & $\begin{array}{r}389^{a} \\
988^{a} \\
3,755^{a} \\
5,068^{a} \\
-\end{array}$ & $\begin{array}{c}378 \\
978 \\
2,778^{a} \\
4,280^{a} \\
5,582^{a}\end{array}$ & $\begin{array}{c}667^{a} \\
1,268 \\
(2,265) \\
2,869^{a} \\
3,769^{a}\end{array}$ \\
\hline $\begin{array}{c}\text { Ocean Depth } \\
\text { Sediment }\end{array}$ & $\begin{array}{c}5,581 \mathrm{~m} \\
\text { Box core }\end{array}$ & $5,288 \mathrm{~m}$ & $5,792 \mathrm{~m}$ & $3,856 \mathrm{~m}$ \\
\hline
\end{tabular}

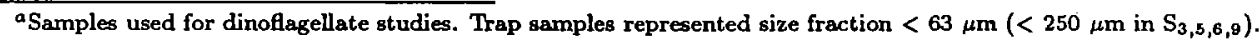


2. Diagnostic morphologic features of some of these calcareous cysts (e.g., crystalline structure of the wall) could not be resolved by light microscopy, necessitating the use of scanning electron microscopy (SEM).

3. Valid quantitative counts for cysts could not be made from SEM preparations, due to the "diluting" effect of large amounts of other material in the samples.

The following procedure was followed to obtain both qualitative and quantitative information from the trap samples:

1. After thoroughly shaking to homogenize the sample, an aliquot portion was wet sieved with a mesh size of $25 \mu \mathrm{m}$ routinely used for concentrating cysts.

2. The size fraction greater than $25 \mu \mathrm{m}$ retained on the sieve was counted for particles of identifiable dinoflagellate origin (see the next section for details), using normal light microscopy. In phase 1 of the project, counting was done from open drops on microscope slides (allowing manipulation of specimens), but in phase 2 permanent mounts in glycerine jelly ringed with beeswax were used. Counts were related back to the original sample, and results were expressed (as in Honjo, 1980) as a daily flux in a square meter section of water column at a given trap (Tables 1.2 and 1.3). This was calculated by dividing the total flux by the number of days the trap was deployed and the $1.5 \mathrm{~m}^{2}$ area of the trap opening.

3. The size fraction less than $25 \mu \mathrm{m}$ was spot-checked microscopically to see if significant dinoflagellate remains were being lost from the counts, and then permanently mounted in reference slides.

4. Sample material not used for the quantitative count was used for detailed morphologic studies of the various types encountered. For this, individuals were picked off with a micropipette, coated with gold using standard SEM preparation methods, and examined and photographed in the SEM. Permanent reference slides were made of any $>25 \mu \mathrm{m}$ fraction remaining after these studies.

5. The bottom sediment sample from Station $\mathrm{S}$ was sieved as in point 1 , above, and the fraction $>25 \mu \mathrm{m}$ was counted to obtain percentages of the various cysts making up the assemblage.

\section{The Organisms Recorded}

Organisms identified in this study as obviously of dinoflagellate affinity are discussed below under three categories: Thecae of dinoflagellate motile stages, organic-walled dinoflagellate cysts, and calcareous dinoflagellate cysts. Not so obviously of dinoflagellate affinity are calcareous organisms referable to the subfamily Thoracosphaeroideae Kamptner, 1928. Biological studies suggest that thoracosphaerids are in fact stages in the life cycle of a type of dinoflagellate (Tangen et al., 1982). However, these differ significantly from dinoflagellates described here (Tangen et al., 1982, created a new order, Thoracosphaerales, for these), and they are described in Chapter 2 in this volume. 
Table 1.2: Fluxes of dinoflagellate thecae.

\begin{tabular}{|c|c|c|c|c|c|c|c|c|c|c|c|c|}
\hline \multirow{2}{*}{$\begin{array}{c}\text { Station: } \\
\text { and } \\
\text { Depth (m) }\end{array}$} & \multicolumn{11}{|c|}{$\begin{array}{c}\text { Dinoflagellate Thecae } \\
\text { (type numbers) }\end{array}$} & \multirow{2}{*}{$\begin{array}{c}\text { Total } \\
\text { Flux } \\
\left(\mathbf{m}^{2} / \text { day }\right)\end{array}$} \\
\hline & 1 & 2 & 3 & 4 & 5 & 6 & 7 & 8 & 9 & 10 & 11 & \\
\hline S: 976 & 284 & 57 & 57 & 28 & & & & & 28 & & 57 & 426 \\
\hline 3,694 & 85 & & & & & & & & & & & 9.6 \\
\hline 5,369 & & & & & & & & & & & & - \\
\hline E: 389 & 50 & 14 & 8 & 70 & 12 & 10 & 31 & 4 & 17 & & 43 & 259 \\
\hline 988 & 39 & 19 & & & & & 10 & & 10 & 10 & 15 & 137 \\
\hline 3,755 & 39 & 10 & & & & & & & & 10 & & 59 \\
\hline 5,068 & 97 & & & & & & & & & & & 97 \\
\hline$P_{1}: 2,778$ & 22 & & & & & & & & & & & 22 \\
\hline 4,280 & 9 & & & & & & & & & & & 9 \\
\hline 5,582 & 22 & & & & & & 4 & & & & 4 & 30 \\
\hline $\mathrm{PB}_{1}: 667$ & & & 61 & & & & & & & & & 61 \\
\hline 1,268 & & & & & & & & & & & & 一 \\
\hline 2,869 & & 15 & & & & & & & & & & 15 \\
\hline 3,769 & & & 15 & & & & & & & & & 15 \\
\hline 3,791 & & & & & & & & & 25 & & 25 & 50 \\
\hline
\end{tabular}

\begin{tabular}{lll} 
Type 1 & $=$ Cladopyxis \\
Type 2 & $=$ Dinophysis \\
Type 3 & Heteraulacus \\
Type 4 & $=$ Pyrophacus \\
Type 5 & $=$ Protoceratium \\
Type 6 & $=$ Ornithocercus \\
Type 7 & $=$ Blepharocystis \\
Type 8 & $=$ Protoperidinium \\
Type 9 & $=$ Scrippsiella and Ensiculifera \\
Type 10 & Gonyaulax \\
Type 11 & $=$ Unidentified thecae \\
\hline
\end{tabular}


Table 1.3: Fluxes of dinoflagellate cysts.

\begin{tabular}{|c|c|c|c|c|c|c|c|c|}
\hline \multirow{2}{*}{$\begin{array}{c}\text { Station: } \\
\text { and } \\
\text { Depth (m) }\end{array}$} & \multicolumn{7}{|c|}{ Dinoflagellate Cysts } & \multirow{2}{*}{$\begin{array}{c}\text { Total } \\
\text { Flux } \\
\left(\mathbf{m}^{2} / \text { day }\right)\end{array}$} \\
\hline & $1^{a}$ & $\mathbf{2}^{b}$ & $\mathbf{3}^{c}$ & $4^{d}$ & $\mathbf{5}^{e}$ & $6^{f}$ & $7^{g}$ & \\
\hline S: 976 & 5,803 & 57 & 28 & & 114 & & & 6,002 \\
\hline 3,694 & 8,448 & & 85 & & 171 & & & 8,704 \\
\hline 5,369 & 2,304 & & 38 & & 171 & 57 & & 2,560 \\
\hline E: 389 & 5,353 & 128 & 19 & 2 & & 35 & 14 & 5,551 \\
\hline 988 & 5,595 & 112 & 29 & 10 & 63 & 24 & 48 & 5,857 \\
\hline 3,755 & 12,422 & 184 & 136 & & 78 & 349 & 48 & 13,217 \\
\hline 5,068 & 13,750 & 136 & 58 & & 78 & 524 & 38 & 14,584 \\
\hline$P_{1}: 2,778$ & 1,833 & 9 & & & 30 & 96 & & 1,968 \\
\hline 4,280 & 1,467 & 9 & & & 4 & 87 & & 1,567 \\
\hline 5,582 & 392 & & & & 9 & & & 401 \\
\hline $\mathrm{PB}_{1}: 667$ & 2,368 & 30 & & & & & 30 & 2,422 \\
\hline 1,268 & 2,347 & 76 & & & & 15 & 152 & 2,590 \\
\hline 2,869 & 2,347 & 137 & & & 107 & & 335 & 2,926 \\
\hline 3,769 & 3,474 & 122 & 15 & & & 15 & 290 & 3,916 \\
\hline 3,791 & 2,184 & 51 & 102 & & & & 330 & 2,667 \\
\hline
\end{tabular}

${ }^{a} \mathrm{cf}$. Thoracosphaera albatrosiana (see text for forms included)

${ }^{6}$ Calciodinellum operosum

'Scrippsiella cf. S. trochoidea

${ }^{d}$ Bicarinate-type

e?Calcareous cyst sp.

${ }^{f}$ Unidentified calcareous cysts

${ }^{9}$ Undifferentiated spherical brown protoperidinioid cysts 


\section{Dinoflagellate Thecae}

Remains of motile dinoflagellates were of only passing interest in this study (as explained earlier). No unarmored dinoflagellates were observed, only the thecae (usually empty) of armored forms. Many were broken and partially decayed, but where possible these were identified at least to genus level. Most of these were robust types commonly recorded from open ocean plankton studies (e.g., Blepharocystis, Ornithocercus, Cladopyxis, Dinophysis, Heteraulacus, and Protoperidinium, illustrated in Plate 1.1, figures 1-6). However, small, seemingly fragile thecae were sometimes seen, and occasionally identified as species of either Scrippsiella (Plate 1.1, figure 9) with a distinctive plate pattern including 6 cingular plates or Ensiculifera with a prominent lance-like first cingular plate (Plate 1.1, figure 10).

It should be noted that Cladopyxis (Plate 1.1, figures 11-12) is included with the thecae since other workers have reported thecal plates in species of Cladopyxis (Taylor, 1976). However, no thecal plates were seen in the examples studied here, and the possibility that at least some of the specimens recorded here may be hitherto undescribed cysts is discussed later.

\section{Organic-walled Cysts}

Protoperidinium: Only a few types of organic-walled cysts were seen in sediment trap samples. Almost all of those encountered were spherical brown cysts of the type produced by many species of Protoperidinium. This group of cysts is one of the most difficult to identify at species level. Their simple body shape is indistinctive, and species are usually differentiated only by the diagnostic shape of the excystment aperture (the archeopyle). Often this feature is difficult to resolve in all but freshly excysted specimens, since either the cyst died before the archeopyle opened or the archeopyle shape becomes obscured by folding of the empty cyst wall. The sizes of specimens seen in the present study suggested the possibility of at least three distinct types with body diameters around $26 \mu \mathrm{m}, 36 \mu \mathrm{m}$ and $50 \mu \mathrm{m}$, respectively. However, archeopyle shape could not be resolved in most cases and as in many other reports they were simply recorded as undifferentiated spherical Protoperidinium cysts. One distinctive type was recognized, Protoperidinium sp. (Plate 1.1, figure 18), closely resembling $P$. avellana (Wall and Dale, 1968a) but smaller (26-30 $\mu \mathrm{m}$ diameter).

Impagidinium sphaericum (Wall) Harland, 1983 (Plate 1.1, figure 20) = Leptodinium sphaericum Wall, 1967, p. 108-109, Pl. 15, figs. 11, 12: This species shows diagnostic features of paraplates 1' and 4' used by Stover and Evitt (1978) to define the genus Impagidinium.

Dinoflagellate cyst; Form B Wall et al., 1977, Pl. 1, fig. 2: A small cyst (cyst body around $36 \mu \mathrm{m}$ diameter) with $8-10 \mu \mathrm{m}$ long processes which are blade-like with clavate tips. First recorded from Recent shelf sediments near Pisco, Peru.

Other Organic-walled Cysts: Apart from the above types found in sediment trap samples, an assemblage composed entirely of organic-walled cysts was recovered from the bottom sediment at Station S. Percentages of the various cyst types counted are shown 
Table 1.4: Dinoflagellate cyst assemblage in bottom sediment from Station S.

\begin{tabular}{|lc|}
\hline \multicolumn{1}{|c|}{ Dinoflagellate Cysts } & $\begin{array}{c}\text { Percentage } \\
\text { Abundance }\end{array}$ \\
\hline Operculodinium centrocarpum (Defiandre \& Cookson) Wall, 1967 & 31 \\
Spiniferites bulloideus (Deflandre \& Cookson) sensu Wall, 1965 & 2 \\
S. membranaceus (Rossignol) Sarjeant, 1970 & $<1$ \\
S. elongalus Reid, 1974 & 5 \\
S. spp. (unidentified) & 1 \\
Bitectatodinium tepikiense Wilson, 1973 & 8 \\
Planinosphaeridium choanum (Reid) Wall et al, 1977 & 1 \\
Lingulodinium machaerophorum (Deflandre \& Cookson) Wall, 1967 & $<1$ \\
Protoperidinium conicoides (Paulsen) Balech, 1974 & 2 \\
Undifferentiated spherical, brown protoperidinioid cysts) & 31 \\
Peridinium faeroense (Paulsen) Dale, 1977 & 18 \\
\hline \hline
\end{tabular}

in Table 1.4; additional rare specimens of Impagidinium patulum (Wall) Evitt and Stover, 1978, were seen in reference slides.

\section{Calcareous Cysts}

It is not always easy to identify a dinoflagellate cyst as such unless the direct link between cyst and motile stage has been established either by observing cyst formation in the motile stage or excystment producing a motile stage. Obviously, this will never be possible for most fossil cyst types, and these are defined morphologically. Occasionally, overall body shape is distinctive enough (e.g., allowing recognition of fossil cysts of Ceratium or Gymnodinium affinities), but the main criteria used are evidence of paratabulation (see Evitt et al., 1977, for definition) or an archeopyle. In practice, the archeopyle usually must show thecal-platelike affinities for it to be used alone to define a dinoflagellate cyst as such.

Such morphologic definition has obvious weaknesses. For example, Lister (1970) pointed out its bias towards cysts of thecate dinoflagellates, since the cysts of forms lacking thecal plates in the motile stage may be expected to similarly lack paratabulation and distinctive archeopyles. But despite such limitations, the established morphologic definition remains the most practical approach to unknown forms. This is no less so for calcareous cysts encountered in the present study, and those recognized based on morphologic criteria are discussed below.

Calciodinellum operosum Deflandre, 1947 (Plate 1.1, figure 13; Plate 1.2, figures 1-20): This was the most easily identified calcareous cyst seen in the present study. Details of 
paratabulation and archeopyle from light microscope observations agreed with those of Deflandre $(1947,1948)$ and Wall and Dale (1968b), while skeletal details (including the range of variability) seen in SEM agreed with the description of Fütterer (1977). The observations by Fütterer (1977, pl. 6, fig. 12) of an additional paraplate sometimes seen between paraplates 2', 4' and 3' on the operculum is confirmed here (Plate 1.2, figure 13). This is almost certainly equivalent to the apical pore characteristic for thecae of species belonging to the genera known to produce calcareous cysts, Scrippsiella and Ensiculifera (e.g., Plate 1.1, figure 9).

cf. Thoracosphaera albatrosiana Kamptner, 1963 (Plate 1.1, figures 14-15): Many cysts were seen in this study whose general morphologies agree with that of $T$. albatrosiana. Their overall appearance in light microscopy is shown in Plate 1.1, figures 14-15. Their size and archeopyle type are very similar to those of Calciodinellum operosum, but parasutural ridges are not developed. Details of ultrastructure from SEM observations suggest that several different types (not distinguishable in light microscopy) were probably included under this "taxon" in quantitative counts using the light microscope. These almost certainly included T. albatrosiana sensu Fütterer (1977) (Plate 1.3, figure 12) and the "granular form" of T. albatrosiana of Fütterer (1977) (Plate 1.1, figures 9-11). They may also have included T. albatrosiana Kamptner, 1963, sensu Fütterer (1977) (Plate 1.3, figures 1-8).

These obvious dinoflagellate cysts with distinctive archeopyles are not considered to be cogeneric with Thoracosphaeroideae. They should ultimately be removed from Thoracosphaeroideae, but formal transfer is not proposed here pending the results of culture work on this group.

Scrippsiella cf. Scrippsiella trochoidea (Stein) A.R. Loeblich III (Plate 1.4, figures 111): Spinose calcareous cysts generally resembling those described from Peridinium trochoideum by Wall and Dale (1968b) and Wall et al. (1970). Details of the forms encountered here seen in SEM were very similar to those described by Fütterer (1977) as Peridinium cf. Peridinium trochoideum (Stein) Lemmermann.

Bicarinate-type Wall and Dale, 1968b, p. 1405; text-fig. 3, 4-6; Pl. 172, figs. 14-15: A few specimens of this distinctive form were seen at one station. Size (40-50 $\mu \mathrm{m})$ and characteristic parasutural ridge patterns agreed with the descriptions of Wall and Dale (1968b). Previously recorded from bottom sediments at Bermuda and various parts of the Caribbean region.

?Calcareous cyst sp. (Plate 1.3, figure 20; Plate 1.4, figures 12-13): A few distinctly elongate to oval calcareous tests were seen, around $25 \mu \mathrm{m}$ in maximum width, with a skeletal ultrastructure resembling those of other dinoflagellate cysts recorded (Plate 1.4, figure 13). Though no definitive archeopyle was noted, Plate 1.3, figure 20 suggests a possible apical archeopyle. 


\section{Results and Discussion}

In discussing results from the present investigation, it should be stressed from the outset that this was the first time that trap samples of this type were studied for dinoflagellates. Prior to this, information concerning open ocean dinoflagellate cysts was restricted either to occasional records from near surface plankton studies (e.g., Gaader, 1954; Wall et al., 1977; Reid, 1978) or from bottom sediments (see refs. in Harland, 1983). Therefore, a major objective of this work was to provide information, if possible, linking these otherwise extreme views of the deep sea. The results obtained are discussed here specifically as they relate to the types of dinoflagellates produced, the amounts produced, their preservability and ultimate contribution to the sediment flux.

\section{Dinoflagellate Thecae}

Observations of dinoflagellate thecae are summarized in Table 1.2. Most of those identified were robust types commonly reported from living plankton within the photic zone. Of particular interest here are several types which probably form cysts.

Specific thecal types corresponding to most of the cysts recorded here are not known, since the oceanic cysts have never been successfully incubated, but comparisons can be made with cyst/theca correlations from coastal waters. For example, these suggest that calcareous cysts are produced by a closely related group of small orthoperidinioid dinoflagellates including the genera Scrippsiella and Ensiculifera (Wall and Dale, 1968a, 1968b; Wall et al., 1970; Dale, 1977). Thecae of this type (Type 9, Table 1.2) recorded here from three of the four stations probably represent the dinoflagellate motile stages producing the calcareous cysts recorded. Particularly noteworthy is the presence at Station E both of thecae of this type and calcareous cyst Type 4 (Table 1.3). These cysts are common in bottom sediments from the nearest shallower water regions of the Caribbean, and examples from Bermuda were incubated to produce thecae similar to those of Type 9 in Table 1.2 (Wall and Dale, 1968b). Thecae belonging to Ensiculifera seen in the upper two samples from Station E are believed to represent the first records of this genus from open oceanic waters. Other thecae possibly representing cyst-forming species were those of Protoperidinium (many species of which produce spherical brown cysts of the type numbered 7 in Table 1.3) and Gonyaulax. Particularly one theca seen from $3,755 \mathrm{~m}$ at Station E, a member of the Gonyaulax spinifera group with a markedly displaced girdle and one antapical spine, represented a type which might be expected to produce cysts belonging to the cyst genus Impagidinium (based on morphological similarities).

Comparatively few thecae were seen in the trap samples (e.g., compared with the number of cysts). Their recorded occurrences were mostly sporadic with no obvious patterns of distribution. However, absolute amounts and species diversity generally decreased with increasing water depth, and very few were seen below $1,000 \mathrm{~m}$. These general trends were best seen at Station $E$ which also included significant numbers of thecae containing the remains of cell contents. Percentages of thecae containing cell contents were: Type 1: 48 percent at $389 \mathrm{~m}, 28$ percent at $988 \mathrm{~m}$, and none at greater depths; Type 7: 100 percent at the upper two depths and none below; Type 8: 50 percent at $389 \mathrm{~m}$ and none below. The general trends noted above are not surprising since thecae are supposedly composed of cellulosic material and are generally presumed to decay soon after death. But the presence of even 
a few thecae at water depths so far below the photic zone was unexpected. These may have been transported fairly rapidly by zooplankton fecal pellets as described for other phytoplankton remains by Honjo (1976).

One type of "theca" recorded here, Cladopyxis (Type 1, Table 1.2), showed a markedly different distribution. Though not present in the Panama Basin samples (PB), this was the most abundant type consistently found at all depths studied from the other three stations. Its distribution is notably similar to the cyst distribution shown in Table 1.3, including an increase at 5,068 $\mathrm{m}$ at Station E. Morphologically, Cladopyxis (Plate 1.3, figures 11-12) with substantial branched processes and a prominent "opening" in the empty test basically resembles a cyst. However, flagella and thecal plates previously recorded in similar cells from near surface phytoplankton samples clearly establish these as motile dinoflagellates (Taylor, 1976). Flagella would not be expected in the dead cells recorded from trap samples here, but thecal plates should be preserved. So far, a close examination (including SEM) of a few examples has not revealed thecal plates (e.g., Plate 1.4, figures 14-16). Therefore, based on present information it seems possible that at least some of the Cladopyxis reported here may represent cysts persisting at great depths due to a more resistant cyst wall. Ironically, such cysts would probably go undetected in phytoplankton studies since Cladopyxis is established in the literature as a "cyst-like" motile stage.

No thecal remains were seen in bottom sediment from Station $S$, and they have never been reported elsewhere from deep sea sediments. The present study suggests that most of the thecae, which may be relatively abundant in the photic zone, probably break down within the upper few hundred meters of the ocean. A few may be transported to greater depths, but these too are presumed to break down before incorporation into bottom sediments is possible.

\section{Dinoflagellate Cysts}

The most striking feature of dinoflagellate cysts recorded here (Table 1.3) was the overwhelming dominance of calcareous cysts. Prior to this work the little available evidence suggested that calcareous cysts are relatively unimportant in temperate neritic assemblages, while becoming more important in tropical assemblages. For example, Dale $(1976$, p. 43) reported only 1-2 percent in Norwegian fjord assemblages, whereas Wall and Dale (1968b) found abundant calcareous cysts in tropical neritic sediments, though never dominating the assemblage to the extent seen here. By far the most common type of calcareous cyst recorded here (Type 1, Table 1.3) is known so far only from the deep sea (e.g., the fossils recorded by Fütterer, 1977). Its abundance here suggests that these cysts are routinely produced by oceanic dinoflagellates, probably small orthoperidiniums belonging to the genera Scrippsiella or Ensiculifera (Type 9, Table 1.2). The second most abundant calcareous cyst, Calciodinellum (Type 2, Table 1.3) is previously recorded from deep sea sediments (e.g., Fütterer, 1977) and slope water plankton and a cyst with cell contents was seen by the author in a slope water plankton sample taken September 21, 1971, off the East Coast, U.S.A. $\left(39^{\circ} 56^{\prime} \mathrm{N}, 70^{\circ} 59^{\prime} \mathrm{W}\right)$. Cysts similar to other types seen here (e.g., Types 3 and 4 , Table 1.3) are known also from coastal waters.

Very few organic-walled cysts were seen in sediment trap samples. Only one example was seen of cysts belonging to the oceanic cyst genus Impagidinium, a single specimen of $I$. 
sphaericum seen in a non-quantitative reference slide from Station $\mathrm{P}_{1}, 2,778 \mathrm{~m}$. This was surprising, since cysts belonging to Impagidinium are elsewhere commonly recorded from deep sea sediments and occasionally from slope water plankton (e.g., Wall et al., 1977). Organic-walled cysts were represented almost entirely by largely unidentifiable spherical brown protoperidinioid cysts (Type 7, Table 1.3), a type of cyst not usually dominant in deep sea assemblages of organic-walled cysts. The only other organic-walled cysts seen were several specimens of cyst Form B (Wall et al., 1977) seen in reference slides of Station PB, $3,791 \mathrm{~m}$.

Estimates of the contribution of dinoflagellate cysts to the sediment flux are shown in Table 1.3. This suggests a general contribution of at least several thousands of small calcareous bodies $(25-30 \mu \mathrm{m}$ diameter $) / \mathrm{m}^{2} /$ day, together with insignificant numbers of organic-walled forms. Since the bulk of these are calcareous, their ultimate fate in the sedimentary regime is probably similar to that of foraminifers and coccoliths. Some of them are almost certainly transported fairly rapidly through the water column to great depths in fecal pellets as described for other organisms by Honjo (1976). If not dissolved, these may accumulate in sediments at least in paleontologically significant amounts (shown by a fossil record in deep sea sediments from Paleogene to Present time). However, large scale dissolution of these and other calcareous particles was probably illustrated here at Station S, where the largely calcareous cyst assemblage seen in trap samples (Table 1.3) could not be compared with the bottom sediment assemblage containing only organic-walled cysts (Table 1.4).

\section{Comparisons between Stations}

Comparing the dinoflagellate flux observed here with available data from other studies of the same trap samples suggests that despite obvious limitations the dinoflagellate record reflects some of the main features of production and sedimentation in the deep sea. Most thecal remains are relatively short-lived and therefore offer no viable basis for comparison, but the distribution of dinoflagellate cysts at the various stations may be compared. Total flux of cysts suggests that the stations may be ranked as follows according to their reflected productivity (from highest to lowest): stations E, S, PB, and P. This agrees with other observations (e.g., total sediment flux estimated by Honjo, 1980).

The dinoflagellate cyst data suggest several main trends, the significance of which is not yet apparent. These include a trend towards increased amounts of cysts at depths between 3,000-4,000 $\mathrm{m}$ (stations S, E, and PB), and a trend towards reduced amounts of cysts at lower depths (stations S, P, and PB). The large increase in cysts in the lower two traps at Station E parallels increases in total sediment flux estimated by Honjo (1980). Organicwalled protoperidinioid cysts (Type 7, Table 1.3) were only recorded at stations $\mathrm{E}$ and $\mathrm{PB}$, where they tended to increase with depth. These cysts may in some way reflect the fact that stations $\mathrm{E}$ and $\mathrm{PB}$ were significantly nearer to continental land masses.

\section{Biological Discussion}

The cyst data here support earlier observations by Wall et al. (1977) that cyst formation is not restricted to neritic dinoflagellates but includes some oceanic types. This raises 
fundamental questions of how these oceanic cysts compare with previously described benthic resting cysts of neritic dinoflagellates, particularly concerning production and function in the life cycle.

\section{Comparison between Oceanic Cysts and Neritic Cysts}

The consistent abundance of cysts recorded here at all stations and most depths strongly suggests that they are routinely produced in the life cycles of the dinoflagellates concerned. However, only a few oceanic cyst types were seen, though a wide variety of dinoflagellates (probably several hundreds of species) have been reported elsewhere in plankton studies from these regions. Most of the observed oceanic cysts are probably produced by a very small portion of the more obscure dinoflagellates, species of Scrippsiella and Ensiculifera which seldom if ever appear in oceanic plankton records. Thus, it seems likely that a far smaller proportion of oceanic species are cyst-forming than, for example, the 20 percent recorded by Dale (1976) in north temperate plankton of a Norwegian fjord. This, together with the relative importance of calcareous forms, suggests that oceanic cyst formation is much more comparable with that of tropical neritic dinoflagellates, though at present this is poorly documented.

The oceanic cysts are morphologically similar to other dinoflagellate cysts. They are presumed here to serve the same basic function as hypnozygotes in a sexual cycle, though not as benthic resting stages. Alternative suggestions for their mode of functioning are: 1) their buoyancy may allow them to remain strategically placed in the water column; or 2) they may complete their sexual function at a rate allowing excystment before the cyst sinks to a depth from which the emerging motile stage can no longer reestablish contact with the plankton.

Like benthic resting cysts, oceanic cysts may be able to withstand adverse conditions for up to several years, facilitating dispersal and possibilities for transport to more favorable environments. Interestingly, almost none of the oceanic cysts showed functional morphology obviously hindering sinking (e.g., long spines, "wings", or other projections from the wall). On the contrary, by far the most common cysts have thick calcareous walls more suggestive of a sinking strategy. Possible advantages to such a strategy may include removing the cell from relatively higher levels of predation in the biologically more active photic zone, and gaining access to nutritionally richer waters usually found a little deeper in the water column.

\section{Paleontological Discussion}

This study represents an extension of previous studies of present day distributions of dinoflagellate cysts largely from neritic environments, particularly work by Dale (1976) and Wall et al. (1977). The ultimate aim is to assess how representative of plankton the cyst record seen by paleontologists is, and to develop the use of dinoflagellate cysts as paleoenvironmental indicators (particularly in the Quaternary) based on an understanding of their distribution today. Here, for the first time, cysts recovered from deep sea sediment traps provided information concerning oceanic cyst production and preservation. Having demonstrated the main types of cysts produced and deposited out from plankton, the next important step was to compare this cyst flux with the assemblages in bottom sediments 
recorded by paleontologists. Such a comparison should help to indicate the extent to which assemblages in bottom sediments reflect overlying water masses or, for example, lateral transport of cysts, a factor which may be expected to be more important in the deep sea, given the large vertical distance $(4-5 \mathrm{~km})$ between phytoplankton and bottom sediments.

\section{Comparison between Cysts from Sediment Traps and Cyst Assemblages from Deep-Sea Bottom Sediments}

As yet there have been few studies of cyst assemblages from Recent deep-sea sediments. Almost all are from the North Atlantic Ocean and adjacent seas and they are restricted to organic-walled cysts remaining after acid treatments. The most significant published reports are from Williams (1971), Wall et al. (1977), Turon (1980), and Harland (1983) containing a very useful summary of previous studies supplemented by his own data from 49 stations. Though Harland's work represents the most comprehensive data available for deep-sea cyst assemblages, the following factors combine to make it extremely difficult to compare these with sediment trap data presented here:

1. Calcareous cysts: These cysts, which totally dominate trap samples, would be destroyed by palynological methods used to extract the organic-walled cysts summarized by Harland (1983), precluding any comparison. The problem is not restricted to preparation methods, since calcareous cysts are probably destroyed naturally by dissolution in many deep-sea sediments. For example, this is presumed to be the case at Station $S$ where it proved virtually impossible to compare the cyst flux seen in trap samples (Table 1.3) with the cyst assemblage seen in bottom sediment (Table 1.4). Trap samples yielded a rich assemblage composed entirely of calcareous cysts, while bottom sediment contained a rich assemblage composed entirely of organic-walled cysts. Therefore, at least two very different types of deep-sea sediments may yield very different cyst assemblages. Calcareous rich sediments may be expected to contain cyst assemblages overwhelmingly dominated by calcareous forms comparable with the flux seen here, and therefore most representative of oceanic cyst production, while sediments depleted in calcium carbonate nevertheless may contain rich assemblages of organic-walled cysts (as seen at Station S).

2. The time scale involved and possible dissolution of organic-walled cysts: Sedimentation rates may be extremely low with bioturbation causing mixing in bottom sediments. For example, sedimentation rates of about $1 \mathrm{~cm}$ per thousand years are considered normal for the deep sea, and Kennett (1982) quotes intense bioturbation mixing down to at least $10 \mathrm{~cm}$, with documented examples of implied mixing of Indian Ocean sediments averaging 120,000 years. Thus, even "surface sediments" recovered by conventional grabs or cores may contain sediments which are many thousands of years old and therefore not necessarily comparable with the present day flux. This is particularly the case where dissolution of the carbonates further reduces the total sediment volume accumulating. In extreme deep sea sedimentary conditions where red clays are deposited, even the few very resistant organic-walled cysts are generally presumed to break down (oxidize) eventually in the relatively long time awaiting burial, though Williams (1971) reported some organic-walled cysts from red clays. 
Major discrepancies between the sediment trap results (giving little or no evidence of organic-walled cysts) and the seemingly rich assemblages of organic-walled cysts found in many sediments from the deep ocean floor cannot be explained with certainty at present. However, other studies (Dale, in progress), results of which will be presented elsewhere, suggest long distance transport of most organic-walled cysts.

\section{The Supply of Cysts to Deep-Sea Sediments}

Though not encountered in the present study, there is evidence elsewhere for calcareousrich deep sea sediments containing calcareous cysts comparable with fluxes described here. Fütterer (1977) described some from pelagic sediments of Oligocene to Pleistocene age at DSDP Leg 41, Site 66, on the Sierra Leone Rise in the eastern North Atlantic, and Gilbert and Clark (1983) from Late Cenozoic sediments from the Central Arctic Ocean. The present study suggests a steady supply of such cysts from the phytoplankton to bottom sediments, and both qualitatively and quantitatively they probably are representative for overlying waters. Calcareous cysts thus may well be useful stratigraphic and paleoecological indicators in deep sea sediments, but this potential has not yet been realized. Such cysts are not included in palynology since they are destroyed by preparation methods, and at 20-50 $\mu \mathrm{m}$ they are generally too small to be included in foraminiferal studies and too large for nannoplankton studies.

Dissolution almost certainly explains the absence in bottom sediments of calcareous cysts such as those seen in the sediment flux, but the opposite case (so prominently encountered here) of organic-walled cysts in bottom sediments but undetected in the sediment flux is not easily explained. The organic-walled cysts found in bottom sediment at Station S and other samples from the western North Atlantic (summarized by Harland, 1983) are of three main types, based on ecological classifications by Wall et al. (1977) and Dale (1983). A significant amount are previously considered to be cold temperate neritic cysts, a smaller amount are oceanic cysts, and the remainder are large numbers of the cosmopolitan cyst Operculodinium centrocarpum. Determining the sources of these cysts in bottom sediments is critical for eventually using such cysts as paleoenvironmental indicators in oceanic sediments.

Previous workers, including Harland (1983), have interpreted the distribution patterns of organic-walled cysts in deep sea bottom sediments as reflecting immediately overlying surficial water masses. The present study suggests an alternative hypothesis for their presence in deep sea sediments of the western North Atlantic. Cold temperate cysts and the cosmopolitan $O$. centrocarpum were not seen in sediment trap samples though they dominated bottom sediment assemblages, and they are considered to be most likely transported long distances by bottom water masses.

One element in assemblages of organic-walled cysts in deep sea sediments, represented by species of Impagidinium, almost certainly represents oceanic cyst production today. Sediment trap samples yielded fragmentary evidence for a few such cysts in the sediment flux, but this suggests that production may be relatively low. Ironically, these cysts, which alone may truly represent oceanic conditions, may account for only a minor percentage composition of the assemblage in bottom sediments if relatively large amounts of other cysts are transported in from regions of much higher cyst production, as postulated here. 


\section{Summary}

1. Thecal remains of dinoflagellate motile stages are almost entirely restricted to the upper few hundred meters of the deep sea water column, supporting the generallyaccepted explanation of their absence in the fossil record (i.e., thecae are composed of cellulosic material which is destroyed before they may be incorporated into bottom sediments).

2. Only the type of "theca" with general morphology identical to the genus Cladopyxis persisted to abyssal depths. However, unlike Cladopyxis motile stages previously described from plankton, forms examined here revealed no thecal plates and may represent undescribed cysts with more resistant walls.

3. Only a few oceanic cyst types were seen, though probably several hundreds of dinoflagellate species have been reported elsewhere in plankton studies from these regions. Therefore, probably a far smaller proportion of oceanic dinoflagellates are cyst-forming than, for example, the 20 percent recorded by Dale (1976) for north temperate plankton of a Norwegian fjord.

4. Oceanic cysts probably serve the same basic function as their coastal and neritic counterparts (i.e., hypnozygotes in a sexual cycle) though not as benthic resting stages. Alternative strategies may include completing their sexual function at a rate allowing excystment before the cyst naturally sinks too deep, or buoyancy to remain strategically placed in the water column allowing dipersal and possibilities for transport to more favorable environments.

5. In the deep sea, at least in tropical and subtropical regions, the cyst assemblage sedimenting out from plankton at present is overwhelmingly dominated by calcareous forms. Both the Atlantic Ocean and the Pacific Ocean are characterized by the same few species with relatively long geological histories, probably reflecting a relatively stable environment over a long time. They include several types at present classified as thoracosphaerids, but which are obviously dinoflagellate cysts and therefore should be transferred.

6. By far the most common cyst type recorded (cf. Thoracosphaera albatrosiana) is known so far only from the deep sea. Abundances of this and other calcareous cysts suggest these are routinely produced by a very small portion of the more obscure oceanic dinoflagellates, probably small orthoperidiniums belonging to the genera Scrippsiella or Ensiculfera, which seldom, if ever, appear in oceanic plankton records.

7. Very few organic-walled cysts were seen in trap samples, suggesting that production of cysts recoverable by palynological methods may be extremely low (e.g., only one specimen was seen belonging to the oceanic cyst-genus Impagidinium).

8. Dinoflagellates probably contribute at least several thousands of small calcareous cysts (mostly $25-30 \mu \mathrm{m}$ diameter) $/ \mathrm{m}^{2} /$ day to the sediment flux together with insignificant amounts of organic-walled forms. If not dissolved, these may accumulate in bottom sediments at least in paleontologically significant amounts (shown by a fossil record 
in deep sea sediments from Paleogene to Present). Total amounts present seem to reflect general phytoplankton productivity.

9. Large scale dissolution of cysts and other calcareous particles was probably illustrated here at Station S (Söhm abyssal plain) where the largely calcareous cyst assemblage seen in trap samples could not be compared with the bottom sediment assemblage containing only organic-walled cysts.

10. Where not dissolved, calcareous cysts probably offer the most representative stratigraphical and paleoecological record of oceanic dinoflagellates in deep sea sediments. To date, this potential has been generally overlooked by paleontologists since calcareous cysts are dissolved by palynological preparation methods and at $20-50 \mu \mathrm{m}$ they are too small to be included in foraminiferal studies and too large or dispersed for nannoplankton studies.

11. "Oceanic assemblages" of organic-walled cysts from Recent deep sea sediment previously described by palynologists (e.g., Harland, 1983) probably do not accurately reflect production in overlying surficial water masses. They may include older cysts reflecting oceanic conditions different from today, or, more likely, they may represent mainly long distant transport by bottom water masses.

12. If organic-walled cysts are transported extremely long distances, as postulated here, they may prove useful as tracers for bottom water masses and sources of silt to deep sea sediments.

\section{Acknowledgements}

I wish to thank Dr. Susumu Honjo for inviting my participation in the PARFLUX project and for his enthusiastic encouragement throughout the work reported here. Technical assistance of Dr. Kozo Takahashi with part of the SEM work, and of Robert Williams with photographic printing, is also gratefully acknowledged. The samples used in this research were collected during the 1976 to 1979 PARFLUX experiments and the 1979 Sediment Trap Intercomparison Experiment which were supported by NSF Grants: OCE-7682063, OCE-7727004, and OCE-7925429.

\section{References}

Brooks, J. and G. Shaw (1973). The role of sporopollenin in palynology. In: Problems of Palynology, M.I. Neustadt (ed.), Proceedings of 3rd International Palynology Conference, pp. 8-91.

Dale, B. (1976). Cyst formation, sedimentation, and preservation: factors affecting dinoflagellate assemblages in Recent sediments from Trondheimsfjord, Norway. Review of Palaeobotany and Palynology, 22:39-60. 
Dale, B. (1977). New observations on Peridinium faeorense Paulsen (1905) and classification of small orthoperidinioid dinoflagellates. British Phycological Journal, 12:241253.

Dale, B. (1978). Acritarchous cysts of Peridinium faeorense Paulsen: implications for dinoflagellate systematics. Palynology, 2:187-193.

Dale, B. (1983). Dinoflagellate resting cysts: "benthic plankton". In: Survival Strategies of the Algae, G.A. Fryxell (ed.), Cambridge University Press, New York, pp. 69-136.

Deflandre, G. (1947). Calciodinellum nov. gen., premier répresentant d'une famille nouvelle de Dinoflagellés fossiles a theque calcaire. Academie de science Comptes Rendus, 224:1781-1782.

Deflandre, G. (1948). Les Calciodinellidès-dinoflagellès fossiles a theque calcaire. Botanistre, 34:191-219.

Evitt, W.R. and S.E. Davidson (1964). Dinoflagellate studies. 1. Dinoflagellate cysts and thecae. Stanford University Publications, Geological Science, 19(1):1-12.

Evitt, W.R., J.K. Lentin, M.E. Millioud, L.E. Stover and G.L. Williams (1977). Dinoflagellate cyst terminology. Canadian Geological Survey, Paper 76-24, pp. 1-11.

Fütterer, D. (1977). Distribution of calcareous dinoflagellates in Cenozoic sediments of Site 366, Eastern North Atlantic. In: Y. Lancelot, E. Siebold, et al., Initial Reports of the Deep Sea Drilling Project, Vol. 41, U.S. Government Printing Office, Washington, D.C., pp. 709-737.

Gaarder, K.R. (1954). Coccolithineae, Silicoflagellattae, Pterospermataceae and other forms from the "Michael Sars" North Atlantic Deep-Sea Expedition 1910. Report on the Scientific Results of the "Michael Sars" North Atlantic Deep-Sea Expedition, 1910, 2(4):3-20.

Gilbert, M.W. and D.L. Clark (1983). Central Arctic Ocean paleoceanographic interpretations based on Late Cenozoic calcareous dinoflagellates. Marine Micropaleontology, $17: 385-401$.

Harland, R. (1983). Distribution maps of recent dinoflagellate cysts in bottom sediments from the North Atlantic Ocean and adjacent seas. Palaeontology, 26(2):321-387.

Honjo, S. (1976). Coccoliths: production, transportation and sedimentation. Marine Micropaleontology, 1:65-79.

Honjo, S., J.F. Connell and P.L. Sachs (1980). Deep ocean sediment trap; design and function of PARFLUX Mark 2. Deep-Sea Research, 27:745-753.

Honjo, S. (1980). Material fluxes and modes of sedimentation in the mesopelagic and bathypelagic zones. J. Marine Research, 38(1):53-97.

Kennett, J.P. (1982). Marine Geology. Prentice-Hall, Englewood Cliffs, New Jersey. 
Lister, T.R. (1970). A Monograph of the Acritarchs and Chitinozoa from the Wenlock and Ludlow Series of the Ludlow and Millichope Areas, Shropshire, Paleontographical Society, $124 \mathrm{pp}$.

Reid, P.C. (1975). A regional sub-division of dinoflagellate cysts around the British Isles. New Phytologist, 75:589-603.

Reid, P.C. (1978). Dinoflagellate cysts in the plankton. New Phytologist, 80:219-229.

Rossignol, M. (1964). Hystrichospheres du Quaternaire en Méditerranée orientale, dans les sédiments Pleistocenes et les boues marines actuelles. Revue de Micropaléontologie, 7:83-99.

Stover, L.E. and W.R. Evitt (1978). Analysis of Pre-Pleistocene organic walled dinoflagellates. Stanford University Publications, Geological Sciences, 15:1-300.

Tangen, K., L.E. Brand, P.L. Blackwelder and R.R.L. Guillard (1982). Thoracosphaera heimii (Lohmann) KAMPTNER is a Dinophyte: Observations on its morphology and life cycle. Marine Micropaleontology, 7(1982):193-212.

Taylor, F.J.R. (1976). Dinoflagellates from the International Indian Ocean Expedition. A report on material collected by the R.V. "Anton Bruun" 1963-1964. Bibliotheca Botanica, 132:1-234.

Turon, J.-L. (1980). Dinoflagellés et environment climatique. Les kystes de dinoflagellés dans les sédiments Récents de l'Atlantique nord-oriental et leurs relations avec l'environment océanique. Application aux dépots Holocènes du Chenal de Rockall. Mem. Mus. Hist. Nat., B27: 269-282.

Wall, D. (1965). Modern hystrichospheres and dinoflagellate cysts from the Woods Hole Region. Grana Palynologica, 6:279-314.

Wall, D. and B. Dale (1968a). Modern dinoflagellate cysts and evolution of the Peridiniales. Micropaleontology, 14:265-304.

Wall, D. and B. Dale (1968b). Quaternary calcareous dinoflagellates (Calciodinellidae) and their natural affinities. Journal of Paleontology, 42:1395-1408.

Wall, D. and B. Dale (1970). Living Hystrichosphaerid dinoflagellate spores from Bermuda and Puerto Rico. Micropaleongology, 16:47-58.

Wall, D., B. Dale, G.P. Lohmann and W.K. Smith (1977). The environmental and climatic distribution of dinoflagellate cysts in modern marine sediments from regions in the North and South Atlantic Oceans and adjacent seas. Marine Micropaleontology, 2:121-200.

Wall, D., R.R.L. Guillard, B. Dale, E. Swift and N. Watabe (1970). Calcitic resting cysts in Peridinium trochoideum (Stein) LEMMERMAN, an autotrophic marine dinoflagellate. Phycologia, 19:151-156. 
Williams, D.B. (1971). The occurrence of dinoflagellates in marine sediments. In: $M i$ cropalaeontology of Oceans, B.M. Funnell and W.R. Riedel (eds.), Cambridge University Press, Cambridge, pp. 231-243. 


\section{Plates}




\section{PLATE 1.1}

Light photomicrographs of dinoflagellate remains from deep sea sediment trap samples.

Scale bars $=10 \mu \mathrm{m}$.

1-10 Dinoflagellate theca: 5, 7, 9, 10 from Station E: $989 \mathrm{~m}$; others from Station E: $389 \mathrm{~m}$.

1 Blepharocystis sp.

2 Heteraulacus sp., apical view.

3 Ornithocercus sp.

4 Protoceratium cf. P. areolatum Kofoid, 1907

5 Dinophysis sp.

6 Protoperidinium sp.

7 cf. Gonyaulax polygramma Matzenauaer, 1933

8 ?Scrippsiella sp.

9 Scrippsiella cf. Scrippsiella trochoidea (Stein) A.R. Loeblich III, 1976 Apical view.

10 Ensiculifera sp., hypotheca with lance-like projection.

\section{1-12 Cladopyxis sp. (?cyst)}

11 Station E: $389 \mathrm{~m}$, with remains of cell contents.

12 Station E: 3,755 m, empty showing ?archeopyle.

\section{3-16 Calcareous cysts}

13 Calciodinellum operosum Deflandre, 1947, from Station E: 3,755 m, ventral view with operculum in place.

14 cf. Thoracosphaera albatrosiana Kamptner, 1963, from Station E: $989 \mathrm{~m}$.

15 cf. Thoracosphaera albatrosiana Kamptner, 1963, from Station E: 3,755 m, with operculum attached.

16 cf. Scrippsiella trochoidea (Stein) A.R. Loeblich III, 1976, from a plankton tow at $50 \mathrm{~m}$ depth off east coast U.S.A. $\left(33^{\circ} 45^{\prime} \mathrm{N}, 67^{\circ} 34^{\prime} \mathrm{W}\right)$.

17 View of prepared sediment from Station E: $989 \mathrm{~m}$, showing theca of Protoceratium cf. P. areolatum and cyst of Thoracosphaera albatrosiana.

18-20 Organic-walled cysts.

18 Protoperidinium sp., from Station E: $3,755 \mathrm{~m}$.

19 Protoperidinium conicoides (Paulsen) Balech, 1973, from bottom sediment at Station S.

20 Impagidinium sphaericum (Wall) Harland. 

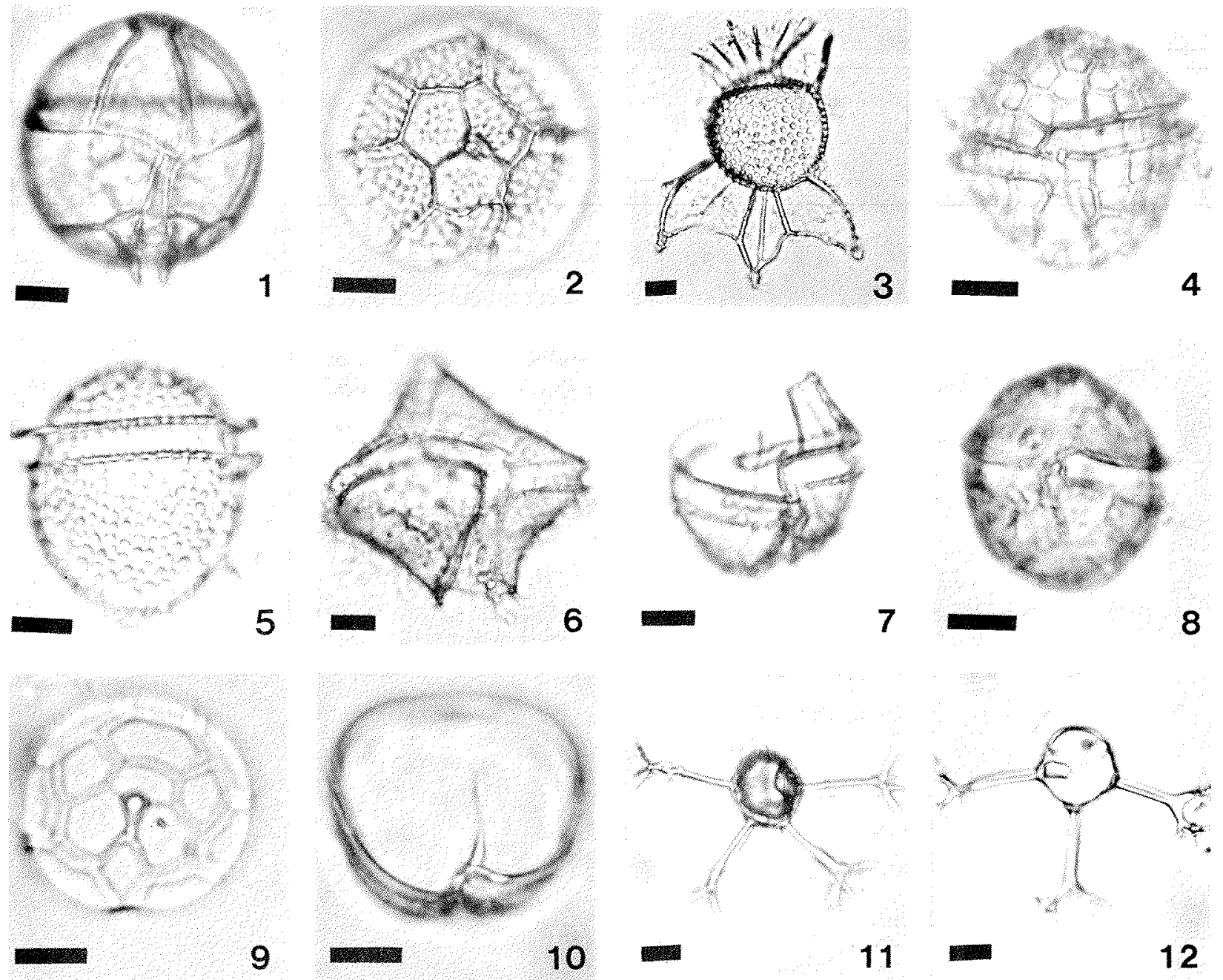

9
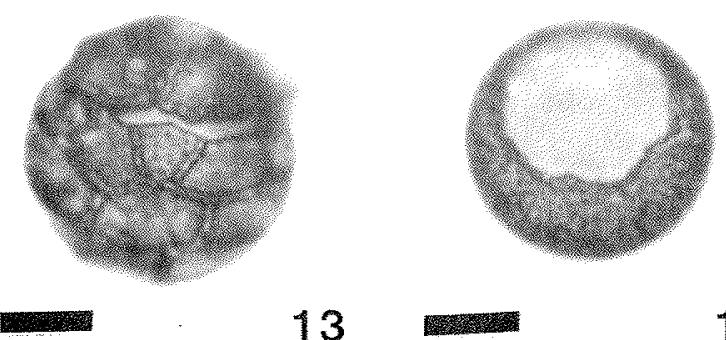

13
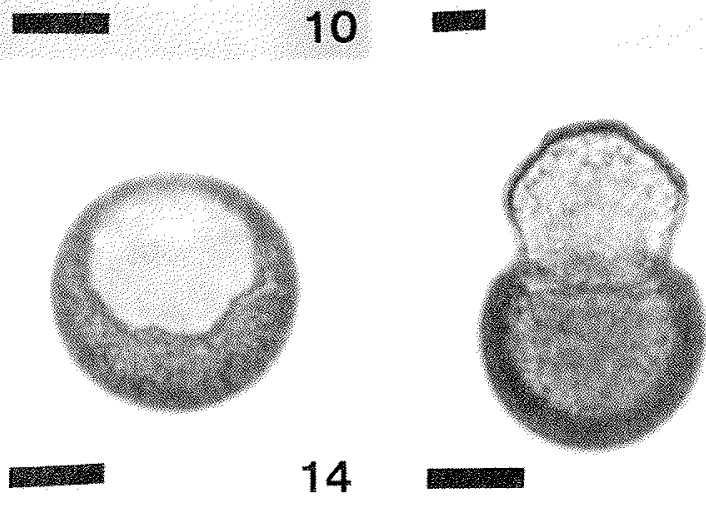

11

12
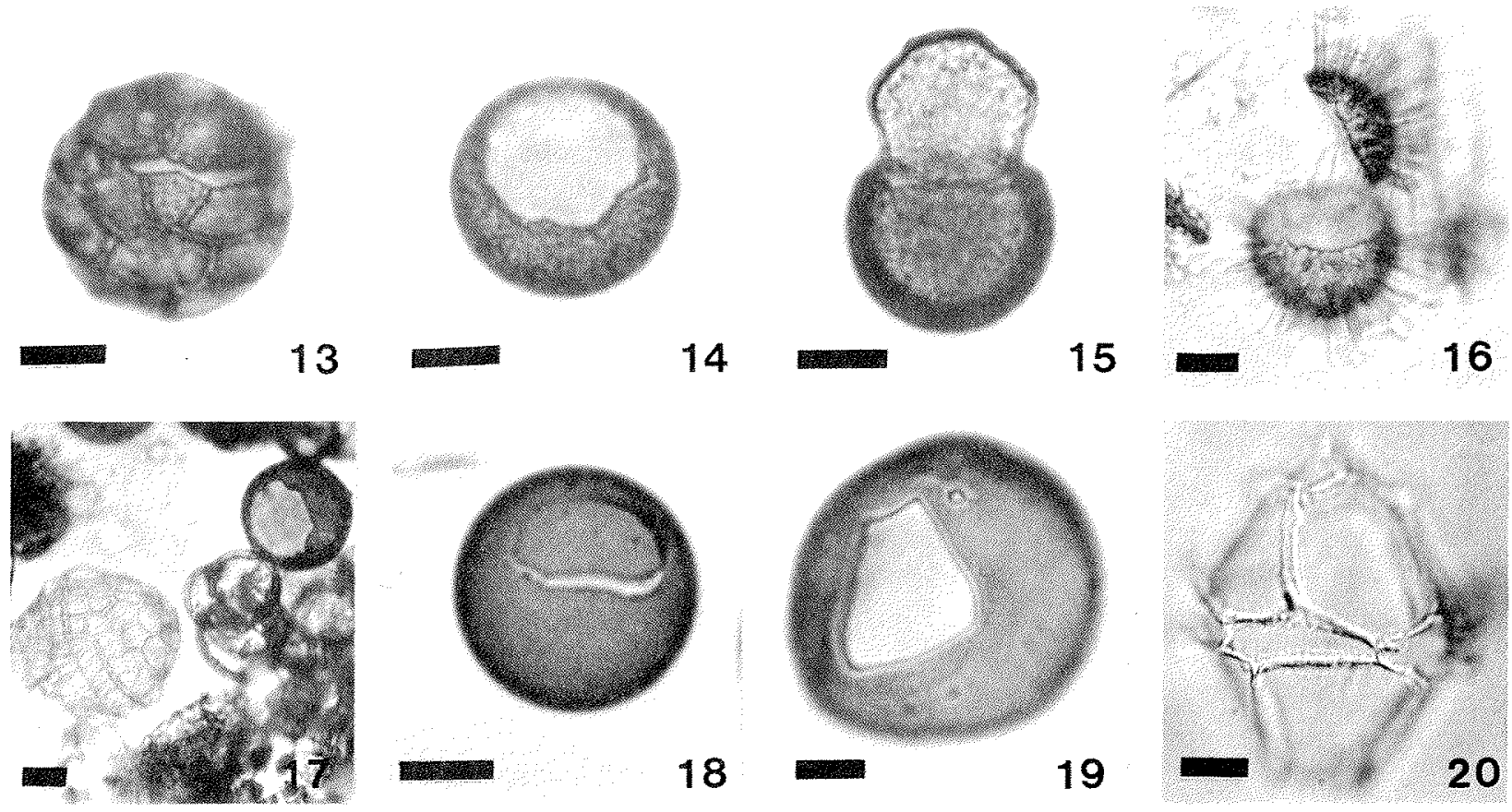

15

16

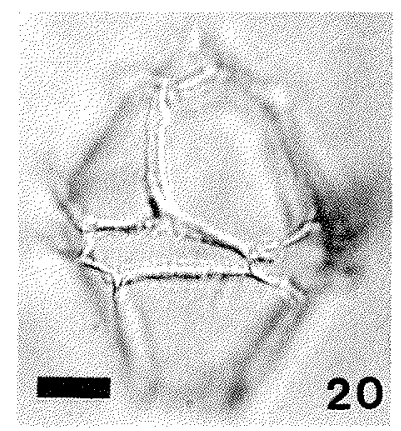




\section{PLATE 1.2}

SEM micrographs of Calciodinellum operosum Deflandre, 1947, from deep sea sediment trap samples.

Scale bars $=1 \mu \mathrm{m}$ in figures $4,8,13,16,20 ;$ others $=10 \mu \mathrm{m}$

1-4 Specimen from Station E: $988 \mathrm{~m}$

1-3 Tilted to show archeopyle.

4 Ultrastructural details.

5-8 Specimen with well developed parasutural ridges from Station $P_{1}: 2,778 \mathrm{~m}$.

5-7 Tilted to show archeopyle.

8 Ultrastructural details.

9-13 Specimen from Station E: $988 \mathrm{~m}$.

9 Antapical view.

10 Hypocyst in ventral view.

11 Ventral view.

12 Operculum: oblique ventro-apical view.

13 Operculum: details of apical parapore.

14-16 Specimen from Station PB: $667 \mathrm{~m}$.

17-20 Specimen with finer-grained ultrastucture from Station PB: $667 \mathrm{~m}$.

17 Antapical view.

18 Dorsal view.

19 Left lateral view.

20 Ultrastructural details. 

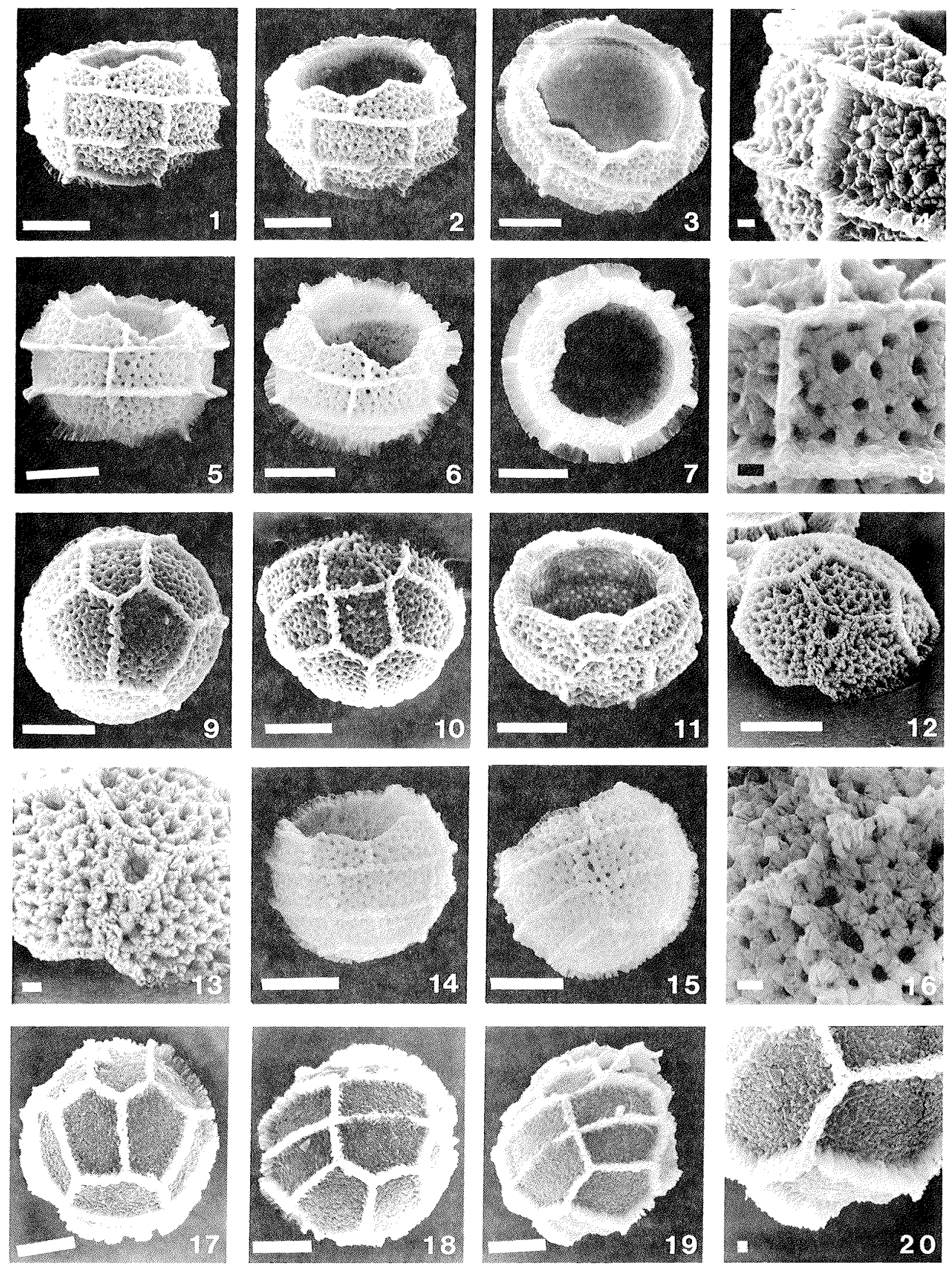


\section{PLATE 1.3}

SEM micrographs of other calcareous cysts from deep sea sediment samples.

Scale bars $=1 \mu \mathrm{m}$ in figures $4,7,8,11,12,14,16,19 ;$ others $=10 \mu \mathrm{m}$

1-8 Thoracosphaera albatrosiana Kamptner, 1963, sensu Fütterer, 1977

Specimen from Station E: $988 \mathrm{~m}$.

1, 2-4, 5, 6-7 Different specimens.

8 Operculum in place.

9-11 Thoracosphaera albatrosiana "granular form" sensu Fütterer, 1977 Specimen from Station E: $988 \mathrm{~m}$.

9 Tilted to show archeopyle.

11 Ultrastructural details.

12 Thoracosphaera albatrosiana Fütterer, 1977

Specimen from Station $\mathrm{P}_{1}: 2,778 \mathrm{~m}$, showing ultrastructural details.

13-19 ?Thoracosphaera tuberosa Kamptner, 1963, sensu Fütterer, 1977 From Station $\mathrm{P}_{1}$ : 2,778 m.

13-14, 15-16, 17, 18-19 Different specimens.

17 Shows operculum in place.

20 ? Calcareous cyst sp. with attached operculum

Specimen from Station $\mathrm{P}_{1}: 2,778 \mathrm{~m}$. 

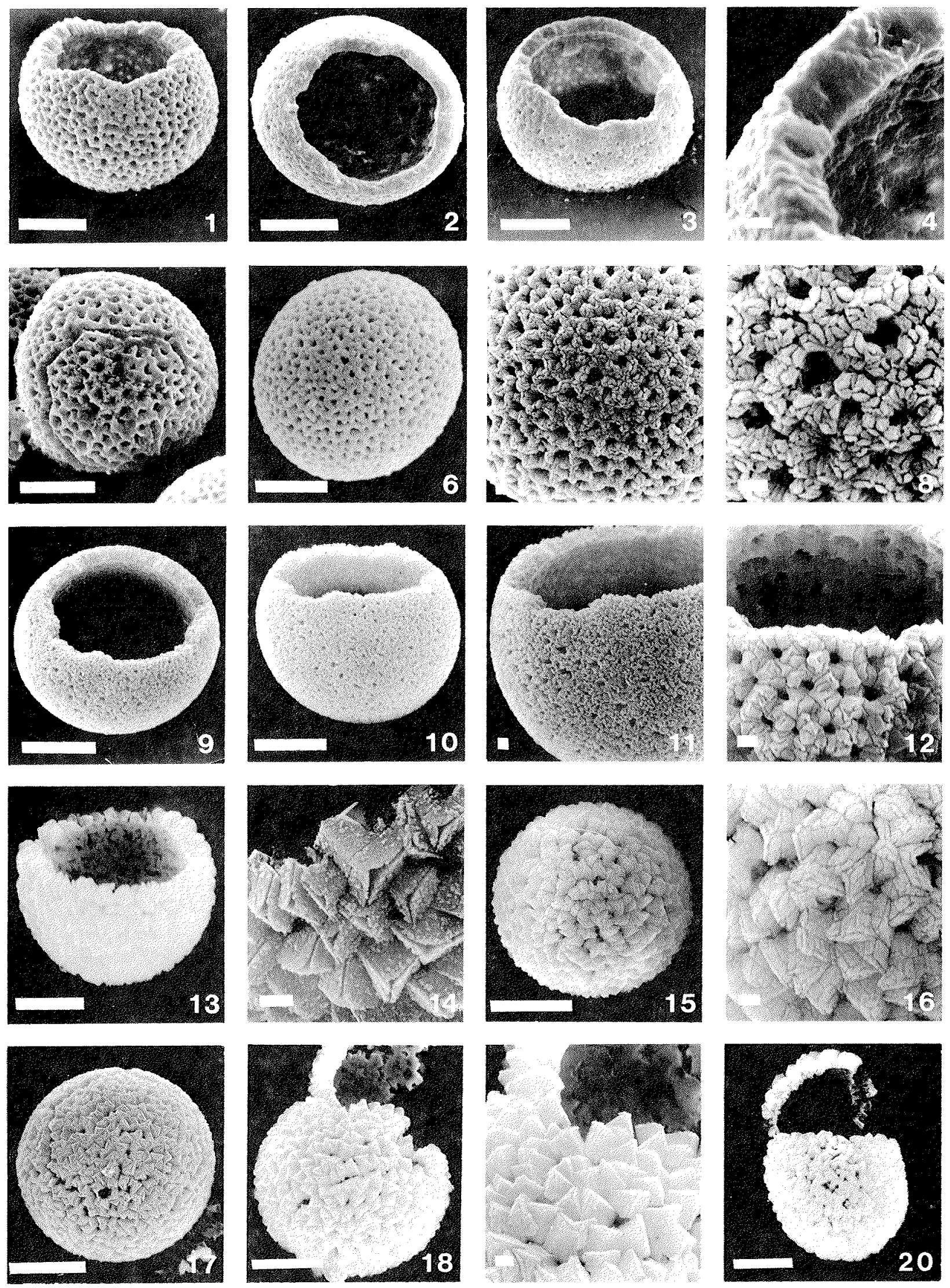


\section{PLATE 1.4}

SEM micrographs of dinoflagellate remains from deep sea sediment trap samples.

Scale bars $=1 \mu \mathrm{m}$ in figures $2,4,7,8,13,16,20 ;$ others $=10 \mu \mathrm{m}$

1-11 Scrippsiella cf. S. trochoidea (Stein) A.R. Loeblich III, 1976

From Station $\mathrm{P}_{1}: 2,778 \mathrm{~m}$.

1-2, 3-4, 5-8, 9, 10, 11 Different specimens.

4, 7 Ultrastructural details on outside surface.

8 Ultrastructural details on inside surface.

10 Free operculum (inside view).

11 Operculum in place.

12-13 ? Calcareous cyst sp. from Station $\mathrm{P}_{1}: 2,778 \mathrm{~m}$.

14-16 Cladopyxis sp. (?cyst) from Station E: $988 \mathrm{~m}$.

14, 15 Different orientations.

16 Details of ?archeopyle.

17-20 Protoceratium cf. P. areolatum Kofoid, 1907

Theca from Station PB: $667 \mathrm{~m}$.

20 Evidence of corrosion. 

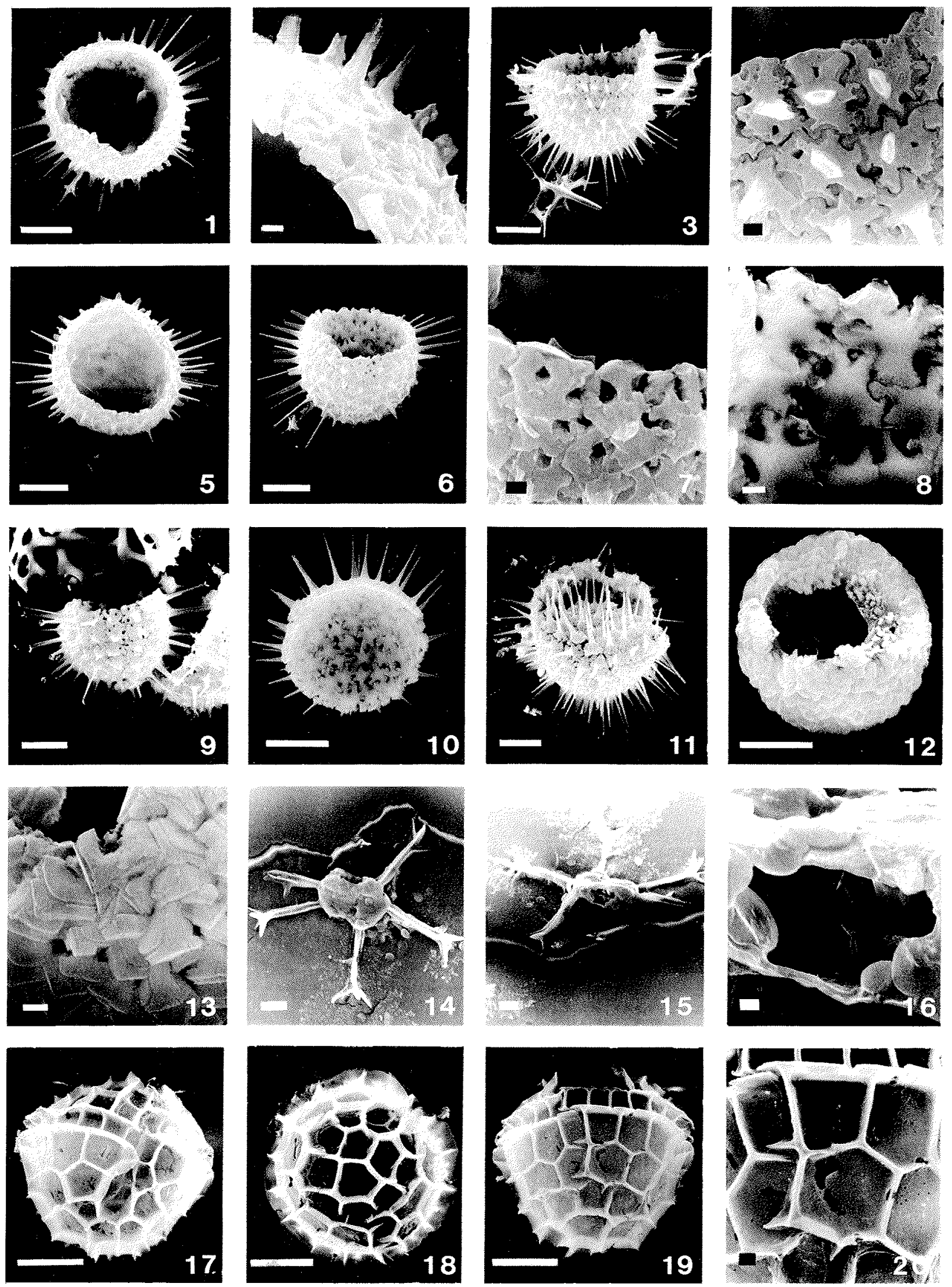


\title{
Chapter 2
}

\section{Thoracosphaerids: Pelagic Fluxes}

\author{
Barrie Dale
}

\section{Abstract}

For the first time, biocoenosis of thoracosphaerids was described in several deep ocean sediment trap samples. Two main types were recorded from both the Pacific and Atlantic oceans, Thoracosphaera heimii and T. granifera. Their distribution in trap samples suggests a steady, abundant flux through the water column of up to more than $30,000 \mathrm{~m}^{-2}$ day-1, roughly ten times greater than the flux of dinoflagellate cysts. This supports recent biological observations suggesting that thoracosphaerids are calcareous shells of vegetative cells reproducing by simple binary fission rather than resting cysts produced less frequently by vegetative cells. As the only fossilizable vegetative cells, thoracosphaerids potentially represent the most direct geological record of dinoflagellate productivity in the oceanic realm.

\section{Introduction}

Several types of thoracosphaerids (i.e., small calcareous spheres referable to the genus Thoracosphaera Kamptner, 1927) were observed in deep-sea sediment trap samples. As in most previous studies, they are reported here as a distinctive group of microfossils, though Tangen et al. (1982) demonstrated the dinoflagellate affinities of thoracosphaerids. The more familiar thecal remains and resting cysts of other dinoflagellates, which were the main focus of this investigation, are reported in Chapter 1 , this volume.

Thoracosphaerids have a long phylogenetic history, at least through the Cretaceous (Fütterer, 1977), possibly even back to the Triassic (Jafar, 1979). They have been reported both from Atlantic and Pacific bottom sediments and from the plankton of most major oceans (Tangen et al., 1982). So far, only the type species Thoracosphaera heimii (Lohmann) Kamptner has been studied in culture (Tangen et al., 1982).

The complete life cycle of $T$. heimii has not yet been described, but observations by Tangen et al. (1982) suggest this to be fundamentally different from other known dinoflagellates. Of particular interest to geology is the fact that the calcareous sphere is a shell for the vegetative organism and not a cyst wall as in almost all other known fossil dinoflagellates 
Table 2.1: Summary of station data and samples used for thoracosphaerid studies.

\begin{tabular}{|c|c|c|c|}
\hline Station & PARFLUX $S_{1,2}$ & PARFLUX $\mathbf{P}_{1}$ & PARFLUX PB $_{1}$ \\
\hline Location & $\begin{array}{l}31^{\circ} 32.5^{\prime} \mathrm{N} \\
55^{\circ} 55.4^{\prime} \mathrm{W}\end{array}$ & $\begin{array}{l}15^{\circ} 21.1^{\prime} \mathrm{N} \\
151^{\circ} 28.5^{\prime} \mathrm{W}\end{array}$ & $\begin{array}{l}05^{\circ} 21^{\prime} \mathrm{N} \\
81^{\circ} 53^{\prime} \mathrm{W}\end{array}$ \\
\hline Ocean/Basin & $\begin{array}{c}\text { Central } \\
\text { Sargasso Sea/ } \\
\text { Söhm } \\
\text { Abyssal Plain }\end{array}$ & $\begin{array}{c}\text { N. Central } \\
\text { Pacific/ } \\
\text { E. Hawaii } \\
\text { Abyssal Plain }\end{array}$ & $\begin{array}{c}\text { Tropical } \\
\text { Pacific/ } \\
\text { hemipelagic } \\
\text { Panama Basin }\end{array}$ \\
\hline Term & $10 / 76-1 / 77$ & $7 / 78-11 / 78$ & $8 / 79-12 / 79$ \\
\hline Duration & 75 days & 98 days & 112 days \\
\hline $\begin{array}{l}\text { Trap Depth } \\
\text { (m) }\end{array}$ & $\begin{array}{c}(372) \\
976^{a} \\
3,694^{a} \\
5,206 \\
5,367^{a}\end{array}$ & $\begin{array}{r}378 \\
978 \\
2,778^{a} \\
4,280^{a} \\
5,582^{a}\end{array}$ & $\begin{array}{c}667^{a} \\
1,268 \\
(2,265) \\
2,869^{a} \\
3,769^{a}\end{array}$ \\
\hline Ocean Depth & $5,581 \mathrm{~m}$ & $5,792 \mathrm{~m}$ & $3,856 \mathrm{~m}$ \\
\hline
\end{tabular}

aSamples used for thoracosphaerid studies. Trap samples represented aize fraction $<63 \mu \mathrm{m}\left(<250 \mu \mathrm{m}\right.$ in $\left.S_{3,5,6,9}\right)$.

(siliceous endoskeletal structures in Actiniscus may be an exception). Thoracosphaerids thus represent the only known fossil vegetative stages within the Dinophyceae seen in trap samples, potentially offering a more direct record of the organism's productivity. For example, up to one division of the organism per day was observed in culture, producing two thoracosphaerids, whereas probably relatively few individuals in a population produce the resting cysts making up the bulk of the dinoflagellate fossil record (Dale, 1983).

Tangen et al. (1982) showed that surprisingly large amounts of thoracosphaerids were produced during culture experiments under certain conditions, but no quantitative data on actual production in the oceans was available. Results are presented here of a first attempt to document both qualitatively and quantitatively the thoracosphaerids contributed from oceanic plankton to the present day deep-sea sediment flux. The samples studied here from large sediment traps placed at different depths in the deep sea provided a unique opportunity to supplement previous information from the two extremes of surface plankton catch and bottom sediment analysis.

\section{Materials and Methods}

\section{Samples}

Figure 1.1 shows the location of sediment trap stations, and Table 2.1 summarizes the station data for samples studied for thoracosphaerids. Details of the sediment traps, their deployments, and the collection and subdivision of samples obtained from them is reported 
by Honjo (1980). Samples from station PB represented 1/64 of the original trap samples; others were 1/32. A total of 11 samples from three trap stations were examined for thoracosphaerids.

\section{Sample Preparation and Examination}

The work was carried out in two phases. The first batch of samples (from the Atlantic Station S) was examined in 1979 as part of a pilot project to assess the value of this type of sample for dinoflagellate studies. Results from this were encouraging, and in 1981 the study was extended to include samples from the Pacific stations $\mathrm{P}_{1}$ and $\mathrm{PB}$.

Initially, the samples were prepared for dinoflagellate cyst studies; thoracosphaerids were investigated later (phase 2). Two main problems were encountered in trying to document thoracosphaerids in the sediment trap samples: 1) diagnostic morphologic features of thoracosphaerids (e.g., crystalline structure of the wall) could not be resolved by light microscopy, necessitating the use of scanning electron microscopy (SEM); 2) valid quantitative counts for thoracosphaerids could not be made from SEM preparations, due to the "diluting" effect of large amounts of other material in the samples.

The following standard procedure was followed to obtain both qualitative and quantitative information for dinoflagellate remains in the trap samples:

1. After thoroughly shaking to homogenize the sample in original sea-water, a known amount was wet-sieved with a mesh size of $25 \mu \mathrm{m}$, routinely used for concentrating dinoflagellate cysts.

2. The size fraction greater than $25 \mu \mathrm{m}$ retained in the sieve was counted for particles of identifiable dinoflagellate origin, using normal light microscopy. In phase 1 of the project, counting was done from open drops on microscope slides (allowing manipulation of specimens), but in phase 2 permanent mounts in glycerine jelly ringed with beeswax were used. Counts were expressed (as in Honjo, 1980) as a daily flux in a square meter section of water column at a given trap (Table 2.2). This was calculated by dividing the total flux by the number of days the trap was deployed and the $1.5 \mathrm{~m}^{2}$ area of the trap opening.

3. The size fraction less than $25 \mu \mathrm{m}$ was spot-checked microscopically, to see if significant dinoflagellate remains were being lost from the counts, before being permanently mounted in reference slides.

4. In phase 2 of the project it was decided (for reasons explained later) to include estimates of thoracosphaerids, most of which were too small to be included in the $>25 \mu \mathrm{m}$ fraction. These and the larger calcareous cysts (Chapter 1, this volume) were counted in one wet slide preparation of untreated sample (generally giving counts of 100-300). The relative proportions of thoracosphaerids to calcareous cysts thus obtained was used to estimate fluxes for thoracosphaerids based on comparison with calcareous cyst fluxes obtained from the quantitative counts of the $>25 \mu \mathrm{m}$ fraction (point 2 above).

5. Sample material not used for the quantitative count was used for detailed morphological studies of the various types encountered. For this, individuals were picked off 
Table 2.2: Fluxes of thoracosphaerids and total dinoflagellate cysts.

\begin{tabular}{|c|c|c|c|c|c|c|}
\hline \multirow{2}{*}{\multicolumn{3}{|c|}{$\begin{array}{l}\text { Station: } \\
\text { and } \\
\text { Depth (m) }\end{array}$}} & \multicolumn{2}{|c|}{ Thoracosphaerids $^{\dagger}$} & \multicolumn{2}{|c|}{ Total Flux (m²/day) } \\
\hline & & & $\mathbf{1}$ & 2 & Thoracs. & cysts \\
\hline S: & 3, & & $\begin{array}{l}?^{\ddagger} \\
? \\
?\end{array}$ & $\begin{array}{l}313 \\
768 \\
512\end{array}$ & $\begin{array}{l}313 \\
768 \\
512\end{array}$ & $\begin{array}{l}6,002 \\
8,704 \\
2,560\end{array}$ \\
\hline$P_{1}:$ & $\begin{array}{l}2, \\
4, \\
5,\end{array}$ & & $\begin{array}{r}19,391 \\
14,125 \\
2,352\end{array}$ & - & $\begin{array}{r}19,391 \\
14,125 \\
2,352\end{array}$ & $\begin{array}{r}1,968 \\
1,567 \\
401\end{array}$ \\
\hline $\mathrm{PB}_{1}:$ & & $\begin{array}{l}67 \\
68 \\
69 \\
69 \\
61\end{array}$ & $\begin{array}{l}30,706 \\
29,338 \\
33,711 \\
35,733 \\
24,024\end{array}$ & $\begin{array}{r}91 \\
61 \\
107 \\
91 \\
25\end{array}$ & $\begin{array}{l}30,797 \\
29,399 \\
33,818 \\
35,824 \\
24,049\end{array}$ & $\begin{array}{l}2,422 \\
2,590 \\
2,926 \\
3,916 \\
2,667\end{array}$ \\
\hline$\dagger$ & $?$ & - & $\begin{array}{l}\text { Small tho } \\
\text { Larger th } \\
\text { Not count }\end{array}$ & $\begin{array}{l}\text { haerids } \\
\text { phaerid }\end{array}$ & ext for for & luded). \\
\hline
\end{tabular}

with a micropipette, and coated with gold using standard SEM preparation methods. Permanent reference slides were made of the $>25 \mu \mathrm{m}$ fraction remaining after these studies.

\section{The Organisms Recorded}

\section{Thoracosphaerideae}

The true systematic position of calcareous plankters included in the genus Thoracosphaera Kamptner, 1971, has long been under debate. Generally, they were classified as coccolithophorids or incertae sedis. Fütterer (1976) suggested they were calcareous dinoflagellate cysts closely related to Calciodinellum and related genera. This hypothesis was based on "the continuous transition, in skeletal architecture and ultrastructure, between Thoracosphaera albatrosiana and Calciodinellum operosum" (Fütterer, 1976, p. 11).

Based on morphologic criteria generally used to identify dinoflagellate cysts (Chapter 1 , this volume), thoracosphaerids so far described in the literature include at least two distinct types. A few, such as T. albatrosiana, certainly show angularly-shaped archeopyles, indicating paraplate affinities, but the proportionally smaller openings in others, including the type species T. heimii Kamptner, are strikingly circular ("pylomes"). Not all dinoflagellate cysts show paraplate-shaped archeopyles (e.g., the simple split, or irregularly-shaped archeopyles of unarmored forms), and the archeopyles of several known calcareous cysts are nearly circular. Despite the similarities in crystalline ultrastructure noted by Fütterer $(1976,1977)$, an alternative morphological interpretation of this group is presented here: that thoracosphaerids sensu stricto, small calcispheres with distinctly circular pylomes, are 
a separate group, not closely related to calcareous cysts such as Calciodinellum operosum. Obvious dinoflagellate cysts with distinctive archeopyles presently accommodated within the genus Thoracosphaera (e.g., T. albatrosiana) are not considered to be cogeneric with Thoracosphaera s.s. Ultimately, they should be removed from this genus.

At the start of this study the affinities of thoracosphaerids s.s. were regarded as unproven and they were not counted (except larger forms, Station S) in phase 1 samples. Tangen et al. (1982) isolated T. heimii in culture and observed its life cycle and ultrastructure during ontogeny. Results to date have shown that the calcareous spheres are not resting cysts, but a vegetative stage in a hitherto unknown type of dinoflagellate life cycle so distinctive that Tangen created a new order, Thoracosphaerales (Tangen et al., 1982). The fact that thoracosphaerids represent a fundamentally different type of dinoflagellate probably accounts for the ultrastructural similarities and apertural differences between thoracosphaerids and calcareous dinoflagellate cysts.

Thoracosphaerids recorded in phase 2 samples are discussed below:

Thoracosphaera heimii (Lohmann) Kamptner, 1927, sensu Fütterer, 1977 (Plate 2.1, figures 1-12). In light microscopy two types of small thoracosphaerids (9-20 $\mu \mathrm{m}$ diameter) were often distinguished, a smooth surface form and a more coarsely sculptured form. SEM studies showed the latter to be T. heimii. Some of the large range of skeletal variation reported by Fütterer (1977) was seen, but not the extremely diagenetically altered forms. Otherwise, specimens in this study agreed with the description by Fütterer (1977).

Occasionally, larger thoracosphaerids $(25-30 \mu \mathrm{m})$ were seen which resemble $T$. heimii in SEM details of ultrastructure (Plate 2.1, figures 11, 12). These were counted separately, and may represent a distinct form.

Thoracosphaera granifera Fütterer, 1977 (Plate 2.1, figures 13-20). The smooth form of small thoracosphaerids seen in light microscopy was identified with the help of SEM as T. granifera. This was counted together with T. heimii as small thoracosphaerids.

\section{Results and Discussion}

\section{Fluxes of Thoracosphaerids}

Counts of thoracosphaerids are presented in Table 2.2. Most of these were small calcareous spheres (10-20 $\mu \mathrm{m}$ diameter) of Thoracosphaera heimii or T. granifera. They were roughly ten times more abundant than dinoflagellate cysts at Stations $\mathrm{P}_{1}$ and $\mathrm{PB}$. Though total thoracosphaerids were not estimated for Station $S$, many were observed incidentally and they are presumed to be similarly abundant at this station. The preservability of these thoracosphaerids and their ultimate contribution to bottom sediments probably closely parallels that discussed for calcareous cysts (Chapter 1, this volume). If not removed by dissolution, they may contribute significantly to bottom sediments, as witnessed by a fossil record from at least Cretaceous to present.

In general, distribution of thoracosphaerids seen in trap samples suggests a steady abundant flux of these through the water column. Their much greater rate of production than dinoflagellate cysts is consistent with the work of Tangen et al. (1982), suggesting that 
these are vegetative stages (produced more often by normal vegetative cell division) rather than resting cysts (produced less frequently by a population of vegetative cells).

\section{Comparisons between Stations}

Total flux of cysts and thoracosphaerids suggests that the stations may be ranked as follows according to their reflected productivity (from highest to lowest): $\mathrm{S}, \mathrm{PB}$, and $\mathrm{P}_{1}$. This does not agree with the ranking of general biogenic flux, which ranks PB as the largest, followed by $S$ and $P_{1}$ (Honjo et al., 1982).

\section{Phylogeny of the Morphology of Thoracosphaerids}

Tangen et al. (1982) postulated that the cyst-like calcareous shell housing vegetative stages of T. heimii may have evolved from cysts in phylogenetic ancestors of the species. They reasoned that there may be selective pressures for a phylogenetic lineage to reduce or eliminate its cyst stage so as to not lose a large percentage of the population to cysts sinking too deeply below the plankton.

The main part of the present study has revealed characteristic fluxes of calcareous dinoflagellate cysts in the open oceans. Several of these cysts have long phylogenetic histories within the oceanic realm, suggesting that at least they have survived any such selective pressure against cyst formation. Furthermore, they appear to provide part of a life cycle which may well combine a sinking strategy in the cyst with a motile strategy in the vegetative stage. Dale (Chapter 1 , this volume) has suggested that possible advantages gained by including a sinking-stage may include removing the cell from relatively higher levels of predation in the biologically more active photic zone, and gaining access to nutritionally richer waters usually found slightly deeper in the water column.

Tangen et al. (1982) also suggested a possible alternative hypothesis for the presence of the calcareous wall in thoracosphaerids: that it may not be a phylogenetic relict but rather have evolved independently by providing some selective advantage. If, as postulated here, at least some cyst-forming oceanic dinoflagellates may have evolved a successful life cycle combining some of the possible advantages enjoyed by mineralized "sinking" plankters (e.g., diatoms) with those more characteristic for "swimming" plankters (e.g., dinoflagellates), thoracosphaerids may represent a variation of this general theme.

Morphology of the motile stage of $T$. heimii adds indirect support for the independent evolution of the calcareous wall. Both living dinoflagellates known to produce calcareous resting cysts and those fossil calcareous cysts showing diagnostic morphology suggest that calcareous cysts have generally been produced by a closely related group belonging to the Peridiniales. These are thecate dinoflagellates represented by the genera Scrippsiella and Ensiculifera. Even if such dinoflagellates had converted the calcareous cyst stage into an actively metabolizing vegetative stage, the associated motile stage in the life cycle may have been expected to retain its basic thecate form. However, the motile stage of $T$. heimii is a Gymnodinium-like athecate dinoflagellate. 


\section{Conclusions}

1. Thoracosphaerids are recognized as a morphologically distinct group of microfossils; they are comprised of small calcareous spheres with a characteristically circular opening (pylome) which is relatively smaller than the usually more angular archeopyles of calcareous dinoflagellate cysts.

2. Obvious dinoflagellate cysts presently included in the genus Thoracosphaera (e.g., Thoracosphaera albatrosiana Kamptner, 1963) are not considered to be cogeneric with Thoracosphaera s.s. and therefore should be reclassified with other calcareous cystforming dinoflagellates within the Peridiniales.

3. Thoracosphaerids represent the calcareous shells of vegetative cells of a distinct group of dinoflagellates within the new order Thoracosphaerales Tangen.

4. Two main types of thoracosphaerids were recorded here from the Pacific and Atlantic oceans: T. heimii and T. granifera.

5. Fluxes of more than 30,000 thoracosphaerids $/ \mathrm{m}^{2} /$ day were recorded. This was roughly ten times greater than the flux of dinoflagellate cysts, reflecting the basic difference between thoracosphaerids produced more often by vegetative cell division and resting cysts produced less frequently by a population of vegetative cells.

\section{Acknowledgments}

I wish to thank Dr. Susumu Honjo for inviting my participarion in the PARFLUX project and for his enthusiastic encouragement throughout the work reported here. Technical assistance of Dr. Kozo Takahashi with part of the SEM work and of Robert Williams with photographic printing is also gratefully acknowledged. Financial support for the sample collecting program was provided by NSF grants OCE-76-82036, OCE-77-27004, and OCE-79-25429.

\section{References}

Dale, B. (1983). Dinoflagellate resting cysts: "benthic plankton". In: Survival Strategies of the Algae, G.A. Fryxell (ed.), Cambridge University Press, New York, pp. 69-136.

Fütterer, D. (1976). Kalkige Dinoflagellaten ("Calciodinelloideae") und die systematische Stellung der Thoracosphaerideae. N. Jb. Geol. Paleontol. Abhl, 151: 119-141.

Fütterer, D. (1977). Distribution of calcareous dinoflagellates in Cenozoic sediments of Site 366, Eastern North Atlantic. In: Y. Lancelot, E. Siebold, et al., Initial Reports of the Deep Sea Drilling Project, Vol. 41, U.S. Government Printing Office, Washington, D.C., pp. 709-737.

Honjo, S. (1980). Material fluxes and modes of sedimentation in the mesopelagic and bathypelagic zones. Journal of Marine Research, 38(1):53-97. 
Jafar, S.A. (1979). Taxonomy, stratigraphy, and affinities of calcareous nannoplankton genus Thoracosphaera Kamptner. Proceedings of the IV $V^{\text {th }}$ International Palynology Congress, 2: 1-21.

Kamptner, E. (1927). Beitrag zur Kenntnis adriatischer Coccolithophoriden. Arch. Protistenk., 58:173-184.

Tangen, K., L.E. Brand, P.L. Blackwelder and R.R.L. Guillard (1982). Thoracosphaera heimii (Lohmann) Kamptner is a Dinophyte: Observations on its morphology and life cycle. Marine Micropaleontology, 7:193-212. 


\section{Plate}




\section{PLATE 2.1}

SEM micrographs of Thoracosphaerids from deep sea sediment trap samples.

Scale bars $=10 \mu \mathrm{m}$ in figures $13,14,17,18$; others $=1 \mu \mathrm{m}$

1-12 Thoracosphaera heimii (Lohmann) Kamptner, 1920, sensu Fütterer, 1977

11, 12 are larger forms mentioned in the text.

1-5 from Station PB: $667 \mathrm{~m}$.

6-12 from Station $\mathrm{P}_{1}: 2,778 \mathrm{~m}$.

1-3, 4-5, 6-7, 8-9, 10, 11, 12 are different specimens.

13-20 Thoracosphaera granifera Fütterer, 1977

13-16, 20 from Station PB: $667 \mathrm{~m}$.

17-19 from Station E: $988 \mathrm{~m}$.

$13,14,16,17-19,20$ are different specimens.

20 shows details of ultrastructure from the inside of a broken specimen. 

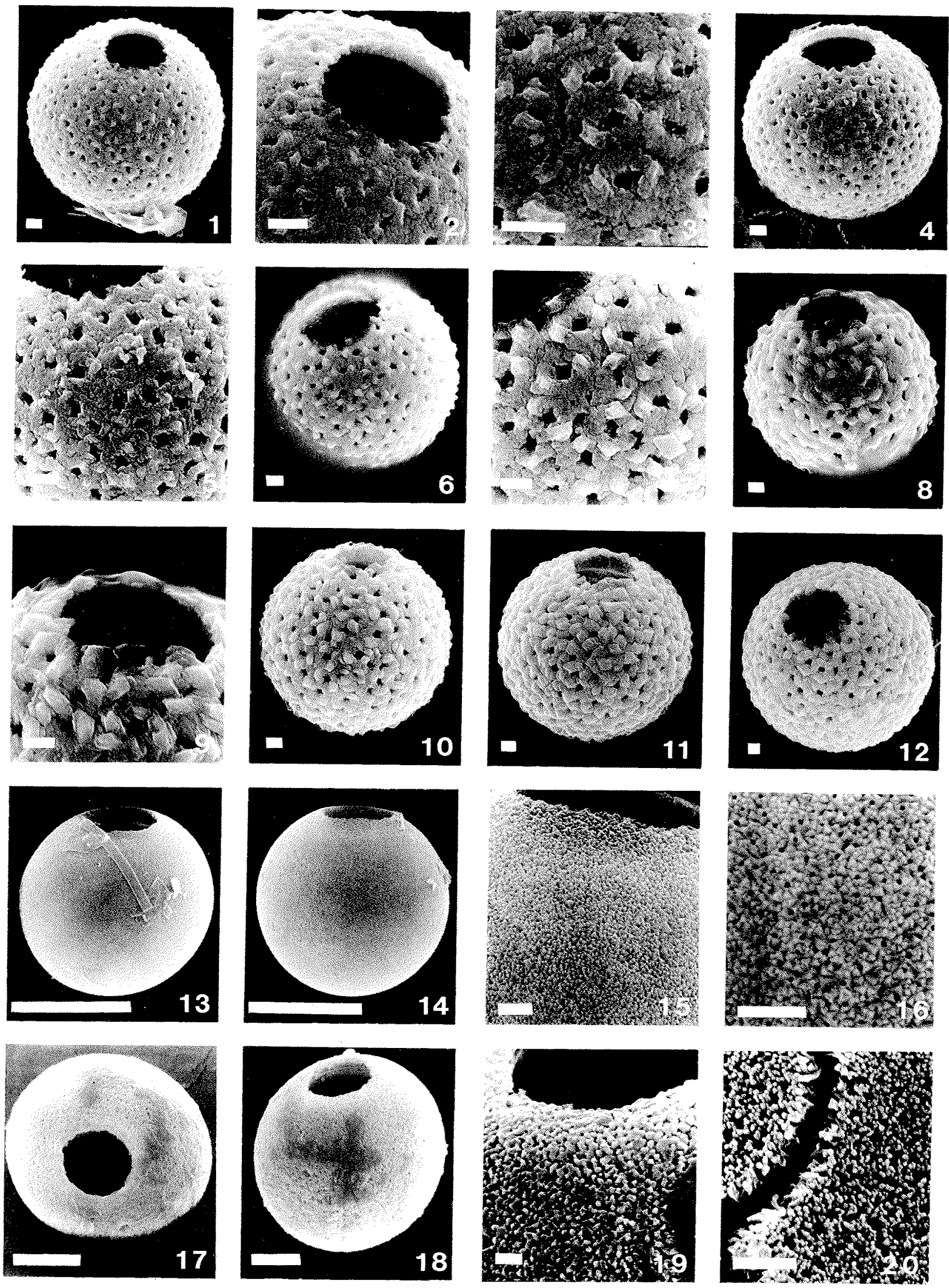


\title{
Chapter 3
}

\section{Dinoflagellate Contributions to the Sediment Flux of the Nordic Seas}

\author{
Amy L. Dale and Barrie Dale
}

\section{Abstract}

The Nordic Seas region connects the largely ice-free Northeast Atlantic Ocean and the partially ice-covered Arctic, and thus is characterized by strongly contrasting oceanic conditions within a relatively small sedimentary basin. The Norwegian Atlantic Current carries relatively warmer water northward along the eastern side, while the East Greenland Current carries relatively colder water southward along the western side of the basin. From 1983 to 1989 , ninety-three time-series sediment trap samples were recovered from seven stations in the Nordic Seas. Each sample represents two weeks to one month of sedimentation at approximately 400 meters above the seafloor, in 2,000-3,500 meter water depth. The results of dinoflagellate analysis of 63 of these samples are reported here. The main objective was to investigate the nature of the dinoflagellate flux in this high latitude region, and to assess the potential for using dinoflagellate cysts as tracers of water masses and sediment transport within the Nordic Seas.

Dinoflagellate cysts were recorded at all stations, with average fluxes ranging from 76 to $469 \mathrm{cysts} / \mathrm{m}^{2} /$ day. Cyst fluxes were higher (more than two-fold) for stations located in the relatively warmer Norwegian Atlantic Current than for stations located in the East Greenland Current. Diversity also was higher: 14-16 species, as compared with 6-10 species for stations in the East Greenland Current. Assemblages included some species clearly carried into the region from the North Atlantic Ocean (most notably, spherical calcareous cysts), and a number of coastal forms previously documented from the surrounding continental shelves. At least one oceanic form, Impagidinium pallidum, is thought to be endemic to the Greenland Sea. Cyst fluxes were comprised mainly of organic-walled forms, with only minor contributions by calcareous cyst types. This contrasts sharply with previous findings for the Equatorial Atlantic and Pacific Oceans and the Panama Basin, where calcareous cysts 
predominated. Two examples of transport were documented: a sudden massive occurrence of recycled Early Miocene cysts, thought to be caused by a turbidity flow from the Lofoten Shelf, and large amounts of one cyst species, Peridinium faeroense, occurring in sediments believed to be transported from the Barents Shelf.

\section{Introduction}

The Nordic Seas include the Greenland Sea, the Norwegian Sea, and the western edge of the Barents Sea (Figure 3.1). They comprise the largest oceanic passageway between the mainly ice-free Northeastern Atlantic Ocean and the mainly ice-covered Arctic Ocean. As such, they represent a major area of heat exchange between the North Atlantic and the Arctic regions, and this produces strongly contrasting oceanic conditions within one relatively small sedimentary basin. The near surface hydrography is heavily influenced by the warmer, Norwegian Atlantic Current on the eastern side (approximate temperature range: $3-11^{\circ} \mathrm{C}$ ), and by the colder, East Greenland Current on the western side (approximate temperature range: $-1-4^{\circ} \mathrm{C}$ ).

Between 1983 and 1989, seven deep sea time-series sediment traps were strategically deployed to cover the main water masses of the Nordic Seas basin, as part of a joint U.S./German program to study high latitude sedimentation. Samples from these are being analyzed for dinoflagellates, and the results from the five stations completed so far are reported here. The main objective is to investigate the nature of the dinoflagellate flux in this region, and to assess the potential for using dinoflagellate cysts as tracers of water masses and sediment transport. Whereas first studies of oceanic dinoflagellates (Dale, 1986; Chapters 1 and 2, this volume) investigated fluxes from individual stations in the Pacific and Atlantic oceans, the present study represents a basin-wide analysis of the dinoflagellate flux from one region. The varied hydrography of the Nordic Seas, together with the extensive background data already developed by Dale and co-workers for coastal dinoflagellates from this region, provided an optimum framework for assessing the relationship between dinoflagellates sedimenting out from the water column, and the overlying surface waters.

This study builds upon first investigations of oceanic dinoflagellates from sediment traps in the Equatorial Atlantic Ocean, Central Pacific Ocean and the Panama Basin, and extends these to include the Nordic Seas. Here, we present a full account of the dinoflagellate cyst flux from five stations in the Nordic Seas, and compare these with results from the other regions. A full assessment of what seems to be an excellent potential for using dinoflagellate cysts as tracers of water masses and sediment transport, and of the implications of this for paleoceanography, will be presented in a subsequent paper upon completion of the study. 


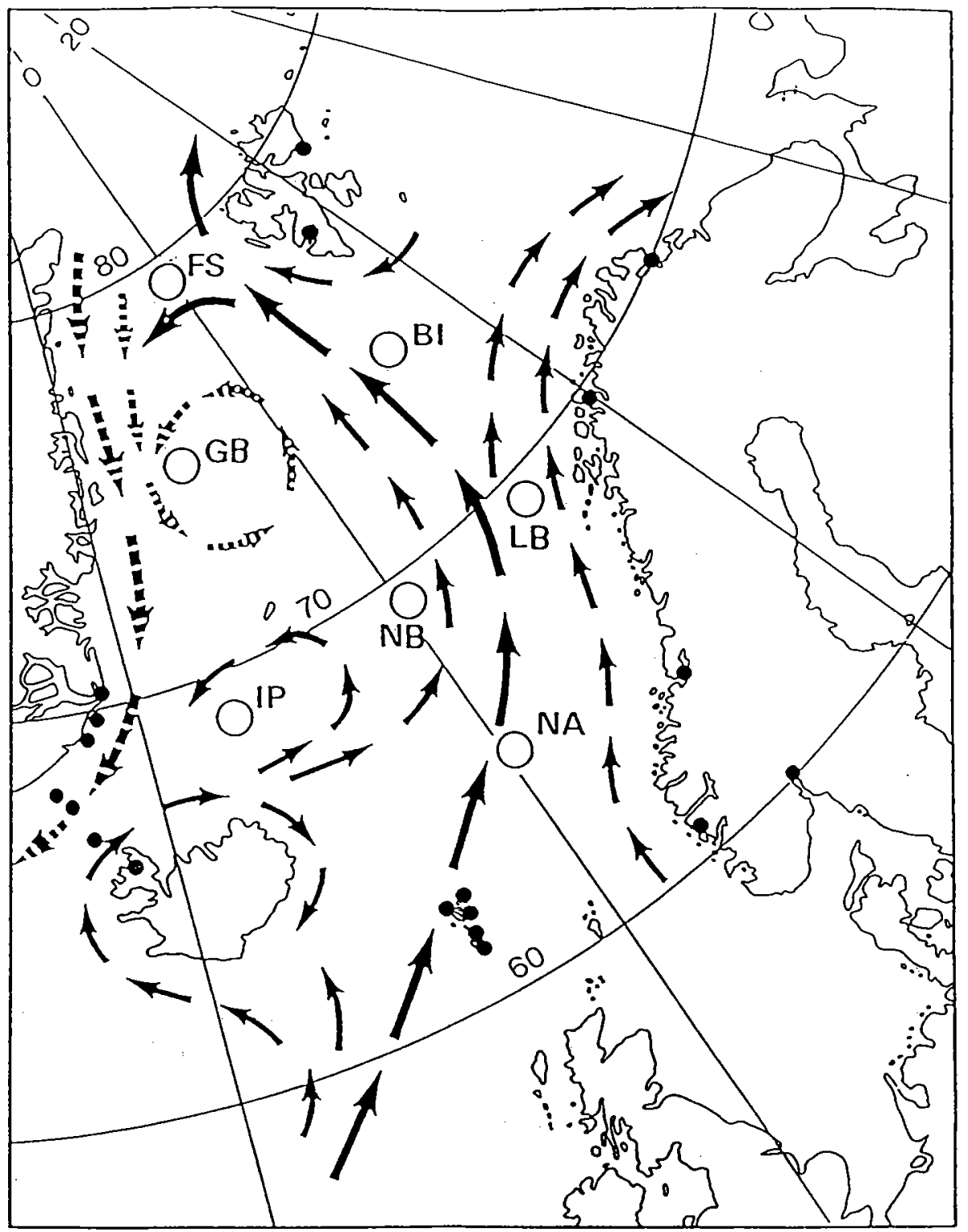

Figure 3.1: Map of Nordic Seas region, showing locations of sediment trap stations used for cyst studies. NA = Aegir Ridge station, $\mathrm{LB}=$ Lofoten Basin station, $\mathrm{BI}=\mathrm{Bear}$ Island station, FS = Fram Strait station, and GB = Greenland Basin station. Smaller, unlabeled, filled circles show locations of coastal sediment samples previously studied for dinoflagellate cysts. Solid arrows represent the Norwegian Atlantic Current, and hatched arrows represent the East Greenland Current. Schematic surface currents after Kellog, 1973. 
Table 3.1: Station data for 7 sediment trap deployments in the Nordic Seas. Asterisk (*) indicates stations not included in this discussion. Surface water temperatures from Dietrich, 1969 and Johannessen, 1986.

\begin{tabular}{|c|c|c|c|c|c|c|c|}
\hline Station & Code & $\begin{array}{c}\text { Latitude } \\
\text { Longitude } \\
\text { (deg. min.) }\end{array}$ & $\begin{array}{c}\text { Trap } \\
\text { Depth } \\
(\mathbf{m})\end{array}$ & $\begin{array}{l}\text { Water } \\
\text { Depth } \\
(\mathrm{m})\end{array}$ & $\begin{array}{l}\text { Trap Open- } \\
\text { Trap Closed } \\
\text { (mo/day } / \text { yr) }\end{array}$ & $\begin{array}{l}\text { No. cups/ } \\
\text { Duration } \\
\text { (days:hrs) }\end{array}$ & $\begin{array}{c}\text { Average } \\
\text { Annual } \\
T\left({ }^{\circ} \mathbf{C}\right)\end{array}$ \\
\hline Aegir Ridge & (NA) & $\begin{array}{l}65^{\circ} 31^{\prime} \mathrm{N} \\
00^{\circ} 64^{\prime} \mathrm{E}\end{array}$ & 2630 & 3058 & $\begin{array}{l}8 / 21 / 85 \\
6 / 16 / 86\end{array}$ & $\begin{array}{l}13 / \\
23: 0\end{array}$ & $6-11$ \\
\hline Lofoten Basin & (LB) & $\begin{array}{l}69^{\circ} 30^{\prime} \mathrm{N} \\
10^{\circ} 00^{\prime} \mathrm{E}\end{array}$ & 2761 & 3161 & $\begin{array}{l}8 / 15 / 83 \\
8 / 01 / 84\end{array}$ & $\begin{array}{l}12 / \\
30: 0\end{array}$ & $6-9$ \\
\hline Bear Island & (BI) & $\begin{array}{l}75^{\circ} 52^{\prime} \mathrm{N} \\
11^{\circ} 28^{\prime} \mathrm{E}\end{array}$ & 1700 & 2123 & $\begin{array}{l}8 / 13 / 84 \\
8 / 10 / 85\end{array}$ & $\begin{array}{l}12 / \\
30: 4\end{array}$ & $4-6$ \\
\hline Fram Strait & $(\mathbf{F S})$ & $\begin{array}{l}78^{\circ} 51^{\prime} \mathrm{N} \\
01^{\circ} 22^{\prime} \mathrm{E}\end{array}$ & 2146 & 2527 & $\begin{array}{l}8 / 20 / 84 \\
8 / 15 / 85\end{array}$ & $\begin{array}{l}13 / \\
27: 5\end{array}$ & $0-3$ \\
\hline Greenland Basin & (GB) & $\begin{array}{r}74^{\circ} 35^{\prime} \mathrm{N} \\
06^{\circ} 43^{\prime} \mathrm{W}\end{array}$ & 2823 & 3445 & $\begin{array}{l}8 / 04 / 85 \\
8 / 03 / 86\end{array}$ & $\begin{array}{l}13 / \\
28: 0\end{array}$ & $-1-4$ \\
\hline *Norwegian Basin & (NB) & $\begin{array}{l}70^{\circ} 00^{\prime} \mathrm{N} \\
01^{\circ} 58^{\prime} \mathrm{W}\end{array}$ & 2749 & 3296 & $\begin{array}{l}8 / 25 / 85 \\
3 / 24 / 86\end{array}$ & $\begin{array}{c}17 / \\
12: 0\end{array}$ & $5-9$ \\
\hline -Iceland Plateau & (IP) & $\begin{array}{r}68^{\circ} 01^{\prime} \mathrm{N} \\
12^{\circ} 40^{\prime} \mathrm{W}\end{array}$ & 1457 & 1880 & $\begin{array}{c}10 / 22 / 88 \\
10 / 08 / 89\end{array}$ & $\begin{array}{l}13 / \\
27: 0\end{array}$ & $4-6$ \\
\hline
\end{tabular}

\section{Materials and Methods}

\section{Samples}

Station data for the 63 time-series sediment trap samples used in this investigation are shown in Table 3.1. Figure 3.1 shows the locations of the sediment trap stations, and identifies coastal sites previously studied for dinoflagellate cysts. Mark V sediment traps with an aperture of $1.17 \mathrm{~m}^{2}$ were used at stations $\mathrm{LB}, \mathrm{BI}$, and GB, and Mark VI sediment traps with an aperture of $0.5 \mathrm{~m}^{2}$ were used at stations NA, and FS. The design and construction of both these traps are described by Honjo and Doherty (1988). Each sample represents approximately one month of sedimentation, at 400-600 meters above the ocean bottom, in 2,000 to 3,500 meter water depth. Each deployment collected sediment for approximately one year. Total sediment flux data, giving breakdowns of the various biogenic and lithogenic constituents for these samples were reported by Honjo et al. (1987).

\section{Sample Preparation and Examination}

After thoroughly shaking to homogenize the sample, an aliquot portion was wet sieved with a mesh size of $25 \mu \mathrm{m}$, routinely used for concentrating cysts. In cases where foraminifera were abundant, a $1 \mathrm{~mm}$ sieve was also used, to remove the coarser fraction prior to slide preparation. The size fraction $25 \mu \mathrm{m}-1 \mathrm{~mm}$ was then mounted in permanent microscope slides using glycerine jelly, and remains of dinoflagellates (mainly cysts) were examined in the light microscope, both quantitatively (\# cysts $/ \mathrm{m}^{2} /$ day) and qualitatively (cyst assemblages). 


\section{Taxonomic Notes}

The cyst category, "undifferentiated spherical, brown protoperidinioid cysts", includes several types which are extremely difficult to identify to species level without the presence of an excystment opening (archeopyle), which is visible in only a minority of specimens. They are therefore grouped together, here, as "spherical brown protoperidinioid cysts". The majority of these which could be identified were assigned to Protoperidinium conicoides, but $P$. avellana and $P$. denticulatum also were seen, and at least one undescribed cyst type of consistently larger size (roughly $65 \mu \mathrm{m}$ ). In the discussion below, "calcareous cysts" refers to a spherical cyst type with an angular archeopyle (c.f. Thoracosphaera albatrosiana) previously seen by Dale in the central oceanic gyres of the Atlantic and Pacific oceans (see chapter 1, this volume). However, since this taxonomic assignment is in need of revision, these were simply called "calcareous cysts" in this study. The name "Multispinula minuta" is retained here for the cyst species originally called "Multispinula? minuta" by Harland and Reid in Harland et al. (1980), pending formal taxonomic revision. The main cyst types documented in this study are illustrated in Plate 3.1.

\section{Treatment of Cyst Data}

Results were normalized to fluxes of cysts per day, calculated according to the following formula:

$\frac{(\text { total number cysts }) \cdot(\text { aliquot portion of sample })}{(\text { number days in sampling interval }) /(\text { area of trap opening })}$

Percentage abundances for each cyst type were figured on the basis of total cyst fluxes, and these are shown in Table 3.2 .

Total cyst and total sediment fluxes (calculated earlier by Honjo et al., 1987), together with cyst data and sample information for each station, are shown in Tables 3.3-3.7. Because in most cases fewer than 100 cysts were seen for any one sampling interval, percentage abundances are not given by sampling interval. However, seasonal flux distributions at each station for all cyst types comprising $5 \%$ or more of the total assemblage are shown in Figures 3.2-3.6.

The relationships between cyst fluxes at all five stations were compared statistically using the MVSP-PLUS (Multivariate Statistical Package) program, written by Dr. Warren L. Kovach, University College of Wales, Aberystwyth. A similarity matrix was constructed using the Pearson Product Moment correlation coefficient for input into the Cluster Analysis routine of MVSP. A hierarchical agglomerative cluster analysis was then performed, using the unweighted pair group method. The raw data were ordered schematically using the SORTDATA routine of MVSP. The cluster diagrams were plotted using the PLOTGRAM program, written by Chris Meachem, University of California, Berkeley. 
Table 3.2: Percentage abundances and total number of cysts recorded for 5 sediment trap stations studied for dinoflagellate cysts. Percentages are based on cyst fluxes (\# cysts $/ \mathrm{m}^{2} /$ day). Abbreviations are as follows: Btep = Bitectatodinium tepikiense; Calc $=$ spherical calcareous cysts; Ipal = Impagidinium pallidum; Isph = Impagidinium sphaericum; Mmin = Multispinula minuta $;$ Nlab = Nematosphaeropsis labyrinthus $;$ Ocen $=$ Operculodinium centrocarpum $;$ Pfae $=$ Peridinium faeroense $;$ Psch $=$ Polykrikos schwartzii; Pame = Protoperidinium americanum; Pcon = Protoperidinium conicum; Pleo = Protoperidinium leonis $;$ Ppen = Protoperidinium pentagonum; Stro = Scrippsiella trochoidea; SPPr = undifferentiated, spherical brown protoperidinioid cysts; Sbul = Spiniferites bulloideus $;$ Selo = Spiniferites elongatus $;$ Sram = Spiniferites ramosus $;$ Fm5 = Form 5; Fm14 = Form 14; Fm17 = Form 17; Fm19 = Form 19. Total Seen = total number of cysts documented at the station. $P$ indicates abundance less than $1 \%$.

\begin{tabular}{|lrcccc|}
\hline \hline & $\begin{array}{c}\text { Aegir } \\
\text { Ridge } \\
\text { (NA) }\end{array}$ & $\begin{array}{c}\text { Lofoten } \\
\text { Basin } \\
\text { (LB) }\end{array}$ & $\begin{array}{c}\text { Bear } \\
\text { Island } \\
\text { (BI) }\end{array}$ & $\begin{array}{c}\text { Fram } \\
\text { Strait } \\
\text { (FS) }\end{array}$ & $\begin{array}{c}\text { Greenland } \\
\text { Basin } \\
\text { (GB) }\end{array}$ \\
\hline Btep & & & & & \\
Calc & 1 & P & 0 & 0 & 0 \\
Ipal & 12 & 10 & 2 & 2 & 0 \\
Isph & 4 & 2 & 9 & 33 & 47 \\
Mmin & 0 & P & 0 & P & 0 \\
Nlab & 1 & 2 & 10 & 20 & 12 \\
Ocen & 6 & 4 & 13 & 3 & 3 \\
Pfae & 1 & 13 & 15 & 3 & 2 \\
Psch & 11 & 6 & 25 & 5 & 4 \\
Pame & 2 & 2 & P & 0 & 0 \\
Pcon & 2 & 2 & 1 & 0 & 0 \\
Pleo & 3 & 2 & P & 0 & 0 \\
Ppen & P & 0 & 0 & 0 & 0 \\
Stro & 0 & 2 & 0 & 0 & 0 \\
SPPr & 1 & 3 & P & 1 & 0 \\
Sbul & 46 & 50 & 18 & 30 & 32 \\
Selo & 2 & P & P & 0 & 0 \\
Sram & 4 & 1 & 1 & 0 & 0 \\
Fm5 & P & P & P & 0 & 0 \\
Fm14 & 4 & 1 & 0 & 0 & 0 \\
Fm17 & 0 & 0 & 4 & 2 & 0 \\
Fm19 & 0 & 0 & 0 & P & 0 \\
Total Seen: & $\mathbf{3}$ & 0 & 0 & P & 0 \\
& & & & & \\
\hline \hline
\end{tabular}



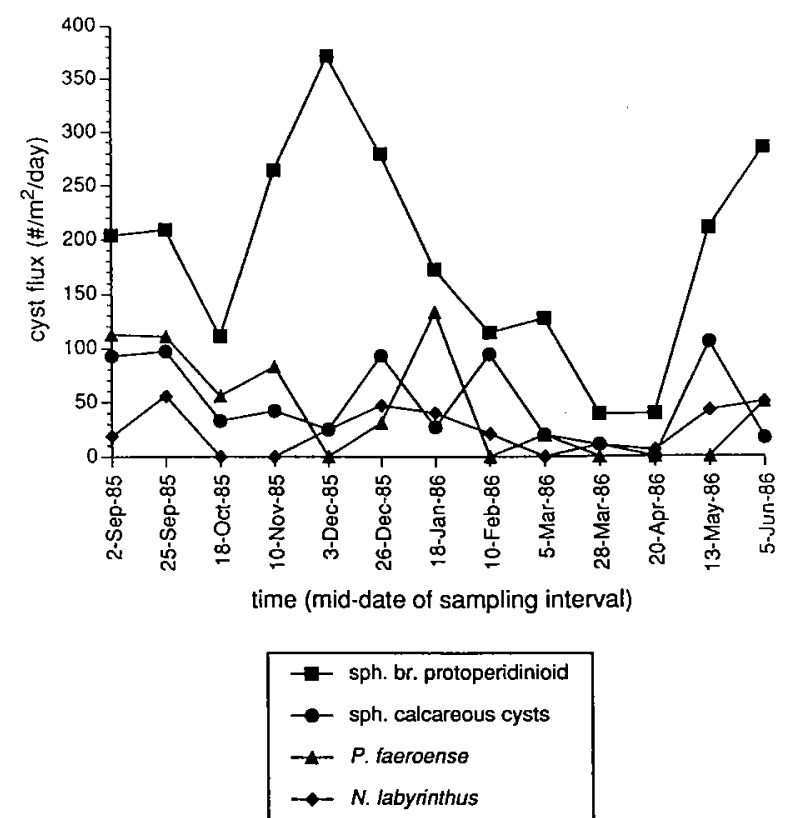

Figure 3.2: Cyst distribution for species representing 5\% or more of the total assemblage at the Aegir Ridge (NA) station.

Table 3.3: Sampling intervals, total number of cysts seen, total cyst and sediment fluxes for the Aegir Ridge (NA) deployment (1985-1986).

\begin{tabular}{|c|c|c|c|c|c|c|c|}
\hline $\begin{array}{l}\text { Sample } \\
\text { I.D. }\end{array}$ & $\begin{array}{c}\text { Trap } \\
\text { Opening } \\
\text { Date } \\
\text { (date mo. yr.) }\end{array}$ & $\begin{array}{c}\text { Trap } \\
\text { Closing } \\
\text { Date } \\
\text { (date mo. yr.) }\end{array}$ & $\begin{array}{l}\text { No. } \\
\text { Cysts } \\
\text { Seen }\end{array}$ & $\begin{array}{c}\text { Total } \\
\text { Cyst } \\
\text { Flux } \\
\left.\text { (\# } / \mathbf{m}^{2} / \text { day }\right)\end{array}$ & $\begin{array}{l}\text { Percent } \\
\text { Total } \\
\text { Cyst } \\
\text { Flux }\end{array}$ & $\begin{array}{c}\text { Total } \\
\text { Sediment } \\
\text { Flux } \\
\left(\mathbf{m g} / \mathbf{m}^{2} / \text { day }\right)\end{array}$ & $\begin{array}{c}\text { Percent } \\
\text { Total } \\
\text { Sediment } \\
\text { Flux }\end{array}$ \\
\hline NA1-1 & 21 Aug. 85 & 13 Sep. 85 & 38 & 705 & 13 & 54 & 9 \\
\hline NA1-2 & 13 Sep. 85 & 06 Oct. 85 & 48 & 668 & 13 & 69 & 16 \\
\hline NA1-3 & 06 Oct. 85 & 29 Oct. 85 & 26 & 289 & 5 & 69 & 18 \\
\hline NA1-4 & 29 Oct. 85 & 21 Nov. 85 & 33 & 459 & 9 & 68 & 7 \\
\hline NA1-5 & 21 Nov. 85 & 14 Dec. 85 & 22 & 544 & 10 & 92 & 4 \\
\hline NA1- 6 & 14 Dec. 85 & 06 Jan. 86 & 43 & 665 & 13 & 55 & 3 \\
\hline NA1-7 & $06 \mathrm{Jan} .86$ & 29 Jan. 86 & 38 & 504 & 10 & 45 & 2 \\
\hline NA1-8 & 29 Jan. 86 & 21 Feb. 86 & 27 & 282 & 5 & 29 & 3 \\
\hline NA1-9 & $21 \mathrm{Feb} .86$ & 16 Mar. 86 & 33 & 230 & 4 & 22 & 22 \\
\hline NA1-10 & 16 Mar. 86 & 08 Apr. 86 & 12 & 67 & 1 & 7 & 4 \\
\hline NA1-11 & $08 \mathrm{Apr} .86$ & 01 May 86 & 10 & 56 & 1 & 6 & 2 \\
\hline NA1-12 & 01 May 86 & 24 May 86 & 18 & 376 & 7 & 43 & 7 \\
\hline NA1-13 & 24 May 86 & 16 Jun. 86 & 27 & 451 & 9 & 59 & 3 \\
\hline \multicolumn{8}{|c|}{$\begin{array}{l}\text { Average Cyst Flux: } 407 / \mathrm{m}^{2} / \text { day } \\
\text { Number of Cyst Species Documented: } 16\end{array}$} \\
\hline
\end{tabular}




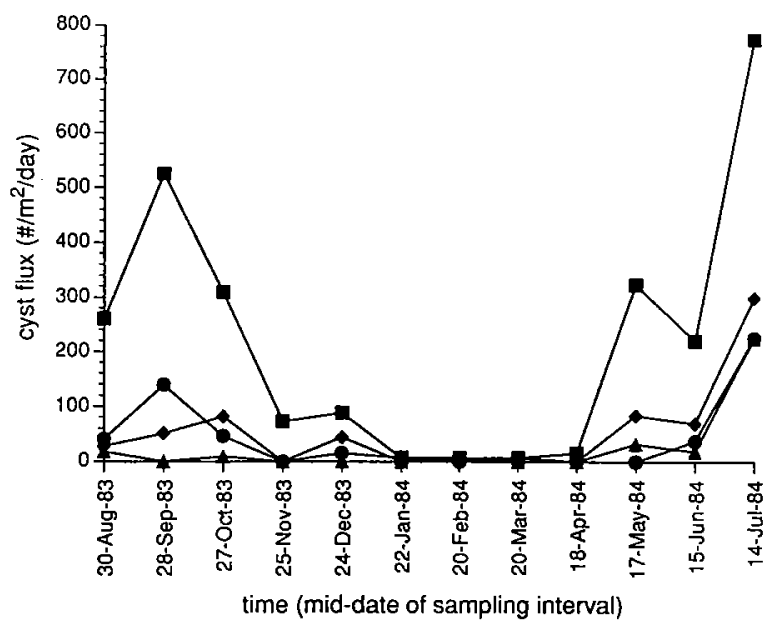

$$
\begin{aligned}
& - \text { sph. br. protoperidinioid } \\
& - \text { - sph. calcareous cysis } \\
& \rightarrow-\text { P. faeroense } \\
& \rightarrow \text { O. centrocamum }
\end{aligned}
$$

Figure 3.3: Cyst distribution for species representing 5\% or more of the total assemblage

\begin{tabular}{|c|c|c|c|c|c|c|c|}
\hline $\begin{array}{c}\text { Sample } \\
\text { I.D. }\end{array}$ & $\begin{array}{c}\text { Trap } \\
\text { Opening } \\
\text { Date } \\
\text { (date mo. yr.) }\end{array}$ & $\begin{array}{c}\text { Trap } \\
\text { Closing } \\
\text { Date } \\
\text { (date mo. yr.) }\end{array}$ & $\begin{array}{l}\text { No. } \\
\text { Cysts } \\
\text { Seen }\end{array}$ & $\begin{array}{c}\text { Total } \\
\text { Cyst } \\
\text { Flux } \\
\left.\text { (\#/m } / \mathrm{m}^{2} / \text { day }\right)\end{array}$ & $\begin{array}{c}\text { Percent } \\
\text { Total } \\
\text { Cyst } \\
\text { Flux }\end{array}$ & $\begin{array}{c}\text { Total } \\
\text { Sediment } \\
\text { Flux } \\
\left(\mathbf{m g} / \mathbf{m}^{2} / \text { day }\right)\end{array}$ & $\begin{array}{c}\text { Percent } \\
\text { Total } \\
\text { Sediment } \\
\text { Flux }\end{array}$ \\
\hline LB1-1 & 15 Aug. 83 & $13 \mathrm{Sep} .83$ & 99 & 410 & 7 & 102 & 14 \\
\hline LB 1-2 & 13 Sep. 83 & 12 Oct. 83 & 66 & 955 & 17 & 162 & 22 \\
\hline LB1-3 & 12 Oct. 83 & 11 Nov. 83 & 65 & 593 & 10 & 141 & 19 \\
\hline LB1-4 & 11 Nov. 83 & 10 Dec. 83 & 13 & 119 & 2 & 44 & 6 \\
\hline LB1-5 & 10 Dec. 83 & 08 Jan. 84 & 27 & 197 & 3 & 19 & 3 \\
\hline LB1- 6 & $08 \mathrm{Jan} .84$ & $07 \mathrm{Feb} .84$ & 2 & 15 & $<1$ & 6 & 1 \\
\hline LB1-7 & 07 Feb. 84 & 07 Mar. 84 & 4 & 29 & 1 & 8 & 1 \\
\hline LB1-8 & 07 Mar. 84 & $05 \mathrm{Apr} .85$ & 5 & 37 & 1 & 5 & I \\
\hline LB1-9 & $05 \mathrm{Apr} .84$ & 05 May 84 & 2 & 15 & $<1$ & 4 & 1 \\
\hline LB1-10 & 05 May 84 & 03 Jun. 84 & 118 & 538 & 9 & 57 & 8 \\
\hline LB1-11 & 03 Jun. 84 & $02 \mathrm{Jul} .84$ & 103 & 476 & 8 & 73 & 10 \\
\hline LB1-12 & $02 \mathrm{Jul} .84$ & 01 Aug. 84 & 97 & 2358 & 41 & 128 & 18 \\
\hline \multicolumn{8}{|c|}{ Recycled Pre-Quaternary Cyst Flux: } \\
\hline $\begin{array}{l}\text { LB1-11 } \\
\text { LB1-12 }\end{array}$ & $\begin{array}{l}\text { 03 Jun. } 84 \\
02 \text { Jul. } 84\end{array}$ & $\begin{array}{c}02 \text { Jul. } 84 \\
01 \text { Aug. } 84\end{array}$ & $\begin{array}{r}8 \\
208\end{array}$ & $\begin{array}{r}37 \\
5172\end{array}$ & $\begin{array}{r}1 \\
99\end{array}$ & $\begin{array}{r}73 \\
128\end{array}$ & $\begin{array}{l}10 \\
18\end{array}$ \\
\hline \multicolumn{8}{|c|}{$\begin{array}{l}\text { Average Cyst Flux (Recent): } 479 / \mathrm{m}^{2} / \text { day } \\
\text { Total Recycled Pre-Quaternary Cyst Fluxs } 6,209 / \mathrm{m}^{2} / \mathrm{yr} \\
\text { Number of Cyst Species Documented (Recent): } 16\end{array}$} \\
\hline
\end{tabular}
at the Lofoten Basin (LB) station.

Table 3.4: Sampling intervals, total number of cysts seen, total cyst and sediment fluxes for the Lofoten Basin (LB) deployment (1983-1984). 

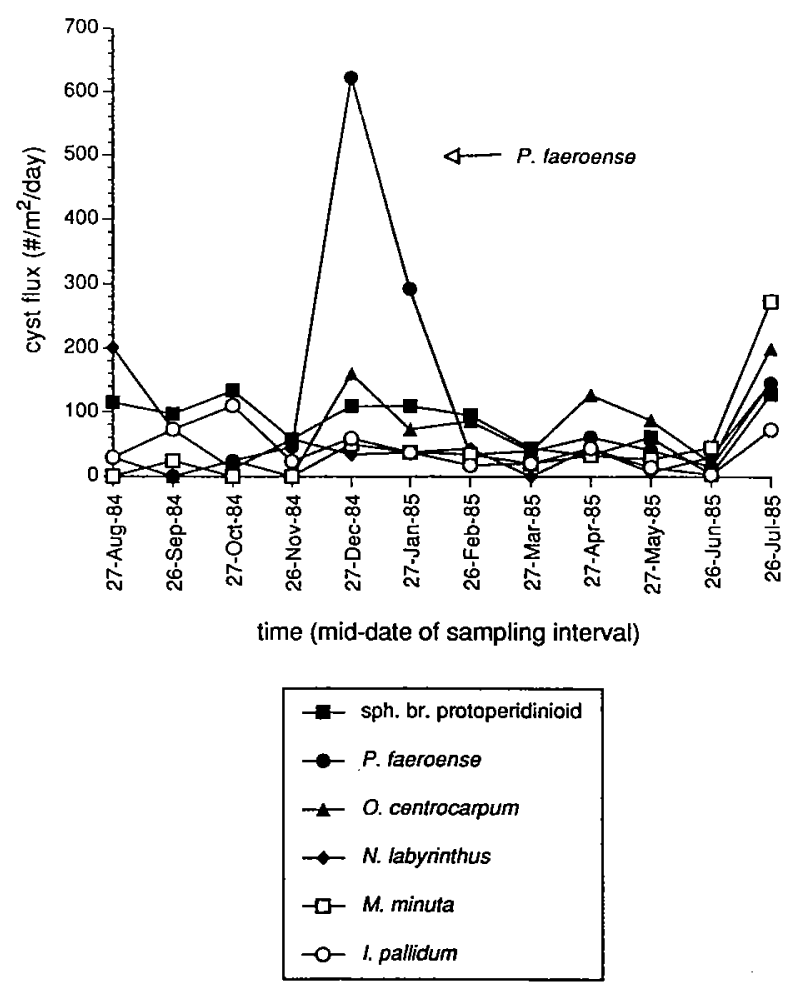

Figure 3.4: Cyst distribution for species representing 5\% or more of the total assemblage at the Bear Island (BI) station. Note the pronounced spike of $P$. faeroense cysts during the December 11, 1984 - January 12, 1985, and January 12 to February 11, 1985, sampling intervals.

Table 3.5: Sampling intervals, total number of cysts seen, total cyst and sediment fluxes for the Bear Island (BI) deployment (1984-1985).

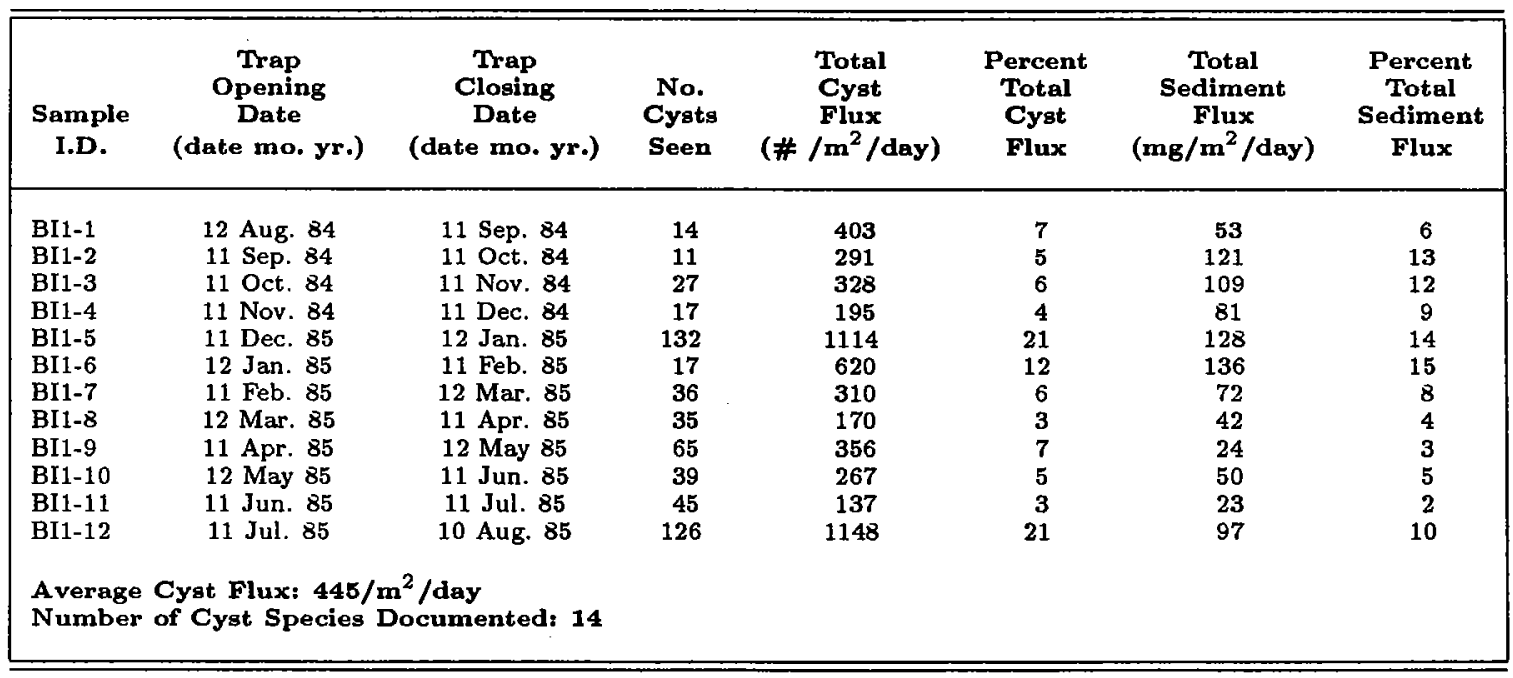



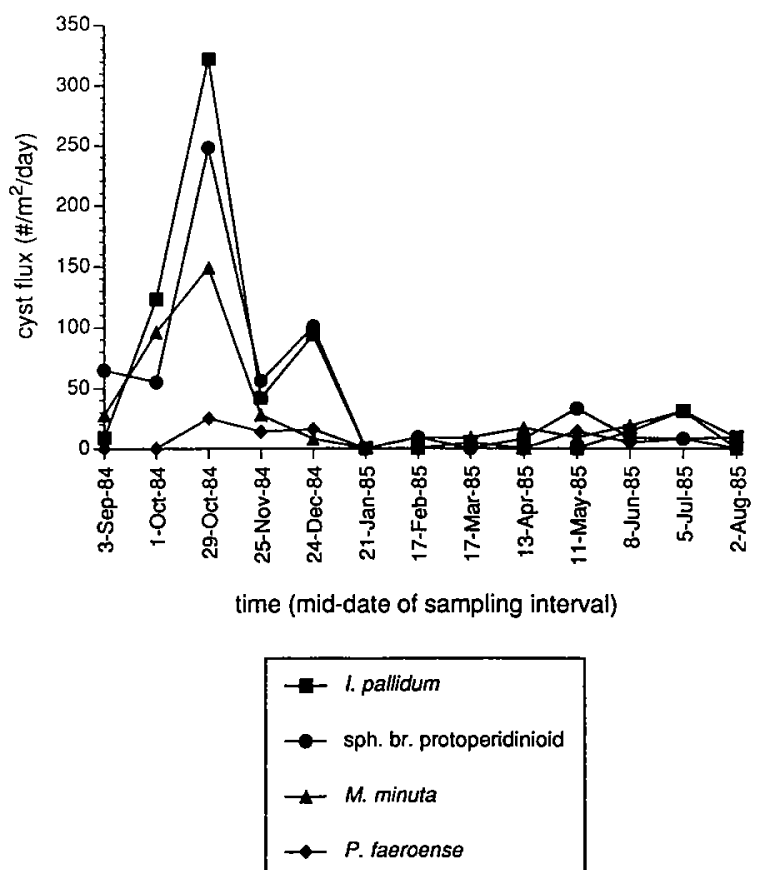

Figure 3.5: Cyst distribution for species representing 5\% or more of the total assemblage at the Fram Strait (FS) station.

Table 3.6: Sampling intervals, total number of cysts seen, total cyst and sediment fluxes for the Fram Strait (FS) deployment (1984-1985).

\begin{tabular}{|c|c|c|c|c|c|c|c|}
\hline $\begin{array}{l}\text { Sample } \\
\text { I.D. }\end{array}$ & $\begin{array}{c}\text { Trap } \\
\text { Opening } \\
\text { Date } \\
\text { (date mo. yr.) }\end{array}$ & $\begin{array}{c}\text { Trap } \\
\text { Closing } \\
\text { Date } \\
\text { (date mo. yr.) }\end{array}$ & $\begin{array}{l}\text { No. } \\
\text { Cysts } \\
\text { Seen }\end{array}$ & $\begin{array}{l}\text { Total } \\
\text { Cyst } \\
\text { Flux } \\
\left.\text { (\# } / \mathbf{m}^{2} / \text { day }\right)\end{array}$ & $\begin{array}{c}\text { Percent } \\
\text { Total } \\
\text { Cyst } \\
\text { Flux }\end{array}$ & $\begin{array}{c}\text { Total } \\
\text { Sediment } \\
\text { Flux } \\
\left(\mathrm{mg} / \mathrm{m}^{2} / \text { day }\right)\end{array}$ & $\begin{array}{c}\text { Percent } \\
\text { Total } \\
\text { Sediment } \\
\text { Flux }\end{array}$ \\
\hline FS1-1 & 20 Aug. 84 & $17 \mathrm{Sep} .84$ & 13 & 121 & 6 & 22 & 9 \\
\hline FS1-2 & 17 Sep. 84 & 15 Oct. 84 & 23 & 315 & 16 & 40 & 16 \\
\hline FS1-3 & 15 Oct. 84 & 11 Nov. 84 & 32 & 794 & 41 & 45 & 18 \\
\hline FS1-4 & 11 Nov. 84 & 09 Dec. 84 & 12 & 168 & 9 & 18 & 7 \\
\hline FS1-5 & 09 Dec. 85 & 07 Jan. 85 & 30 & 233 & 12 & 10 & 4 \\
\hline FS1-6 & $07 \mathrm{Jan} .85$ & 03 Feb. 85 & 0 & 0 & 0 & 7 & 3 \\
\hline FS1-7 & 03 Feb. 85 & $03 \mathrm{Mar} .85$ & 6 & 28 & 1 & 5 & 2 \\
\hline FS1-8 & 03 Mar. 85 & 30 Mar. 85 & 6 & 28 & 1 & 7 & 3 \\
\hline FS1-9 & 30 Mar. 85 & 27 Apr. 85 & 3 & 25 & 1 & 56 & 22 \\
\hline FS1-10 & 27 Аpr. 85 & 25 May 85 & 13 & 61 & 3 & 10 & 4 \\
\hline FS1-11 & 25 May 85 & 21 Jun. 85 & 12 & 56 & 3 & 6 & 2 \\
\hline FS1-12 & 21 Jun. 85 & 19 Jul. 85 & 14 & 109 & 6 & 17 & 7 \\
\hline FS1-12 & 19 Jul. 85 & 15 Aug. 85 & 6 & 28 & 1 & 7 & 3 \\
\hline \multicolumn{8}{|c|}{$\begin{array}{l}\text { Average Cyst Flux: } 151 / \mathrm{m}^{2} / \text { day } \\
\text { Number of Cyst Species Documented: } 10\end{array}$} \\
\hline
\end{tabular}



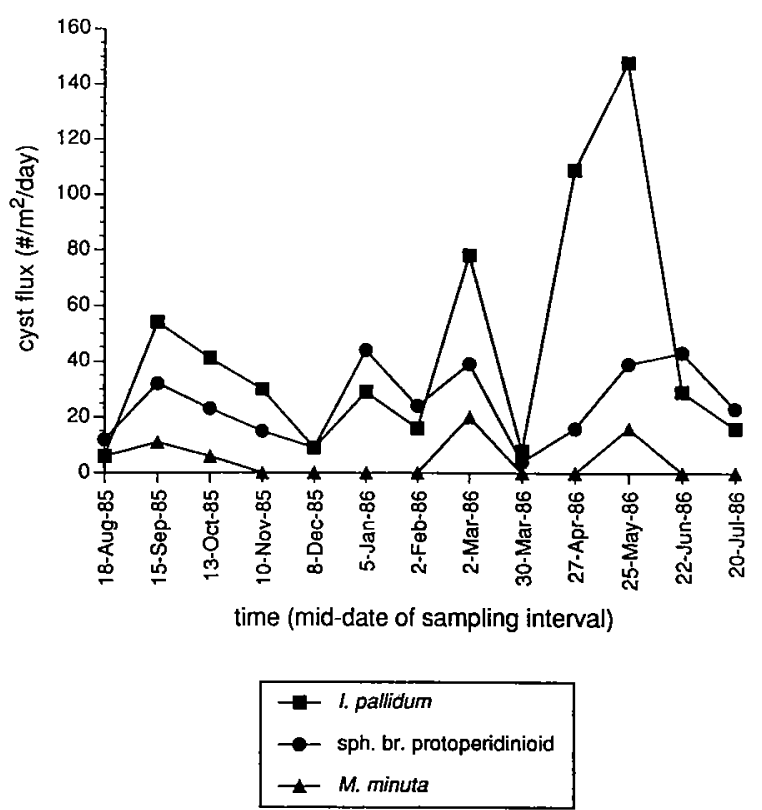

Figure 3.6: Cyst distribution for species representing 5\% or more of the total assemblage at the Greenland Basin (GB) station.

Table 3.7: Sampling intervals, total number of cysts seen, total cyst and sediment fluxes for the Greenland Basin (GB) deployment (1985-1986).

\begin{tabular}{|c|c|c|c|c|c|c|c|}
\hline $\begin{array}{c}\text { Sample } \\
\text { I.D. }\end{array}$ & $\begin{array}{c}\text { Trap } \\
\text { Opening } \\
\text { Date } \\
\text { (date mo. yr.) }\end{array}$ & $\begin{array}{c}\text { Trap } \\
\text { Closing } \\
\text { Date } \\
\text { (date mo. yr.) }\end{array}$ & $\begin{array}{l}\text { No. } \\
\text { Cysts } \\
\text { Seen }\end{array}$ & $\begin{array}{c}\text { Total } \\
\text { Cyst } \\
\text { Flux } \\
\left.\text { (\# } / \mathbf{m}^{2} / \text { day }\right)\end{array}$ & $\begin{array}{c}\text { Percent } \\
\text { Total } \\
\text { Cyst } \\
\text { Flux }\end{array}$ & $\begin{array}{c}\text { Total } \\
\text { Sediment } \\
\text { Flux } \\
\left(\mathbf{m g} / \mathbf{m}^{2} / \text { day }\right)\end{array}$ & $\begin{array}{c}\text { Percent } \\
\text { Total } \\
\text { Sediment } \\
\text { Flux }\end{array}$ \\
\hline GB23-1 & 04 Aug. 85 & 01 Sep. 85 & 4 & 23 & 2 & 19 & $\mathbf{5}$ \\
\hline GB23-2 & 01 Sep. 85 & 29 Sep. 85 & 10 & 107 & 11 & 30 & 8 \\
\hline GB23-3 & 29 Sep. 85 & 27 Oct. 85 & 12 & 70 & 7 & 29 & 8 \\
\hline GB23-4 & 27 Oct. 85 & 24 Nov. 85 & 3 & 44 & 4 & 32 & 9 \\
\hline GB23-5 & 24 Nov. 85 & 22 Dec. 85 & 4 & 18 & 2 & 18 & 5 \\
\hline GB23-6 & 22 Dec. 85 & $19 \mathrm{Jan} .86$ & $\mathbf{5}$ & 73 & 7 & 28 & 8 \\
\hline GB23-7 & 19 Jan. 86 & $16 \mathrm{Feb} .86$ & 5 & 41 & 4 & 29 & 8 \\
\hline GB23-8 & 16 Feb. 86 & 16 Mar. 86 & 7 & 137 & 14 & 23 & 6 \\
\hline GB23-9 & 16 Mar. 86 & 13 Apr. 86 & 3 & 12 & 1 & 18 & 5 \\
\hline GB23-10 & $13 \mathrm{Apr} .86$ & 11 May 86 & 16 & 125 & 13 & 27 & 7 \\
\hline GB23-11 & 11 May 86 & 08 Jun. 86 & 27 & 211 & 21 & 24 & 7 \\
\hline GB23-12 & 08 Jun. 86 & $06 \mathrm{Jul} .86$ & 5 & 72 & 7 & 26 & 7 \\
\hline GB23-13 & 06 Jul. 86 & 03 Aug. 86 & 13 & 51 & 5 & 61 & 17 \\
\hline
\end{tabular}




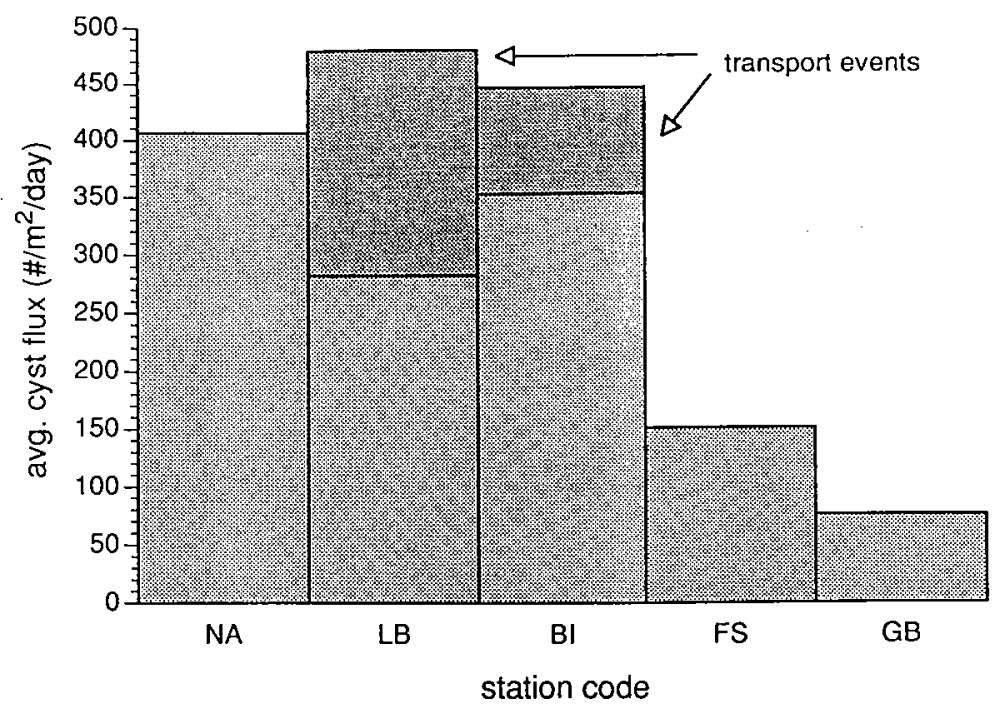

Figure 3.7: Average daily cyst fluxes at five stations compared. The uppermost section of the Lofoten Basin (LB) represents $41 \%$ of the total cyst flux, deposited during the July 2 - August 1, 1984, sampling interval, and the uppermost section of the Bear Island (BI) station represents $33 \%$ of the total cyst flux, deposited during the December 11, 1984 February 11, 1985, sampling intervals; both reflect sediment transport events described in the text.

\section{Results and Discussion}

Dinoflagellate cysts were recorded at all stations. A total of 25 cyst species and 6 main acritarch types (not included here) were documented. The most striking feature of the Nordic Seas assemblages was the strong dominance by organic-walled forms. This contrasts sharply with previous findings by Dale (1986; Chapters 1 and 2, this volume) for the Equatorial Atlantic and Central Pacific Oceans and the Panama Basin, where calcareous cysts were found to dominate the dinoflagellate flux. Only 2 of the 25 cyst types recorded were calcareous; the other 23 were organic-walled forms (Table 3.2). Dinoflagellate thecae were seen only very occasionally (predominantly species of the genus Dinophysis), and these were considered outside the scope of this study.

\section{Cyst Fluxes}

Total cyst fluxes for all 5 stations are shown in Figure 3.7, and total cyst and sediment fluxes for each station individually are shown in Figures 3.8-3.12. Total cyst fluxes were distinctly higher for the stations influenced by the warmer, Norwegian Atlantic Current than for stations influenced by the colder, East Greenland Current (407, 479, and $445 \mathrm{cysts} / \mathrm{m}^{2} / \mathrm{day}$ ), respectively, for stations Aegir Ridge (NA), Lofoten Basin (LB) and Bear Island (BI), as compared with 151 and $76 \mathrm{cysts} / \mathrm{m}^{2} /$ day, respectively, for stations Fram Strait (FS) and Greenland Basin (GB); Figure 3.7). The ratios of total cyst fluxes 


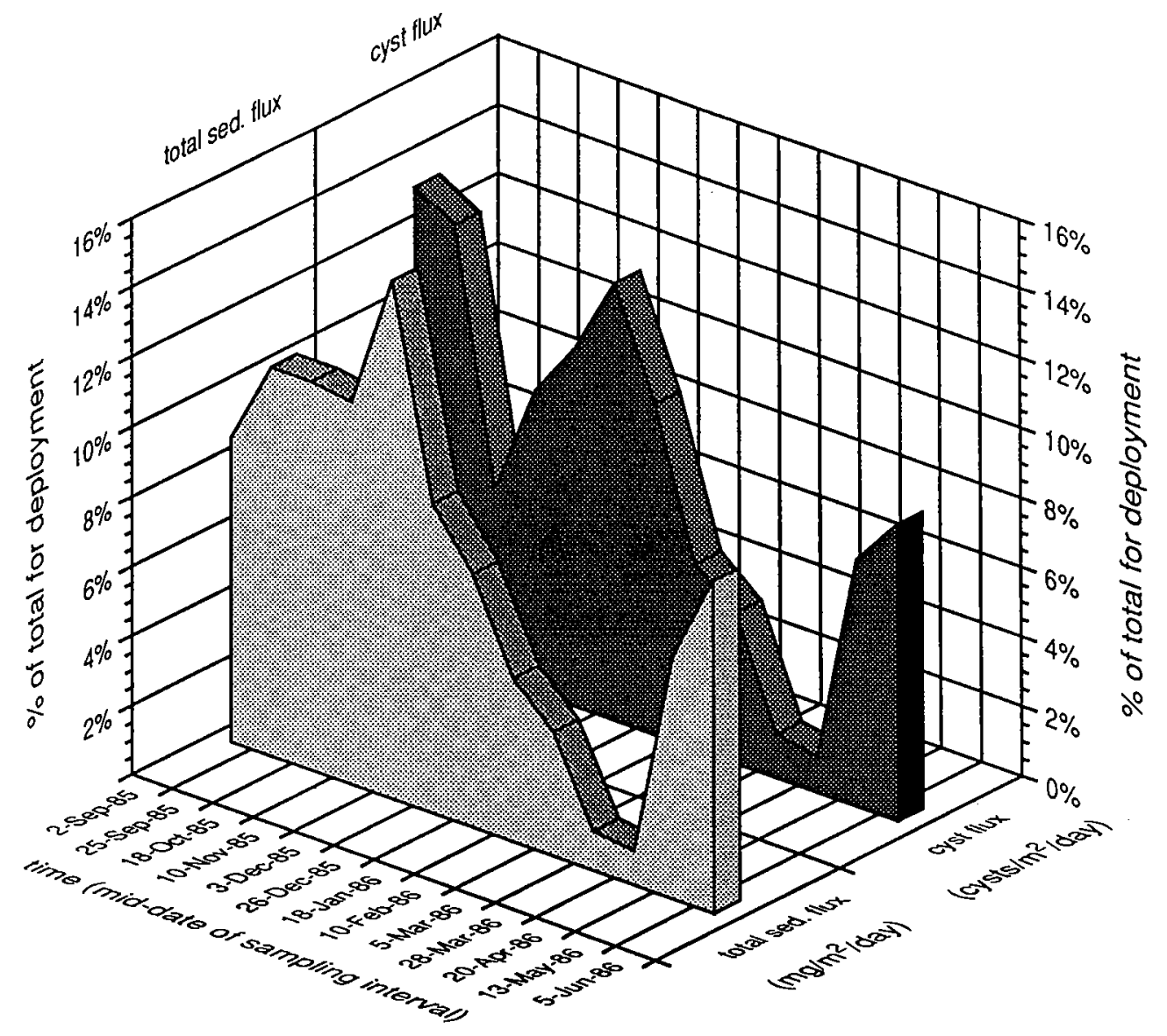

cyst flux

total sed. flux

Figure 3.8: Percentage cyst and total sediment fluxes at Aegir Ridge (NA). Correlation coefficient $(r)$ between total sediment and cyst fluxes $=0.75$. For flux values, see Table 3.3. 


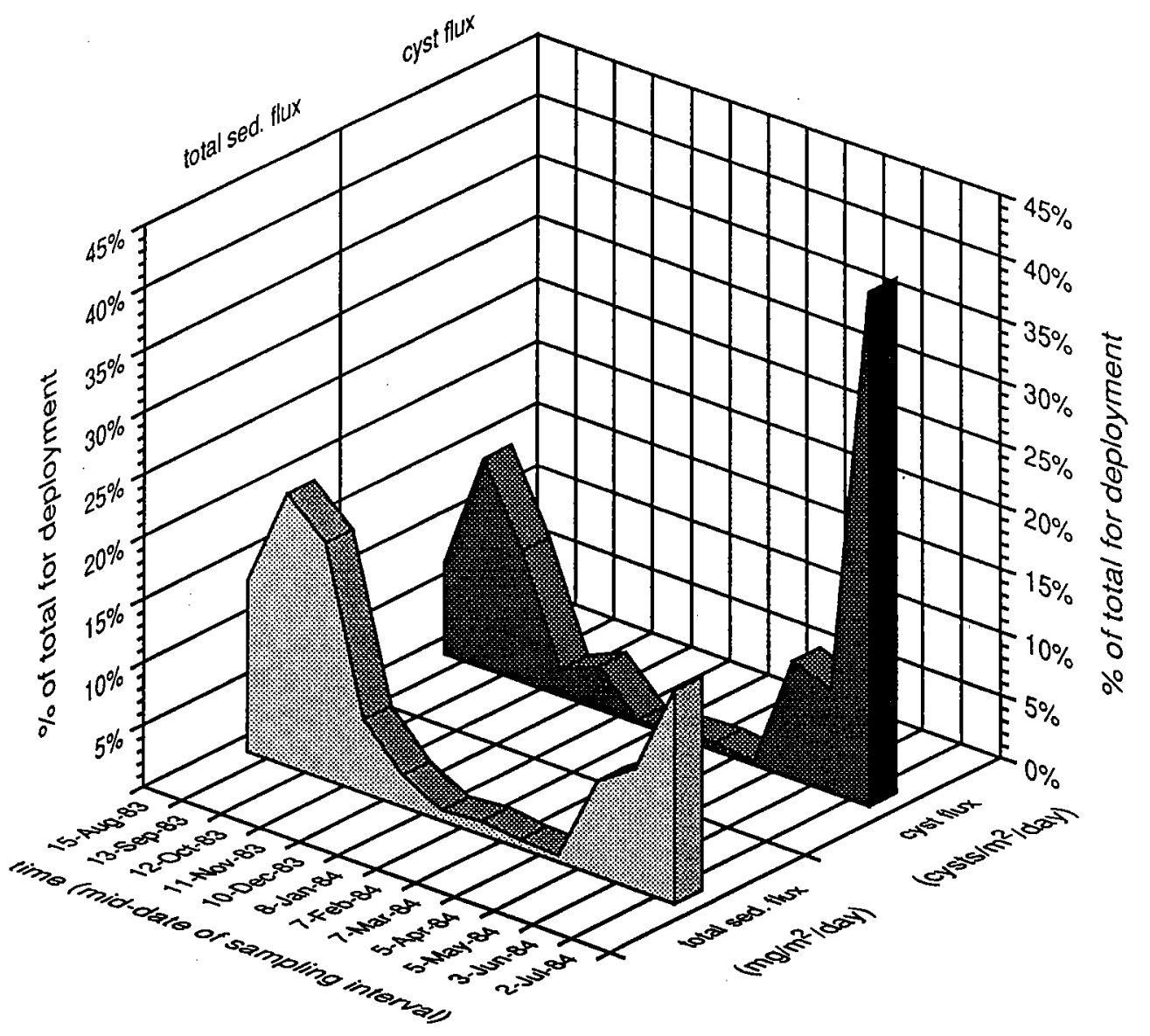

cyst flux

total sed: flux

Figure 3.9: Percentage cyst and total sediment fluxes at Lofoten Basin (LB). Correlation coefficient $(r)$ between total sediment and cyst fluxes $=0.71$. For flux values, see Table 3.4. 


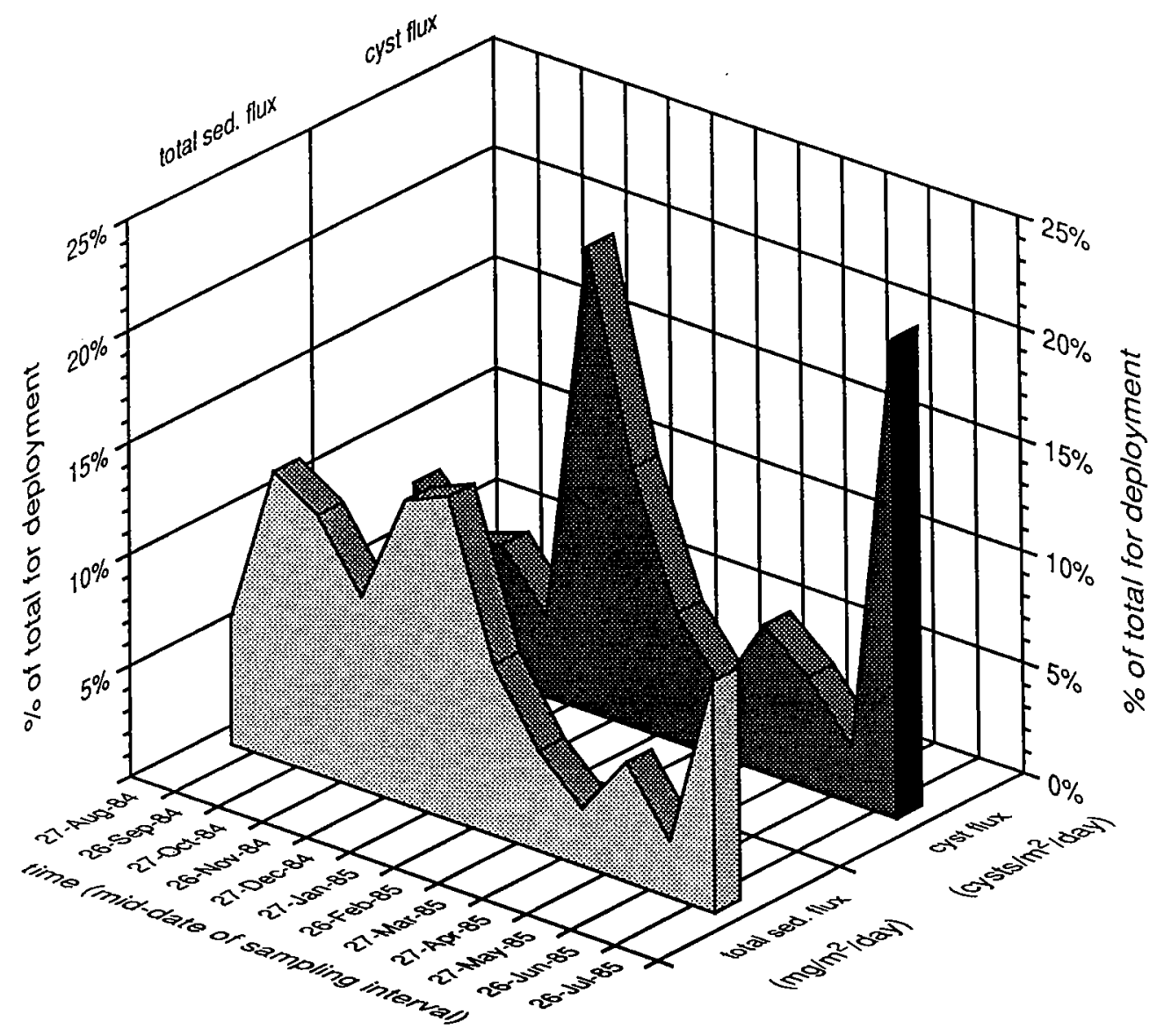

cyst flux

total sed. flux

Figure 3.10: Percentage cyst and total sediment fluxes at Bear Island Island (BI). Correlation coefficient $(r)$ between total sediment and cyst fluxes $=0.56$. For flux values, see Table 3.5 . 


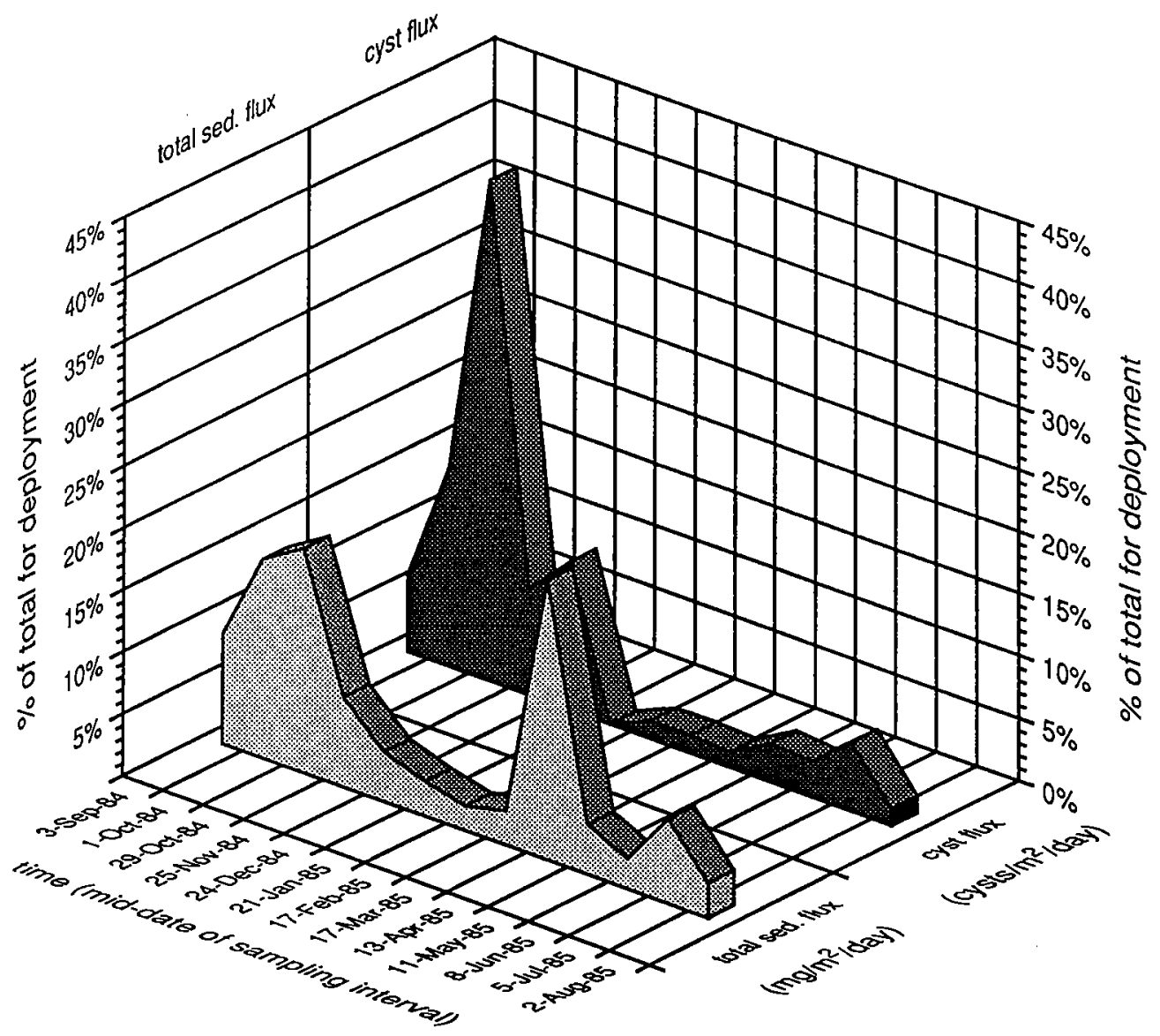

cyst flux

total sed. flux

Figure 3.11: Percentage cyst and total sediment fluxes at Fram Strait (FS). Correlation coefficient $(r)$ between total sediment and cyst fluxes $=0.54$. For flux values, see Table 3.6. 


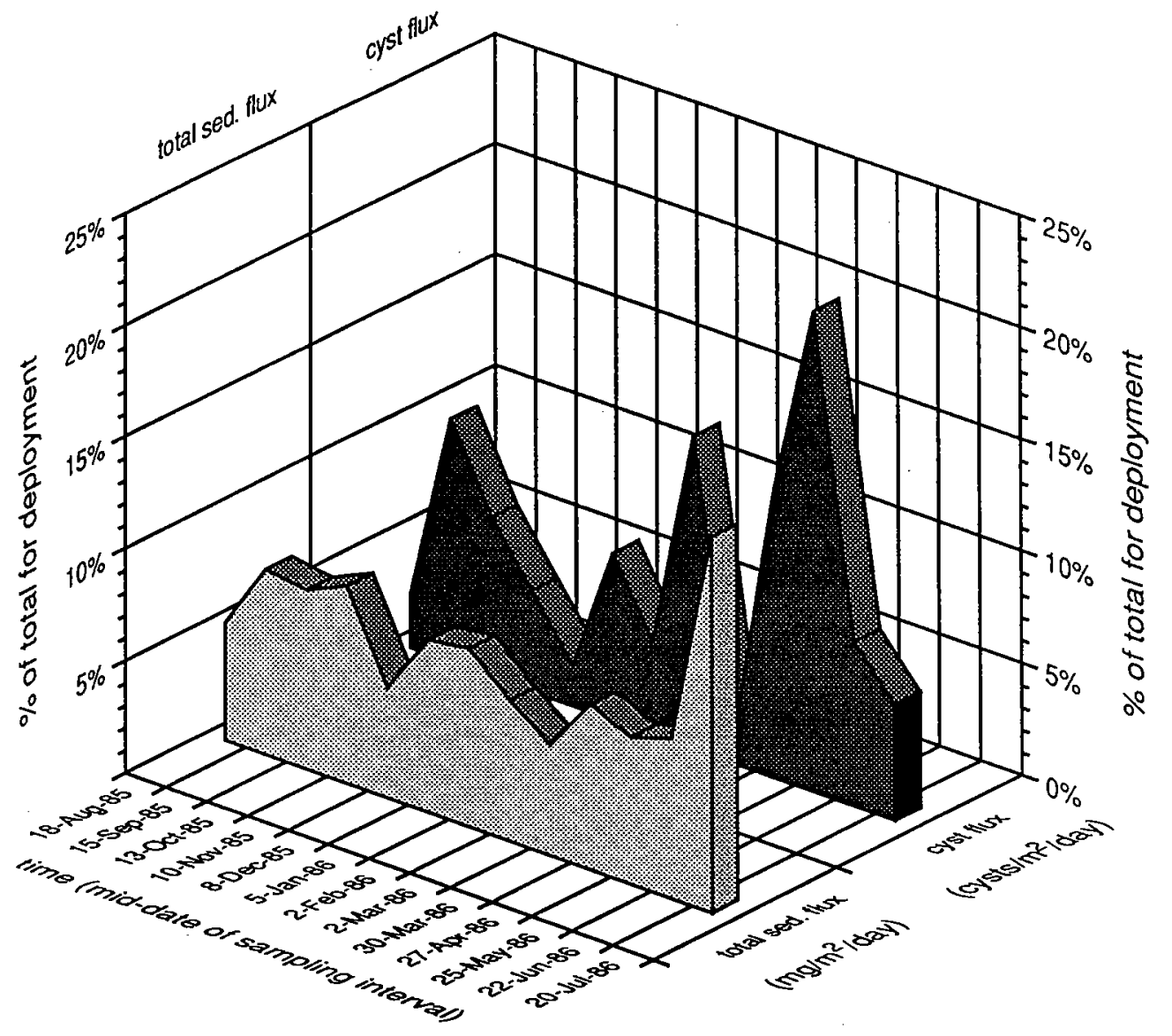

cyst flux

total sed. flux

Figure 3.12: Percentage cyst and total sediment fluxes at Greenland Basin (GB). Correlation coefficient $(r)$ between total sediment and cyst fluxes $=-0.02$. For flux values, see Table 3.7. 
Table 3.8: Comparison of average total sediment and total cyst fluxes for deep sea sediment trap stations in the Equatorial Atlantic Ocean, Central Pacific Ocean, Panama Basin, and Norwegian Atlantic and East Greenland Current regions of the Nordic Seas. Sediment fluxes are taken from Honjo et al. (1980) and Honjo et al. (1987). Total fluxes for the Atlantic and Pacific oceans, and the Panama Basin are from Dale, Chapter 1, this volume.

\begin{tabular}{|c|c|c|}
\hline $\begin{array}{c}\text { Station } \\
\text { and } \\
\text { Trap Depth } \\
\text { (m) }\end{array}$ & $\begin{array}{c}\text { Average } \\
\text { Total } \\
\text { Sed. Flux } \\
\left(\mathbf{m g} / \mathbf{m}^{2} / \text { day }\right)\end{array}$ & $\begin{array}{c}\text { Average } \\
\text { Total } \\
\text { Cyst Flux } \\
\left(\# / \mathrm{m}^{2} / \text { day }\right)\end{array}$ \\
\hline $\begin{array}{l}\text { Equatorial Atlantic: } \\
\text { S } \\
5,206\end{array}$ & 13 & 2,560 \\
\hline $\begin{array}{l}E \\
5,068\end{array}$ & 47 & 14,584 \\
\hline $\begin{array}{l}\text { Central Pacific: } \\
P_{1} \\
5,582\end{array}$ & 11 & 401 \\
\hline $\begin{array}{l}\text { Panama Basin: } \\
\text { PB }_{1} \\
3,791\end{array}$ & 180 & 2,267 \\
\hline $\begin{array}{l}\text { Nordic Seas (Norwegie } \\
\text { NA } \\
2,630\end{array}$ & $\begin{array}{l}\text { Atlantic Current): } \\
48\end{array}$ & 407 \\
\hline $\begin{array}{l}\text { LB } \\
2,761\end{array}$ & 62 & 479 \\
\hline $\begin{array}{l}\mathrm{BI} \\
1,700\end{array}$ & 78 & 445 \\
\hline $\begin{array}{l}\text { Nordic Seas (East Gre } \\
\text { FS } \\
2,442\end{array}$ & $\begin{array}{l}\text { land Current): } \\
19\end{array}$ & 151 \\
\hline $\begin{array}{l}\text { GB } \\
2,823\end{array}$ & 28 & 76 \\
\hline
\end{tabular}

between the five stations compare roughly with the ratios of total sediment fluxes, which also were notably higher for the stations influenced by the Norwegian Atlantic Current: 48,62 , and $78 \mathrm{mg} / \mathrm{m}^{2} /$ day, respectively, for $\mathrm{NA}, \mathrm{LB}$ and $\mathrm{BI}$, as compared with 19 and $28 \mathrm{mg} / \mathrm{m}^{2} /$ day, respectively, for FS and GB (Honjo et al., 1987; Table 3.8). However, the intervals during which both types of fluxes settled out of the water column did not always correlate in time. The timing of the total cyst and sediment fluxes were most closely correlated at the Lofoten Basin ( $r=0.75$; Figure 3.9), and Aegir Ridge $(r=0.71$; Figure 3.8) stations. At Bear Island, a high fall sediment flux is accompanied by a low cyst flux, and a small pulse at the May 12 - June 11, 1985, sampling interval occurs at a time when the cyst flux is in fact decreasing (Figure 3.10). Otherwise, the winter peak in cyst flux which begins during the December 11, 1984 - January 12, 1985, sampling interval and continues into the January 12 - February 11, 1985, sampling interval falls within the December 11, 1984 February 11, 1985, interval of peak total sedimentation recorded at this station (discussed below, and by Honjo et al. (1988). The coefficient of correlation (r) at Bear Island between 
total cyst and sediment flux is 0.56. A comparable correspondence is seen between cyst and sediment fluxes in the Fram Strait ( $\mathrm{r}=0.54$; Figure 3.11 ), where the total sediment and cyst flux curves are relatively similar with the exception of a peak in sediment flux during the March 30 - April 27, 1985, interval, resulting from ice melt. If the sampling interval representing ice melt is omitted from the linear regression, the coefficient of correlation increases to 0.87 .

In contrast, very little correspondence is seen between total cyst and sediment flux at the Greenland Basin station ( $\mathrm{r}=\mathbf{- 0 . 0 2}$ ), where the cyst flux occurs as periodic pulses throughout the year (Figure 3.12). Possible mechanisms influencing the cyst fluxes throughout the region are discussed below, with respect to species assemblage composition at each station.

\section{Diversity}

The total number of cyst types documented also was distinctly higher for the stations situated in the Norwegian Atlantic Current (NA: 16; LB: 16; BI 14) than for the stations influenced by the East Greenland Current (FS: 10; GB: 6). The concept of "diversity" is not straight-forward, however, in a system where cyst input can be traced to several different sources, including transport by oceanic currents, coastal input, and primary productivity (see below). The distinctive decrease in species diversity from the eastern to the western side of the basin probably reflects the different origins of the main water masses, broadly reflecting the general biological principle that species diversity decreases from warmer to colder climatic zones. The low diversity assemblages characterizing the stations influenced by the colder, East Greenland Current are comprised mainly of cold water species (Impagidinium pallidum, Multispinula minuta and undifferentiated, spherical brown protoperidinioid cysts), whereas the relatively higher diversity assemblages of the Norwegian Atlantic Current are comprised mainly of cyst types previously documented from more temperate areas along the Norwegian coast and in the North Atlantic (see Table 3.2). Coastal input and transport of cysts by oceanic currents thus probably enhances the basic pattern of species diversity, with more diverse, warmer water assemblages transported northward by the Norwegian Atlantic Current, whereas less diverse, colder water assemblages are transported southward by the East Greenland Current.

\section{Supply of Cysts}

The results clearly show systematic changes in both total cyst flux and species assemblage corresponding with changing water masses around the Nordic Sea Basin (Figure 3.13). In order to fully understand these changes, it is necessary to identify the sources of the cysts and their input to the sedimentary system. Although a detailed interpretation of this will be presented elsewhere upon completion of the study, it is important to note that, so far, three main types of cyst input have been identified: 1) produced locally in the overlying water masses; 2) transported in from adjoining areas; and 3) resedimenting of older cysts.

The species $I$. pallidum is probably the best example of a locally produced cyst type. As with other species of the genus Impagidinium (Wall et al., 1977), this species appears to be oceanic. It has never been recorded in the coastal samples which have been studied from around the basin (Figure 3.1), although it is present in all of the deep sea samples studied. Many examples were seen with intact, fresh-looking cell contents, particularly 


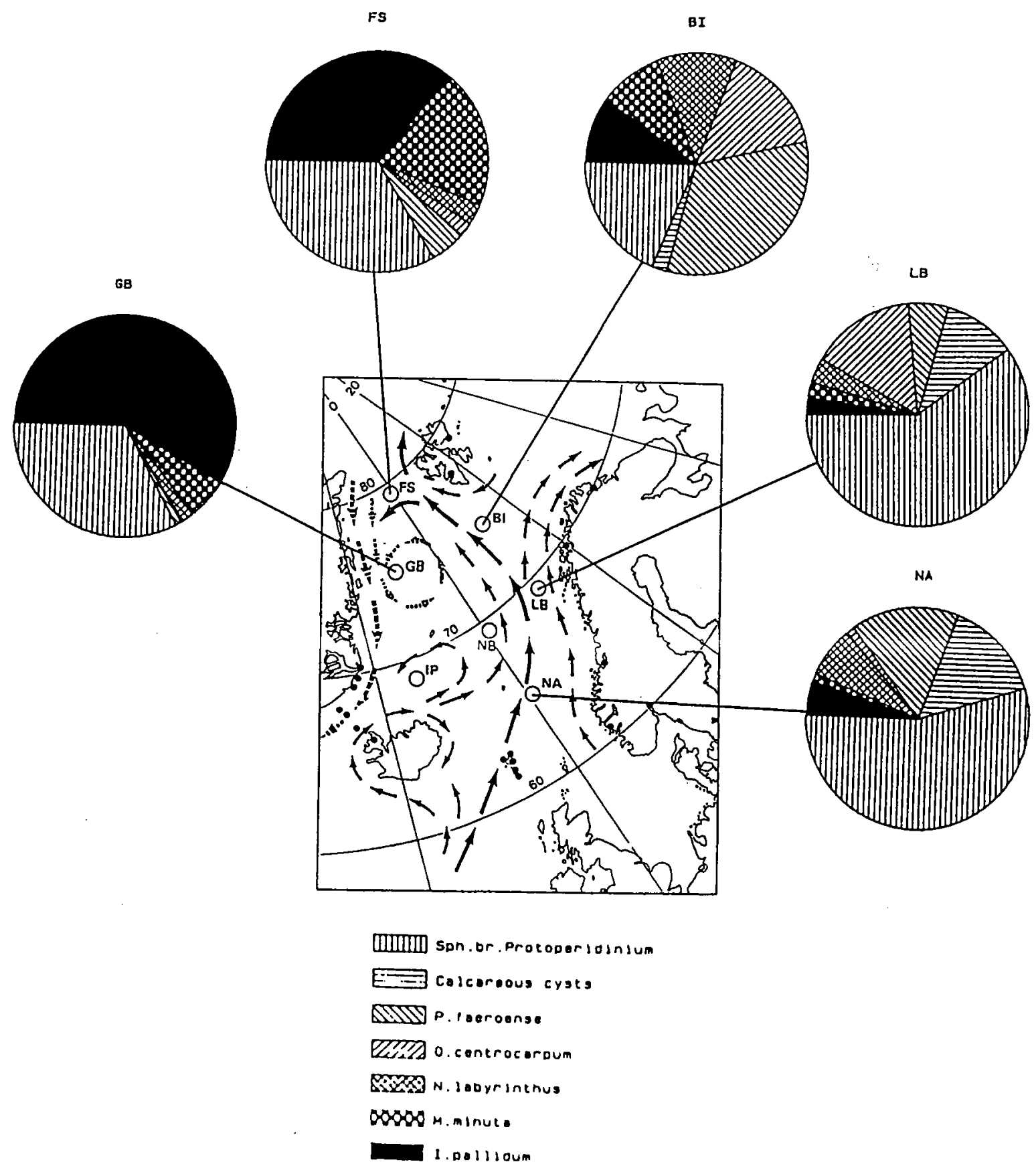

Figure 3.13: Diagram of changing cyst assemblages around the Nordic Sea Basin, including cyst types that comprised $5 \%$ or more of the assemblage at any station. 
from the Greenland Basin, where it dominated the cyst assemblage (47\%). This is the first documentation of "living" examples of what should prove to be a very useful indicator species for extremely cold oceanic waters (roughly $-1-4^{\circ} \mathrm{C}$ ). The species Nematosphaeropsis labyrinthus is the other cyst probably produced to some extent locally, based on its outerneritic to oceanic distribution worldwide.

Most of the other cysts are considered to be most likely transported from adjoining areas by one of several different pathways. At least one cyst type, the calcareous cysts, is most likely transported into the region from oceanic North Atlantic waters. This is strongly suggested by the fact that it has been documented previously only from the warmer oceanic gyres (Dale, this volume), and its distribution here follows the warmer Norwegian Atlantic Current in diminishing amounts northwards (Table 3.2, Figure 3.13). None of the other species are considered to be oceanic species, based on current knowledge of their distributions. Their distributions in the deep sea, here, correspond with their known distributions in nearby coastal and shelf environments. This does not prove that they are transported from these sources, but there is evidence that at least some are. For example, an anomalous pulse of one cyst species, Peridinium faeroense, corresponded with an unusually high rate of sedimentation during the December 11, 1984 to January 12, 1985, sampling interval at the Bear Island station. This pulse contained $21 \%$ of the total cyst flux for the deployment, followed by $12 \%$ during the January 12 to February 11, 1985, sampling interval (Table 3.5, Figure 3.4). This anomalous cyst spike corresponded with a sharp increase in fine grained, organic-rich lithogenic matter, which almost certainly included most of the cysts. A total of $29 \%$ of the sediment flux, and $33 \%$ of the cyst flux for the entire deployment was deposited between December 11, 1984 and February 11, 1985. According to Honjo et al. (1988), this pulse was caused by a density flow displacing a reservoir of loosely consolidated sediments from the nearby Barents Shelf.

A dramatic example of resedimentation of older cysts was recorded from the Lofoten Basin station during the June-July, 1984, sampling intervals. A cyst flux of 2,358 cysts/ $\mathrm{m}^{2} /$ day, $41 \%$ of the total for the deployment, occurred between July 2 and August 1, 1984, and this was accompanied by a flux of recycled pre-Quaternary cysts of $2,358 / \mathrm{m}^{2} /$ day (Figure 3.14), or $99 \%$ of the total recycled pre-Quaternary cyst flux seen at this station. The remaining $1 \%$ occurred during the previous sampling interval, between June 3 and July 2, 1984. This was the only flux of recycled pre-Quaternary cysts recorded in the entire investigation. The pre-Quaternary assemblage was dated to Early Miocene, and since Early Miocene sediments are known to occur on the Lofoten Shelf (Mokhtari et al., 1987), this points to resuspension of nearby slope sediments as a probable result of turbidity flow. This event probably began during the latter part of the June 3-July 2, 1984, interval, with the majority of resuspended matter reaching the depth of sediment trap during the July 2August 1, 1984, interval. This may possibly have been triggered by an earth tremor of greater than average magnitude for the area reported by Norwegian and Russian authorities on June 22,1984 . The fact that 1 ) the highest flux of recent cysts of the entire deployment occurred during the same sampling interval as the recycled cyst pulse (Figure 3.14), and 2) many of the cyst types documented at the station are known coastal and neritic forms, strongly suggests that the turbidity flow carried with it a higher than normal number of recent cysts in addition to the recycled. 


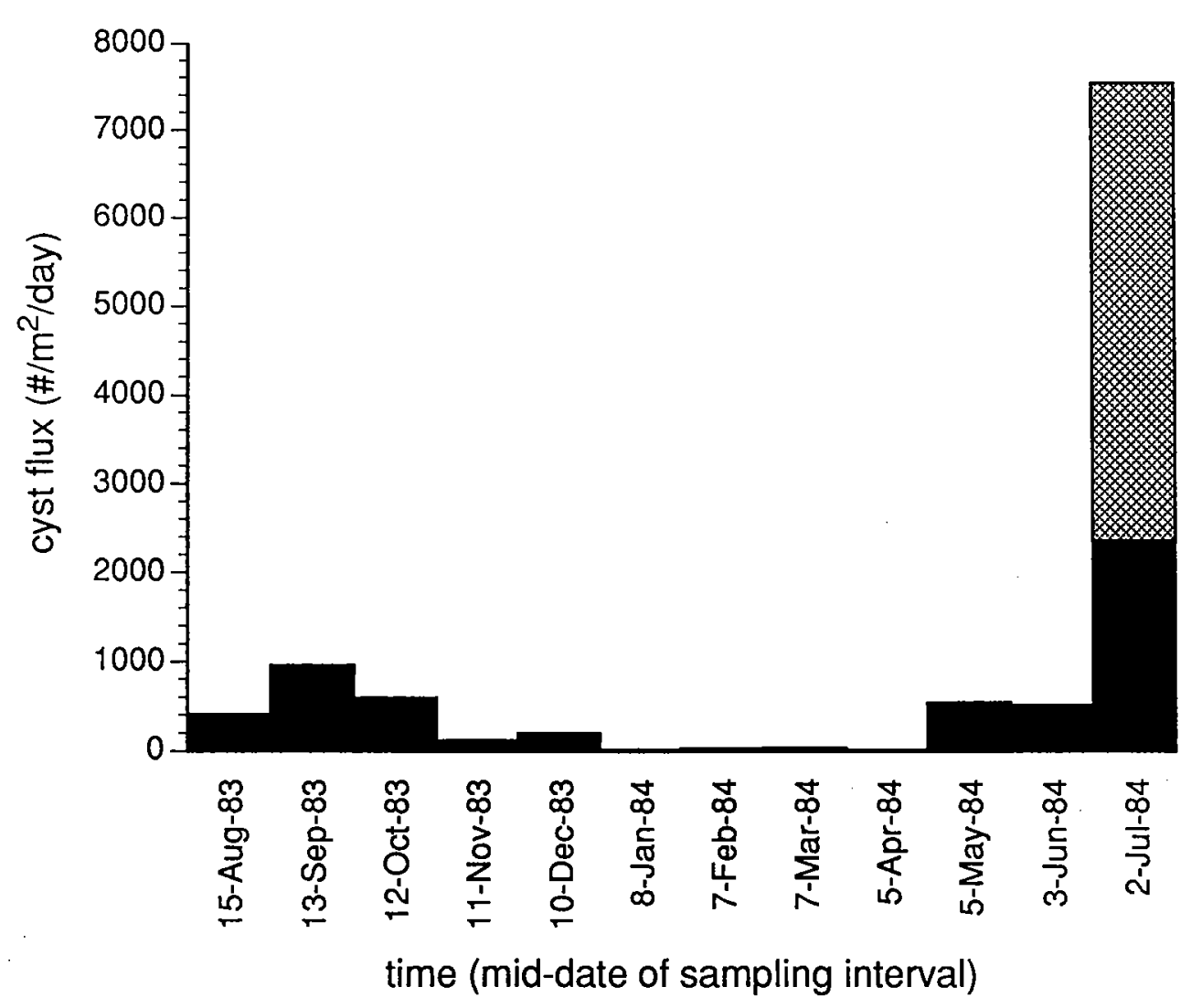

recycled pre-Quaternary cysts recent cysts

Figure 3.14: Cyst distribution at the Lofoten Basin station, showing sudden pulse of recycled pre-Quaternary (mainly Early Miocene) cysts in the July 2-August 1, 1984, interval. 
Table 3.9: Correlation matrix of Pearson's Product Moment correlation coefficients for 5 sediment trap stations in the Nordic Seas, based on the percentage composition of their dinoflagellate cyst assemblages. $\mathrm{NA}=$ Aegir Ridge, $\mathrm{LB}=$ Lofoten Basin, $\mathrm{BI}=$ Bear Island, $\mathrm{FS}=$ Fram Strait, and GB = Greenland Basin. (For locations, see Figure 3.1).

\begin{tabular}{|llllll|}
\hline \hline & & & & & \\
& & & & & \\
\hline & & & & & \\
NA & 1.00 & & & & \\
LB & 0.94 & 1.00 & & & \\
BI & $\mathbf{0 . 5 4}$ & 0.49 & 1.00 & & \\
FS & $\mathbf{0 . 5 8}$ & 0.58 & 0.47 & 1.00 & \\
GB & $\mathbf{0 . 4 4}$ & 0.42 & 0.31 & 0.92 & 1.00 \\
\hline
\end{tabular}

\section{Comparisons Between Stations}

Overall assemblage similarities between stations can be summarized by the correlation matrix shown in Table 3.9, which is based on the species \% of total cyst flux recorded at each station. The assemblage composition at the Lofoten Basin and Aegir Ridge stations from the Norwegian Atlantic Current were most similar $(r=0.94)$, followed closely by a high degree of similarity between the Fram Strait and Greenland Basin stations of the East Greenland Current $(r=0.92)$. In contrast, the assemblage at the Bear Island station did not correlate highly with that of any of the other stations, although it was slightly more correlated with the Aegir Ridge and Lofoten Basin stations of the Norwegian Atlantic Current ( $\mathrm{r}=0.54$ and 0.49 , respectively) than for the Fram Strait or Greenland Basin stations of the East Greenland Current ( $r=0.47$ and 0.31 , respectively). This probably reflects its location at the northernmost extension of the Norwegian Atlantic Current, where it receives input also from the western Barents Sea.

Assemblage relationships between all five stations are shown in the cluster diagrams in Figure 3.15. This shows that Cluster 1 identifies the most important species accounting for the close correlation between the Greenland Basin and Fram Strait stations: Impagidinium pallidum (here suggested to be an extremely cold water, oceanic species) and Multispinula minuta (already established in the literature as an important arctic indicator species). Cluster 3 includes the important species for the Aegir Ridge and Lofoten Basin stations, with calcareous cysts (here suggested to be transported in from North Atlantic oceanic waters), and others considered to be most likely transported from nearby shelf areas. 

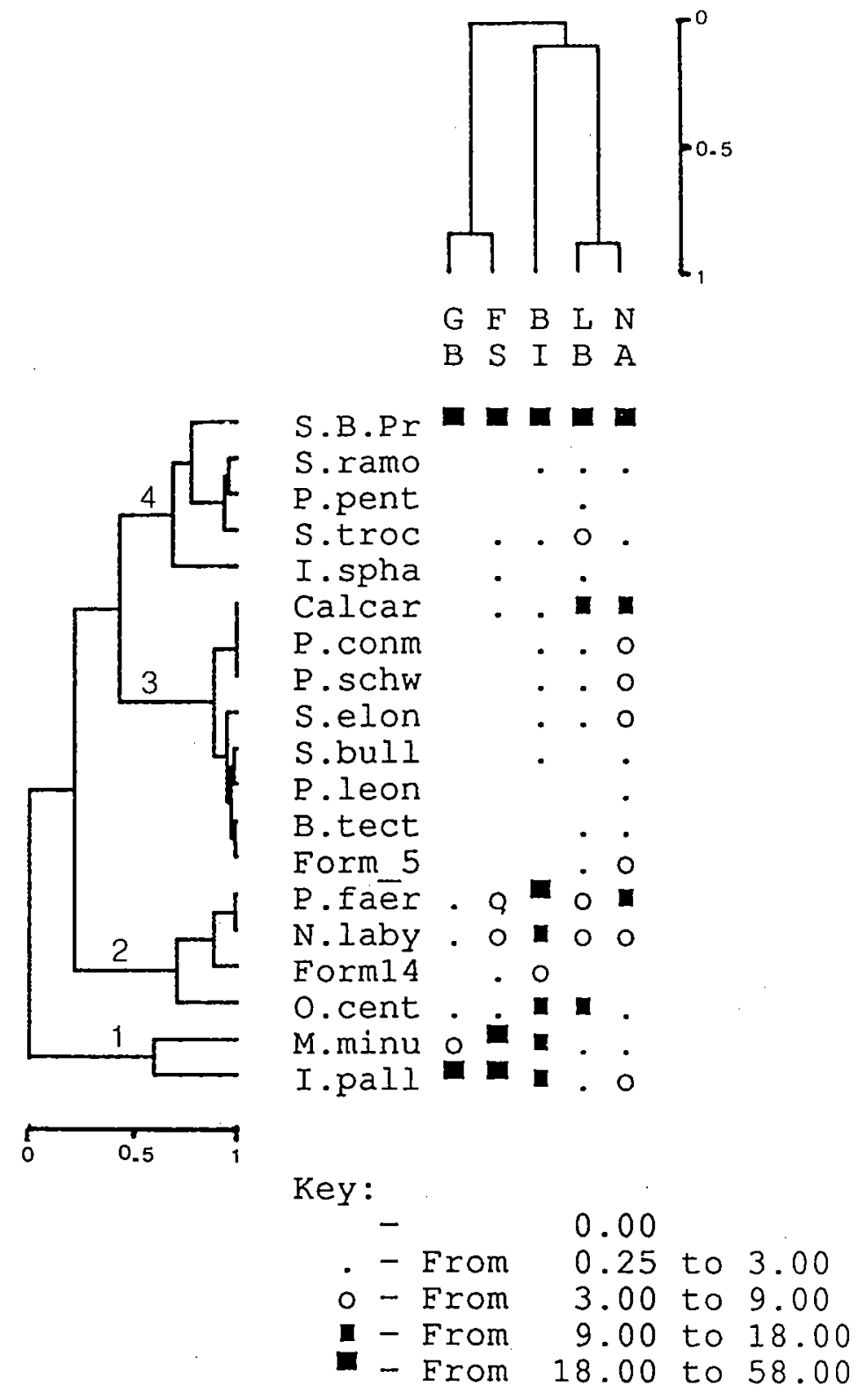

Figure 3.15: Cluster dendrograms using Pearson Product Moment correlation coefficients for 19 cyst types at 5 stations in the Nordic Seas, plotted together with schematic representation of percentage abundance data. Scale of similarity from 0 (lowest) to 1 (highest). NA = Aegir Ridge; LB = Lofoten Basin; BI = Bear Island; FS = Fram Strait; GB = Greenland Basin. Key indicates \% abundance. 


\section{Comparisons Between Regions}

Comparison with the only previous study of dinoflagellates from sediment traps in other regions (Equatorial Atlantic, Central Pacific, and Panama Basin; Dale, Chapter 1, this volume) is hindered somewhat by differences in sampling intervals. Deployments in the other regions ranged from 2 to slightly less than 4 months, whereas the Nordic Seas deployments ranged from roughly 10 months to 1 year in duration. However, because the other regions are not affected by strong seasonal variations, average daily fluxes based on just a part of the year are likely to be reasonably representative.

Cyst fluxes differed markedly in both composition and amount between the high latitude region of the Nordic Seas and the lower latitude stations in the other regions. Whereas calcareous cysts accounted for $82 \%$ to $100 \%$ of the total cyst flux recorded in these other regions, they never accounted for more than $12 \%$ of the total cyst flux at the Nordic Sea stations, and even these were considered to have been transported from the North Atlantic. This difference is believed to reflect differences in the overlying water masses, and in the production and transport of cysts. The predominance of calcareous cysts in the other regions represents local cyst production from truly oceanic species, whereas the only truly oceanic species in the Nordic Seas produce organic-walled cysts (Impagidinium pallidum and Nematosphaeropsis labyrinthus). In addition, the stations in the smaller Nordic Seas Basin are significantly closer to the continental margins, from which they receive a significant contribution to the deep sea cyst flux. Thus, whereas the cyst fluxes in the other regions consisted primarily of an open ocean signal, characterized by calcareous cysts, the cyst fluxes in the Nordic Seas contained both an open ocean and a coastal component, both of which were reflected primarily by organic-walled cysts.

Total cyst fluxes in the other regions were much greater than those of the Nordic Seas (Table 3.8). However, total sediment fluxes were generally higher in the Nordic Seas than in the other regions, with the exception of the Panama Basin, which was markedly higher than any of the other stations due to its location nearer to a continental land mass (Honjo et al., 1982). However, of particular interest to the discussion here is the generally good correspondence between the ratios of total sediment flux to total cyst flux among stations in both the Nordic Seas and the other regions. On first consideration this would seem somewhat anomalous, given our conclusions that much of the cyst flux in the Nordic Seas is transported in, whereas that of the other regions is more locally produced. When the composition of these sediments is taken into account, however, these results are consistent with our conclusions. The sediment flux in the Equatorial Atlantic and Central Pacific oceans is more than $90 \%$ biogenic, that is, produced in the overlying waters, whereas sediments collected from the Nordic Seas were only 40 to $75 \%$ biogenic material, the remainder being of lithogenic or likely transported origin (Honjo et al., 1982; 1987). This supports our general conclusion that the cyst and total sediment fluxes are more closely coupled to mechanisms of transport within the Nordic Seas Basin, but to local production at the lower latitude stations. 


\section{Summary and Conclusions}

1. Dinoflagellate cyst assemblages sedimenting out in the Nordic Seas were overwhelmingly dominated by organic walled forms, with calcareous forms contributing only a small percentage of the total cyst flux. This contrasts sharply with the cyst signal previously recorded from the Equatorial Atlantic, Central Pacific and the Panama Basin, which consisted almost entirely of calcareous forms.

2. Cyst fluxes changed systematically with changing water masses around the Nordic Seas Basin. Fluxes were distinctly higher for stations influenced by the relatively warmer, Norwegian Atlantic Current that for stations influenced by the relatively colder East Greenland Current: $407-479$ cysts $/ \mathrm{m}^{2} /$ day, compared with $76-151 \mathrm{cysts} /$ $\mathrm{m}^{2} /$ day, respectively.

3. Cyst diversity ranged from 14 to 16 species recorded for stations located in the Norwegian Atlantic Current, whereas from 6 to 10 species were recorded at stations located in the East Greenland Current. Spherical brown protoperidinioid cysts were the dominant cyst type for the region as a whole. Spherical calcareous cysts, Polykrikos schwartzii, Protoperidinium americanum, P. conicum, P. pentagonum, Spiniferites bulloideus, $S$. elongatus, $S$. ramosus, and Form 5 were typical for assemblages influenced by the Norwegian Atlantic Current, whereas Impagidinium pallidum and Multispinula minuta were typical for assemblages of the East Greenland Current.

4. Sources of cyst input included: 1) local cyst production, 2) cyst transport, and 3) resuspension of older material from adjacent shelves. Impagidinium pallidum and $\mathrm{Ne}$ matosphaeropsis labyrinthus are believed to be produced locally by oceanic species. Spherical calcareous cysts are warmer water oceanic species considered to have been transported from the North Atlantic. Most of the other forms are considered to have been transported from nearby continental margins. The Early Miocene cysts at the Lofoten Basin station were probably resuspended from the nearby continental slope.

5. These results suggest that dinoflagellate cysts should prove to be very useful tracers of water masses and sediment transport within the Nordic Sea region. Results from the remaining two stations in this study, (IP and NB, Figure 3.1) and from one deployment recently recovered from the Western Barents Sea, should eventually help to strengthen this emerging potential for using cysts as paleoecological indicators in the fossil record.

\section{Acknowledgements}

This work was only made possible through close cooperation with Dr. Susumu Honjo, Woods Hole Oceanographic Institution, who kindly provided the samples and background data from the region. Our thanks also to Steve Manganini, for his help in all phases of the sediment trap deployments, transport of samples, etc., and to the many U.S. and German colleagues, too numerous to name, whose professional skill both in executing the sediment trap deployments and in the laboratory made this investigation possible. Our thanks also 
to Anne Edwards for her careful and skilled technical assistance in the publishing of this volume. A.L. Dale wishes to gratefully acknowledge support from a fellowship awarded by the American Scandinavian Foundation, and the use of working space and laboratory facilities provided by the University of Oslo Department of Geology. Many of the coastal samples around the basin, used for general comparison with the deep sea sediment trap samples, were analyzed by Nils Gundersen and Atle J. Scholze, while employed on a research grant to B. Dale (Project 1118, British Petroleum Development of Norway A.S. and B.P. International Ltd., U.K.).

\section{References}

Dale, B. (1986). Life cycle strategies of oceanic dinoflagellates. UNESCO Technical Papers in Marine Science, 49: 65-72.

Dietrich, G. (1969). Atlas of the Hydrography of the Northern North Atlantic: Based on the Polar Front Survey of the International Geophysical Year Winter and Summer 1958. Compiled by G. Dietrich, issued by Conseil International pour l'Exploration de la Mer, Service Hydrographique, Copenhagen, Denmark, 144 pp.

Harland, R., P.C. Reid, P. Dobell and G. Norris (1980). Recent and sub-Recent dinoflagellate cysts from the Beaufort Sea, Canadian Arctic. Grana, 19: 211-225.

Honjo, S. and K.W. Doherty (1988). Large aperture time-series sediment traps: design objectives, construction, and application. Deep-Sea Research, 35: 133-149.

Honjo, S., S.J. Manganini and G. Wefer (1988). Annual particle flux and a winter outburst of sedimentation in the northern Norwegian Sea. Deep-Sea Research, 35: 1223-1234.

Honjo, S., S. Manganini, A. Karowe and B. Woodward (1987). Particle Fluxes, Northeastern Nordic Seas: 1983-1986. In: Nordic Seas Sedimentation Data File, Woods Hole Oceanographic Institution Technical Report WHOI-87-17, vol. 1

Honjo, S., S.J. Manganini and J.J. Cole (1982). Sedimentation of biogenic matter in the deep ocean. Deep-Sea Research, 29: 609-625.

Johannessen, O.M. (1986). Brief overview of the physical oceanography. In: The Nordic Seas, B.G. Hurdle (ed.), Springer-Verlag, NY, 777 pp.

Kellog, T.B. (1973). Late Quaternary climatic changes in the Norwegian and Greenland seas. In: Climate of the Arctic, G. Weller and S.A. Bowling (eds.), Geophysical Institute, University of Alaska, $436 \mathrm{pp}$.

Mokhtari, M., S. Markvard and I. Olafsson (1987). Seismic Study of Lofoten Continental Margin, N. Norway. Seismol. Obsv., Univ. Bergen, Seismo-Ser., X: 3-14.

Wall, D., B. Dale, G.P. Lohmann and W.K. Smith (1977). The environmental and climatic distribution of dinoflagellate cysts in modern marine sediments from regions in the North and South Atlantic oceans and adjacent seas. Marine Micropaleontology, 2: 131-200. 


\section{Plate}




\section{PLATE 3.1}

Light photomicrographs of dinoflagellate cysts from the Nordic Seas.

1-4 Impagidinium pallidum, with cell contents, from Greenland Basin (GB) station. 1-2: $42 \times 37 \mu \mathrm{m} ; 3-4: 40 \mu \mathrm{m}$.

5, 6 Multispinula minuta from Bear Island (BI) station. $48 \times 45 \mu \mathrm{m}$.

7, 8 Protoperidinium conicoides from Lofoten Basin (LB) station. Note archeopyle in figure $7.47 \times 45 \mu \mathrm{m}$.

9 Nematosphaeropsis labyrinthus, with cell contents, from Fram Strait (FS) station. $45 \times 42 \mu \mathrm{m}$.

10 Form 14 from Bear Island (BI) station. $37 \times 30 \mu \mathrm{m}$.

11, 12 Protoperidinium americanum from Lofoten Basin (LB) station. $38 \mu \mathrm{m}$.

13 Protoperidinium conicum from Lofoten Basin (LB) station. $65 \times 58 \mu \mathrm{m}$.

14 Protoperidinium leonis from Aegir Ridge (NA) station. $68 \times 35 \mu \mathrm{m}$.

15 Protoperidinium pentagonum from Lofoten Basin (LB) station. $88 \times 68 \mu \mathrm{m}$.

16 Scrippsiella trochoidea from Lofoten Basin (LB) station. $33 \mu \mathrm{m}$.

17, 18 Spherical calcareous cyst from Lofoten Basin (LB) station. Note archeopyle in figure 18. $55 \mu \mathrm{m}$.

19 Form 5 from Aegir Ridge (NA) station. $25 \mu \mathrm{m}$.

20 Spiniferites elongatus from Aegir Ridge (NA) station. $56 \times 43 \mu \mathrm{m}$.

Note that dimensions are given in length $\times$ width (or diameter if spherical) of the central body. 


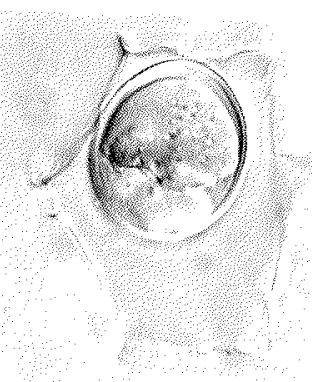

1

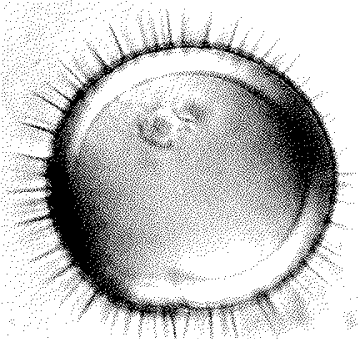

5
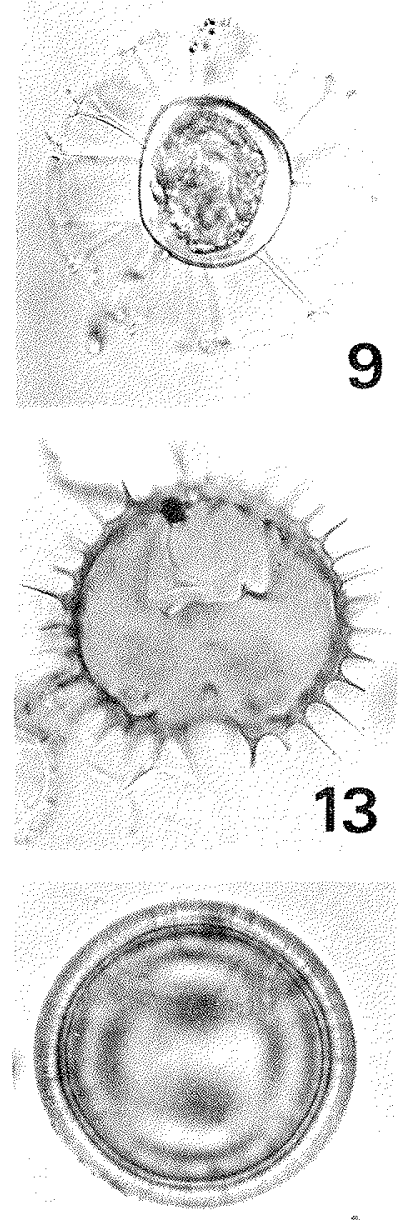

17
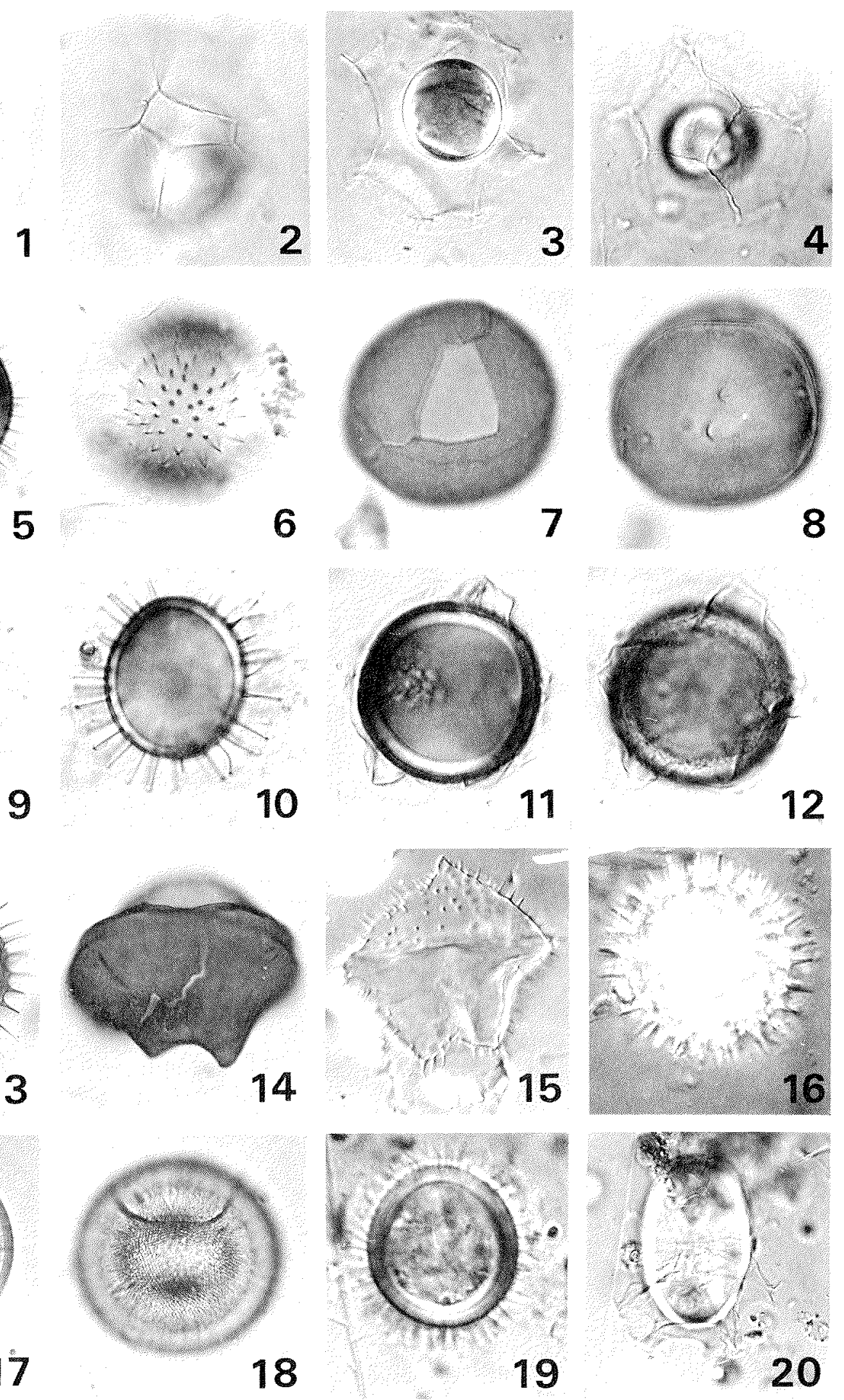


\title{
Ocean Biocoenosis Series
}

\author{
Edited by Susumu Honjo
}

No. 1 - Steinmetz, John C., Calcareous Nannoplankton Biocoenosis: Sediment Trap Studies in the Equatorial Atlantic, Central Pacific, and Panama Basin. 1991. (85 pp., 22 pls.) ............................\$10.00

No. 2 - Takahashi, Kozo, Silicoflagellates and Actiniscus: Vertical Fluxes at Pacific and Atlantic Sediment Trap Stations. 1991. (35 pp., 2 pls.) .....\$10.00

No. 3 - Takahashi, Kozo, Radiolaria: Flux, Ecology, and Taxonomy in the Pacific and Atlantic. 1991. (303 pp., 63 pls.) ................... $\$ 35.00$

No. 4 - Ling, Hsin Yi, Tintinnids: A Taxon-vertical Distributional Study of Settling Assemblages from the Panama Basin. 1992. (21 pp., 2 pls.) ......\$10.00

No. 5 - Dale, Barrie and Amy L. Dale, Dinoflagellate Contributions to the Deep Sea 1992. (75 pp., 6 pls.) ......................... $\$ 10.00$

Published by:

Woods Hole Oceanographic Institution

Woods Hole, Massachusetts 02543

U.S.A.

Available from:

Office of the Research Librarian

Woods Hole Oceanographic Institution

Woods Hole, Massachusetts 02543

U.S.A. 